\title{
QUALIDADE OPERACIONAL DA FENAÇÃO: ANÁLISE DO PROCESSO DE PRODUÇÃO
}

\author{
RODRIGO GIACOMINI BONATO
}

Dissertação apresentada à Escola Superior de Agricultura "Luiz de Queiroz", Universidade de São Paulo, para obtenção do título de Mestre em Agronomia, Área de Concentração: Máquinas Agrícolas.

\footnotetext{
PIRACICABA

Estado de São Paulo - Brasil

Agosto - 2004
} 


\title{
QUALIDADE OPERACIONAL DA FENAÇÃO: ANÁLISE DO PROCESSO DE PRODUÇÃO
}

\section{RODRIGO GIACOMINI BONATO \\ Engenheiro Agrônomo}

Orientador: Prof. Dr. MARCOS MILAN

\begin{abstract}
Dissertação apresentada à Escola Superior de Agricultura "Luiz de Queiroz", Universidade de São Paulo, para obtenção do título de Mestre em Agronomia, Área de Concentração: Máquinas Agrícolas.
\end{abstract}

PIRACICABA

Estado de São Paulo - Brasil

Agosto - 2004 


\section{Dados Internacionais de Catalogação na Publicação (CIP) DIVISÃO DE BIBLIOTECA E DOCUMENTAÇÃO - ESALQ/USP}

Bonato, Rodrigo Giacomini

Qualidade operacional da fenação: análise do processo de produção /

Rodrigo Giacomini Bonato. - Piracicaba, 2004.

$100 \mathrm{p}$.

Dissertação (Mestrado) -- Escola Superior de Agricultura Luiz de Queiroz, 2004.

Bibliografia.

1. Controle estatístico do processo 2. Fenação 3. Mecanização agrícola 4. Qualidade total I. Título

CDD 658.562 


\section{Dedico,}

Aos meus pais: José Carlos Bonato e Denise Maria Giacomini Bonato, pelo constante apoio, incentivo e reconhecimento. Minha eterna gratidão.

Aos meus irmãos: Marcelo e Gabriel, pela alegria da convivência familiar.

À Juliana Ferreira Matsuoka, pelo amor e cumplicidade, pela compreensão nos momentos de ausência e pelo companheirismo. Meu reconhecimento e eterno carinho. 


\section{AGRADECIMENTOS}

À Escola Superior de Agricultura Luiz de Queiroz e seu qualificado corpo docente, pelos anos de aprendizado técnico e por me ensinar o verdadeiro sentido da palavra "companheirismo".

Ao orientador e, acima de tudo, amigo Prof. Dr. Marcos Milan. Sua dedicação à ESALQ, ética e valores serviram de exemplos na construção de minha personalidade profissional e, seus conselhos pessoais, com certeza me direcionaram em momentos difíceis.

Aos professores e funcionários do Departamento de Engenharia Rural, pelo convívio gratificante em todos estes anos.

Aos professores Nussio, Casemiro e Malcon pela orientação e aperfeiçoamento deste trabalho. 
À Fazenda Água Comprida pela confiança no trabalho de um jovem profissional. O apoio e incentivo desta empresa durante meus estudos de graduação e de pós-gradução foi extremamente valioso. Agradeço ao Sr. Isio Bacaleinick por seu exemplo de sobriedade, ao Sr. Paulo Toledo por sua confiança e reconhecimento e ao Sr. Marcos Fernando pela amizade e total apoio. Agradeço também aos demais funcionários: José Carlos, Ronildo, Ivone, Gevaldo, Márcia, Neusa, Regina e todos os tratoristas.

Aos novos amigos que fiz na John Deere Brasil, com os quais aprendo diariamente e, em especial ao Sr. Marcelo Lopes, pela motivação para finalização desta dissertação e pela confiança profissional.

Acredito que em certos momentos da vida surgem pessoas decisivas ao nosso sucesso. Agradeço a todos que direta ou indiretamente proporcionaram meu crescimento acadêmico, profissional e pessoal.

Por fim, agradeço a DEUS e a Nossa Senhora por alicerçarem minhas atitudes. 


\section{SUMÁRIO}

\section{Página}

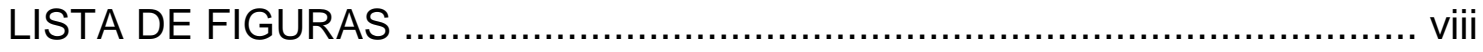

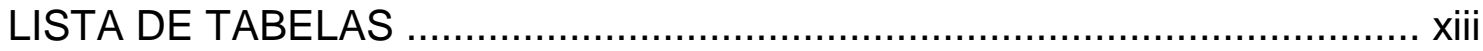

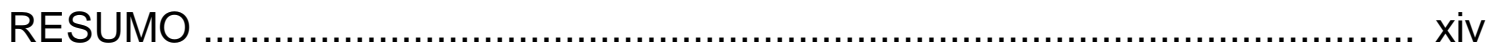

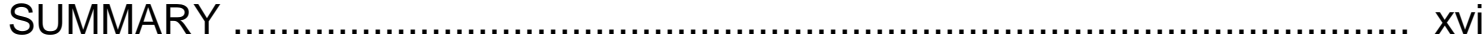

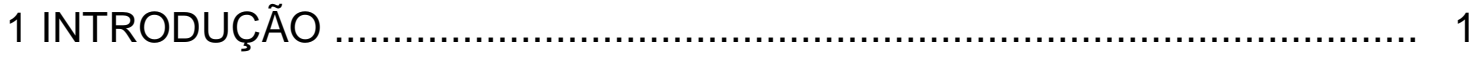

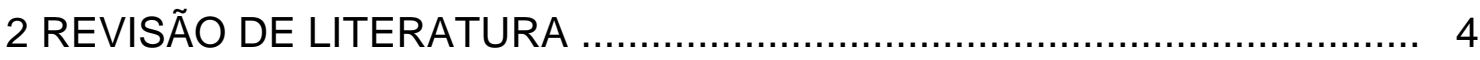

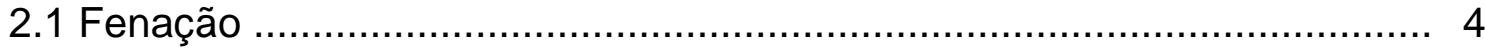

2.1.1 Descrição e importância .............................................................. 4

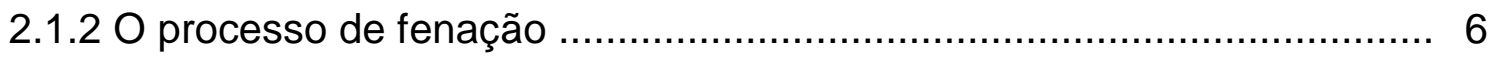

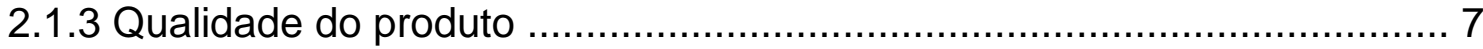

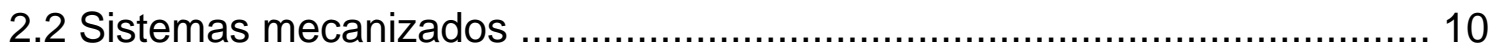

2.2.1 Desempenho operacional e econômico de sistemas mecanizados ........10

2.2.2 Determinação dos custos diretos e operacionais ................................ 12

2.2.3 Avaliação de sistemas de produção de feno ....................................... 13

2.3 Controle da qualidade em processos produtivos ................................... 14

2.3.1 Histórico da qualidade .................................................................. 14

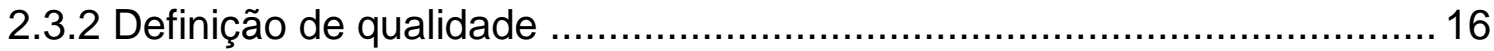

2.3.3 O controle estatístico de processos (CEP) …................................... 17

2.3.4 Conceitos do controle estatístico de processos (CEP) ......................... 19

2.3.5 Controle da qualidade na agricultura ............................................ 24

2.3.6 Controle de qualidade em operações agrícolas mecanizadas ............... 26

2.4 Agricultura de precisão e instrumentação ............................................. 29 
3 MATERIAL DE MÉTODOS

3.1 Caracterização do local do trabalho e do sistema de produção avaliado .. 32

3.2 Identificação das operações críticas 34

3.2.1 Caracterização do desempenho operacional e econômico do sistema mecanizado de fenação

3.2.2 Avaliação da qualidade das operações agrícolas mecanizadas ............. 36

3.3 Avaliação da qualidade das operações críticas ....................................... 36

3.4 Desenvolvimento de eletrônica embarcada para controle dos indicadores de qualidade na operação de enfardamento

3.4.1 Desenvolvimento de sistema eletrônico de contagem dos ciclos de prensagem dos fardos

3.4.2 Desenvolvimento do sistema eletrônico de contagem com introdução do GPS 43

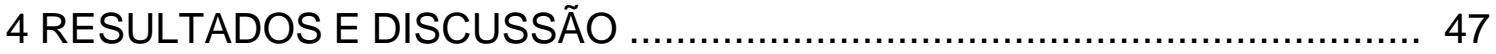

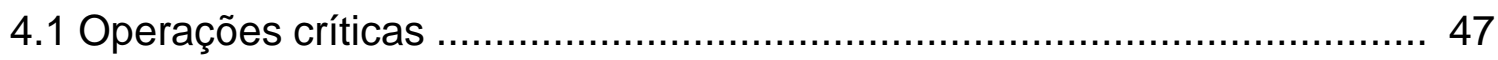

4.1.1 Desempenho operacional e econômico do sistema mecanizado ........... 47

4.1.2 Avaliação da qualidade das operações mecanizadas de fenação .......... 50

4.2 Avaliação da qualidade das operações críticas ........................................ 51

4.2.1 Avaliação da qualidade da operação de sega ....................................... 51

4.2.2 Avaliação da qualidade da operação de enfardamento ......................... 56

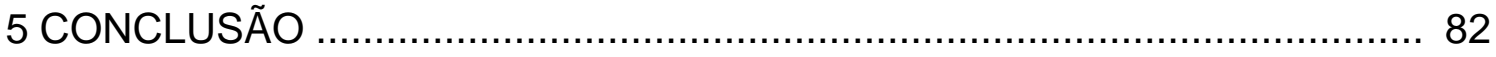

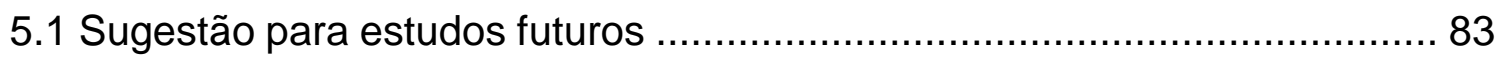

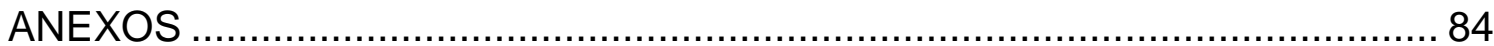

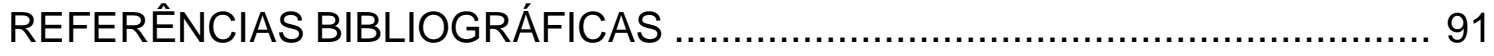




\section{LISTA DE FIGURAS}

Página

1 Fluxograma da seqüência de sub-operações realizadas na fenação 33

2 Vista lateral da enfardadora instrumentada, onde pode ser visualizado seu motor e sistema recolhedor

3 Vista da leira e sistema alimentador da enfardadora Freeman 270

4 (A) Vista externa do local de instalação do sensor de contagem dos ciclos da prensa na enfardadora Freeman; (B) Vista interna do local de instalação do sensor de contagem

5 Vista do local de instalação do sensor de "reset" no sistema de amarração da enfardadora

6 Módulo de processamento do sistema eletrônico de contagem dos ciclos de prensagem e antena do GPS

7 Gráfico dos custos operacionais dos equipamentos para as sub-operações de fenação, de acordo com as condições atuais do sistema mecanizado ... 49 
8 (A) Gráfico de controle para a média e amplitude de altura de corte da segadora Khun GMD 300; (B) Gráfico de controle da amplitude; (LSC: Limite Superior de Controle; LIC: Limite Inferior de Controle; LSE: Limite Superior de Especificação; LIE: Limite Inferior de Especificação)

9 Histograma da distribuição da altura de corte - segadora Khun GMD300 .. 53

10 Gráfico de controle para a média e amplitude de altura de corte da segadora Case 8850; (LSC: Limite Superior de Controle; LIC: Limite Inferior de Controle; LSE: Limite Superior de Especificação; LIE: Limite Inferior de Especificação)

11 Histograma da distribuição da altura de corte da segadora Case 8850 .... 55

12 Gráfico de controle para a média e amplitude do $\mathrm{n}^{\circ}$ de ciclos da prensa da enfardadora por fardo; (LSC: Limite Superior de Controle; LIC: Limite Inferior de Controle; LSE: Limite Superior de Especificação; LIE: Limite Inferior de Especificação)

13 Histograma da distribuição do número de ciclos da prensa da enfardadora por fardo

14 Gráfico de controle para a média e amplitude do comprimento dos fardos; (LSC:Limite Superior de Controle; LIC: Limite Inferior de Controle; LSE: Limite Superior de Especificação; LIE: Limite Inferior de Especificação) .... 59

15 Histograma da distribuição do comprimento dos fardos

16 Gráfico de correlação entre número de batidas da prensa da enfardadora e comprimento dos fardos 
17 Gráfico de controle para a média e amplitude do $n^{\circ}$ de ciclos da prensa da enfardadora por fardo, sem o controle eletrônico de contagem; (LSC: Limite Superior de Controle; LIC: Limite Inferior de Controle; LSE: Limite Superior de Especificação; LIE: Limite Inferior de Especificação)

18 Histograma da distribuição do número de ciclos da prensa da enfardadora por fardo, sem a utilização do sistema eletrônico de contagem

19 Gráfico de controle para a média e amplitude do $\mathrm{n}^{\circ}$ de ciclos da prensa da enfardadora por fardo, com o controle eletrônico de contagem; (LSC: Limite Superior de Controle; LIC: Limite Inferior de Controle; LSE: Limite Superior de Especificação; LIE: Limite Inferior de Especificação) 65

20 Histograma da distribuição do número de ciclos da prensa da enfardadora por fardo, com a utilização do sistema eletrônico de contagem 66

21 Gráfico de controle para a média e amplitude do comprimento dos fardos, sem o controle eletrônico de contagem; (LSC: Limite Superior de Controle; LIC: Limite Inferior de Controle; LSE: Limite Superior de Especificação; LIE: Limite Inferior de Especificação)

22 Histograma da distribuição do comprimento interno do fardo, sem a utilização do sistema eletrônico de contagem

23 Gráfico de controle para a média e amplitude do comprimento dos fardos, com o controle eletrônico de contagem; (LSC: Limite Superior de Controle; LIC: Limite Inferior de Controle; LSE: Limite Superior de Especificação; LIE: Limite Inferior de Especificação) 
24 Histograma da distribuição do comprimento interno do fardo, com a utilização do sistema eletrônico de contagem

25 Gráfico de correlação entre número de ciclos da prensa da enfardadora e comprimento interno dos fardos, para a operação executada sem o auxílio do sistema eletrônico de contagem

26 Gráfico de correlação entre número de ciclos da prensa da enfardadora e comprimento interno dos fardos para a operação executada com o auxílio do sistema eletrônico de contagem

27 Vista superior de um fardo com lados desuniformes

28 Gráfico da diferença média entre os comprimentos interno e externo dos fardos

29 Gráfico de correlação entre número de ciclos da prensa da enfardadora e a diferença média de comprimento entre os lados do fardo

30 Gráfico de posicionamento dos fardos no campo, com a introdução do GPS ao sistema eletrônico de contagem dos ciclos de prensagem

31 Gráfico de controle para a média e amplitude do $\mathrm{n}^{\circ}$ de ciclos da prensa da enfardadora por fardo, com GPS acoplado ao controle eletrônico de contagem; (LSC: Limite Superior de Controle; LIC: Limite Inferior de Controle; LSE: Limite Superior de Especificação; LIE: Limite Inferior de Especificação) 
32 Histograma da distribuição do número de ciclos da prensa da enfardadora por fardo, com a utilização do GPS acoplado ao sistema eletrônico de

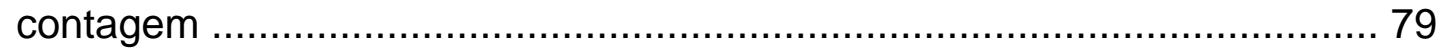

33 Mapa de produtividade para a cultura de feno ....................................... 80 


\section{LISTA DE TABELAS}

\section{Página}

1 Composição nutricional dos produtos segundo a classificação da proprie-

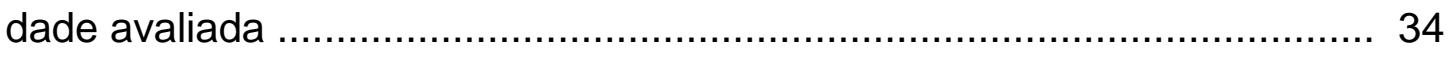

2 Desempenho operacional e econômico dos conjuntos mecanizados, para as sub-operações de fenação.............................................................. 48

3 Indicadores e limites de especificação utilizados para as operações de sega e enfardamento........................................................................... 50 


\title{
QUALIDADE OPERACIONAL DA FENAÇÃO: ANÁLISE DO PRODESSO DE PRODUÇÃO
}

\author{
Autor: RODRIGO GIACOMINI BONATO \\ Orientador: Prof. MARCOS MILAN
}

\section{RESUMO}

O Brasil possui atualmente o maior rebanho comercial bovino do mundo com aproximadamente 185 milhões de cabeças, configurando-se em uma atividade de significativa participação na formação do PIB agropecuário nacional. Entretanto, uma das dificuldades enfrentadas é a sazonalidade das forrageiras, pois a produção da pastagem concentra-se na época quente e chuvosa do ano. A fenação é uma das alternativas na conservação de forragens e sua qualidade depende, entre outros fatores, do processo de colheita, onde eficiência e agilidade são proporcionadas pela mecanização. $O$ momento econômico atual obriga os produtores rurais a adequarem seus sistemas produtivos, buscando novas tecnologias e soluções gerenciais que os fortaleçam na administração de suas propriedades. Deste modo, defeitos ou falhas em suas operações agrícolas devem ser detectadas e corrigidas, de modo a tornar os processos mais eficientes e, conseqüentemente, menos onerosos. Esta busca por menores custos e obtenção de melhorias ao sistema 
produtivo, pode ser alcançada pela implantação da gestão pela qualidade à administração empresarial. Os conceitos de qualidade foram desenvolvidos para o setor industrial e estão plenamente presentes à rotina das empresas e hoje, passaram a atuar também na agricultura, pois, uma vez que a cultura já tenha sido implantada, qualquer operação realizada fora dos padrões planejados traz inúmeras perdas. Devido ao alto custo do sistema produtivo agrícola, as operações mecanizadas representam um ponto estratégico para o desenvolvimento de técnicas de otimização e redução dos mesmos. Deste modo, este estudo teve por objetivo identificar e avaliar as operações de maior impacto nos custos e na qualidade para obtenção do feno enfardado. Os dados obtidos em uma propriedade produtora de feno, foram analisados utilizando-se - Controle Estatístico de Processos (CEP) e as operações de sega e enfardamento foram consideradas críticas sob o ponto de vista econômico e qualitativo em relação ao produto final (feno). Para a operação de sega, os resultados indicaram que existem causas especiais atuando no processo, bem como tendência de execução da operação acima dos limites estabelecidos, devido ao receio de contaminação da massa ceifada. Na operação de enfardamento constatou-se um maior potencial de melhoria e para tanto, exigiu que um dispositivo eletrônico de contagem fosse acoplado ao equipamento, melhorando a qualidade do processo produtivo, principalmente com relação à conformação dos fardos: manutenção do comprimento e geometria. Enfim, a implantação de sistemas de controle de qualidade em operações agrícolas mecanizadas para a cultura de feno é viável e, com o CEP, foi possível caracterizar tecnicamente a qualidade de execução das operações e gerar melhorias na qualidade final do produto.

PALAVRAS CHAVES: CEP; Fenação; Mecanização agrícola; Qualidade Total. 


\title{
OPERATIONAL QUALITY OF HAY HARVESTING: ANALYSIS OF THE PROCESS
}

\author{
Author: RODRIGO GIACOMINI BONATO \\ Adviser: Prof. MARCOS MILAN
}

\section{SUMMARY}

In the very beginning of the 21st century Brazil has nearly 185 million cattle, the biggest livestock of the world, which agribusiness contributes significantly to the GNP of the country. Most of those animals feed in pasture land and one of the main constraints is the seasonality of the herbage, that is, in the winter time the drought restrict the availability of food. Hay is one of the alternatives to counteract that problem and its quality depends on the process of harvesting, among others, in which the agility and efficiency is given by the mechanization. Nowadays rural activity requires cost-effective administration like any other enterprise, so that the producers have to constantly pursue new technologies and managerial processes. Faults and defects in the operations must be detected in time and properly corrected in order to get efficiency in the process, that is, a minor cost. This search for a lower cost can be reached applying the quality management in the business administration. The concepts of quality were developed to the industrial sector and, fully incorporated to the 
routine administration of the enterprises of that sector, now come to be applied to the agribusiness alike. Due to the high cost of the agricultural production process, a strategic move is the development of techniques to optimize and reduce the mechanized operations. This study aimed at the identification and evaluation of the operations which most impact the cost and quality of the hay harvesting and packing. Data obtained in a hay production farm were analyzed by means of the Statistical Quality Control (SQC) and both the tillage and packing were considered the key points under the economical and quality view in relation to the final product, the fodder. Concerning the tillage, the results indicated the existence of special causes acting in the process, as well as a tendency to operate the machines above the required limits due to the fear of adulterations in the reaped mass. As it was detected that in the packing process prevail the biggest potential to improve, an electronic device of counting was set up in the equipment. This recourse improved somewhat the productive process, mainly in relation to the format of the package: proper maintenance of the length and geometry. In conclusion, the introduction of quality control systems in the mechanized processes of hay harvesting is feasible and, the SQC make it possible to technically characterize the quality of the operations, which leads to a better fodder.

KEYWORDS: SQC; hay; mechanization; total quality. 


\section{INTRODUÇÃO}

A globalização da economia acirra a competitividade empresarial, de forma que o lucro passa a ser obtido pela otimização e minimização dos custos. No setor agrícola tais aspectos não são diferentes e ainda, em contraponto à indústria, são agravados pelo fato de seus produtos possuírem preços fixados pelo mercado vigente, influenciados pela economia de outros centros produtores e pelos estoques mundiais, o que requer profissionalismo dos produtores e os obrigam a buscar novas técnicas e aspectos gerenciais administrativos que os fortaleçam e satisfaçam as necessidades do mercado.

No ano de 2003, o Produto Interno Bruto (PIB) do agronegócio brasileiro (produção primária, insumos, distribuição e agroindústria) apresentou um crescimento de $8,13 \%$, encerrando o ano com a geração de cerca de 458 bilhões de reais. Por sua vez, o PIB referente ao agronegócio da pecuária registrou crescimento de 4,52\%, acumulando 55 bilhões de reais e $2,86 \%$ de aumento da produção até o terceiro trimestre, com incremento de 1,62\% dos preços médios reais praticados (Confederação da Agricultura e Pecuária do Brasil - CNA, 2003; Centro de Estudos Avançados em Economia Aplicada CEPEA/USP, 2003)

O Brasil destaca-se como o principal agente mundial do setor pecuário, possuindo o maior rebanho bovino comercial do mundo, estimado em 185 milhões de cabeças e exportações de mais de 1,3 milhões de toneladas de carne bovina no ano de 2003 (Instituto Brasileiro de Geografia e Estatística IBGE, 2003; Confederação da Agricultura e Pecuária do Brasil - CNA, 2003). 
Para as empresas pecuárias brasileiras atenderem ao incremento de demanda e manterem a participação no mercado mundial, há necessidade de se melhorar a produtividade tanto do rebanho, quanto da cultura forrageira e, para ampliar o ganho com a atividade, devem otimizar seus custos.

A exploração animal baseada no uso intensivo de pastagens torna a atividade mais econômica, pois quem realiza a colheita é o próprio animal. Entretanto, a distribuição da produção de forragem é irregular e concentra-se na época quente e chuvosa do ano. Portanto, a sazonalidade dificulta a economia da atividade e impede que o potencial de produção das plantas forrageiras seja aproveitado ao longo de todo o ano, o que suscita em uma crescente busca por processos de conservação de forragens, a fim de se garantir o fornecimento constante de alimento aos animais.

Deste modo, o processo de fenação surge como uma das possíveis soluções ao problema da estacionalidade das plantas forrageiras, permitindo que o excedente produzido em pastagens ou em áreas exclusivas de cultivo, possa ser armazenado e empregado na alimentação dos animais em épocas de escassez, constituindo-se em uma importante fonte constante de alimento, além de se caracterizar como uma nova oportunidade agrícola, a qual já desperta interesse de vários produtores.

A fenação tem por objetivo propiciar a perda rápida de água na planta forrageira, conservando ao máximo seu valor nutritivo, de modo que há um consenso entre os autores: "na fenação, a pressa é amiga da perfeição", pois quanto mais rápido for o processo de desidratação, mais rapidamente se detém a respiração e obtém-se um produto final de melhor qualidade.

No Brasil, o sistema de produção de feno a campo é o mais empregado e difundido, utilizando energia solar para o processo de desidratação do material vegetal, o que exige menores investimentos em instalações e equipamentos. Porém torna-o extremamente dependente dos fatores climáticos, uma vez que o processo de secagem no campo envolve perda e absorção de água e restringe as horas de aptidão ao trabalho. 
Em decorrência do pouco tempo apto para a execução do processo de fenação, faz-se necessário o emprego de alta tecnologia, exigindo que as operações sejam mecanizadas e muito bem gerenciadas, para que não representem apenas em acréscimo no custo de produção, mas que realmente impliquem em eficiência e agilidade. As operações mecanizadas de qualquer sistema de produção são um ponto estratégico para o desenvolvimento de técnicas de otimização e redução dos custos, pois segundo pesquisas realizadas pelo Instituto de Economia Agrícola (IEA) no estado de São Paulo, os custos com maquinarias agrícolas para as principais culturas anuais representam entre $21,7 \%$ e $40,5 \%$ do custo total de produção.

Desta forma, a implantação de um programa eficiente para controle de custos na agropecuária pode ser estruturado nos conceitos de gestão pela qualidade total, onde a aplicação de ferramentas do Controle Estatístico de Processos (CEP), largamente utilizadas no setor industrial, podem contribuir para a redução de custos, identificação de problemas na rotina de trabalho e manutenção de padrões desejados nas operações. A viabilização do controle de operações através do uso de ferramentas estatísticas da qualidade, permite a localização das variações ou oscilações nas operações agrícolas por meio de amostragens e análises em tempo real, minimizando a possibilidade de concretização das mesmas fora dos padrões de qualidade especificados.

Considerando a importância da fenação como fonte suplementar na alimentação animal e da mecanização no modelo de produção, aliada à necessidade de manutenção dos padrões de qualidade na obtenção do produto final, o presente trabalho teve por objetivo identificar e avaliar as operações de maior impacto nos custos e na qualidade para obtenção do feno enfardado. 


\section{REVISÃO DE LITERATURA}

\subsection{Fenação}

\subsubsection{Descrição e importância}

Segundo Haddad \& Castro (1998), a fenação é um processo de conservação de forragens já dominado pelo homem há muito tempo. Existem registros de que expedições britânicas e francesas encontraram nos túmulos dos antigos faraós alimentos parcialmente conservados, dentre eles o feno, provando assim, que seu uso é conhecido há muitos séculos. No Brasil, o processo de fenação foi motivado pela eqüinocultura, que em seus primórdios adotou o sistema clássico de criação, baseado nas tecnologias anglo-francesas, onde os animais recebem o alimento nas baias. No início da década de noventa a crise econômica se instalou na criação de cavalos e diversos haras eliminaram seu plantel, direcionando sua atividade no sentido de produção e comercialização do feno.

O fato de se formarem campos exclusivos de produção de feno não trouxe como conseqüência a elaboração de um produto de excelente qualidade. Apenas com a introdução de tecnologias mais avançadas e a adoção da irrigação, obteve-se um produto de alta qualidade durante todo 0 ano, minimizando-se a interferência da estacionalidade (Haddad, 1992; Alvim et al., 1996).

A essência do processo de fenação é provocar a rápida perda de água pela planta forrageira, para que esta conserve ao máximo suas características 
nutricionais. Sendo assim, a partir do momento que a técnica de produção de feno passa a ter caráter comercial e ser empregada em larga escala, o clima torna-se uma variável fundamental do sistema, pois fatores como temperatura, umidade do ar, velocidade do vento e principalmente radiação solar, influem diretamente na velocidade de secagem da massa vegetal e conseqüentemente alteram a qualidade do produto final (MacDonald \& Clarck, 1989; Haddad \& Castro,1998).

Calcerley (1970), descreve que a fenação já foi aplicada com grande êxito na Inglaterra, sendo que na década de setenta, 90\% da forragem era conservada sob este processo. Porém, devido à alta umidade, esse país não apresenta um clima favorável à fenação. Cherry (1970), explica que o processo de fenação só era possível neste país devido à utilização intensa dos pequenos intervalos de tempo seco.

Faria (1975) e Faria \& Corsi (1993), descrevem o fato de que no Brasil Central o processo de fenação seria difícil de ser posto em prática, visto que a estação das chuvas seria coincidente com a época de crescimento das forrageiras. A transferência da produção para o período mais seco do ano, entre março e abril, acarretaria em perdas nutricionais do produto final em decorrência do menor valor nutritivo da planta neste período.

Desta forma, Faria \& Corsi (1993), recomendam que para as áreas sem irrigação, o corte e desidratação das plantas forrageiras no Brasil Central, ocorram no período das águas, entre os meses de outubro e março, aproveitando-se intensamente os curtos intervalos de tempo seco, uma vez que levantamentos meteorológicos de localidades dispostas nesta região brasileira indicaram existir a possibilidade de $50 \%$ do tempo sem chuvas. A justificativa dos autores para a realização da fenação nesta época do ano é o melhor aproveitamento das características climáticas disponíveis para o crescimento das plantas.

Para os meses de seca, de abril a setembro, Haddad \& Castro (1998), apontam a utilização de irrigação para a continuidade do sistema de produção. 


\subsubsection{O processo de fenação}

Técnicas de fenação foram descritas por Faria (1975) e Lavezzo \& Andrade (1994), nas quais a primeira etapa a ser realizada no processo de fenação é a sega, executada por máquinas especiais denominadas segadoras ou ceifadoras. Os autores ressaltam a importância do momento de corte da forrageira, pois a qualidade do feno obtido está extremamente relacionada com o estádio vegetativo da forragem e seu nível de adubação. Outro fator a ser considerado é o período do dia a se realizar a sega, de modo a evitar que a forragem seja ceifada com orvalho, o que provocaria acúmulo de água na massa depositada no solo, requerendo portanto vários revolvimentos, para secagem adequada. O revolvimento é a fase mais importante da fenação, pois se bem realizada, acelera a desidratação e alcança o ponto de feno desejado, ou seja, umidade da massa vegetal entre 12 e $18 \%$. A movimentação da massa é efetuada com ancinhos revolvedores, os quais são capazes de revirar eficientemente o material, permitindo trocas gasosas e perda da umidade para o ambiente. Após esta fase, é realizado o enleiramento, executado por ancinhos enleiradores, onde a forragem é concentrada em faixas longitudinais. A operação seguinte é o enfardamento, realizado com auxílio da enfardadora, a qual recolhe e prensa a forragem enleirada, formando os fardos de feno, que podem ser cúbicos ou cilíndricos. Finalmente tem-se o recolhimento, operação realizada com máquinas recolhedoras, as quais organizam os fardos espalhados no campo, gerando pilhas que, na próxima operação serão colocadas em carretas de transportes e levadas para armazenamento em galpões fechados.

O mercado dispõe de uma gama variada de máquinas exclusivas para a fenação, na sua maioria importadas que, conseqüentemente despendem altos investimentos de aquisição e manutenção. Certamente a compra destas máquinas por propriedades produtoras, visa melhorar a eficiência de seu curto espaço de trabalho, exigindo gerenciamento eficiente do sistema mecanizado, 
uma vez que boa parte dos custos de produção serão decorrentes das atividades mecânicas, essencialmente do sistema mecanizado de colheita, onde emprega-se elevado número de máquinas e pode ser considerado ponto crucial à qualidade do produto final (Pizarro et al., 1980; Seiffert, 1980).

Deve-se considerar também, que a área a ser fenada deve ser mantida livre de restos de madeiras, pedras, cupins, valetas e quaisquer outros obstáculos, além de possuir boa topografia e sistematização de talhões e estradas, a fim de facilitar a operação de mecanização e conseqüentemente garantir a eficiência do sistema (Haddad \& Castro, 1998).

\subsubsection{Qualidade do produto}

A qualidade do feno está diretamente ligada à maturidade das plantas, tendo-se que a época adequada para o corte é aquela em que a planta forrageira apresenta crescimento vigoroso e bom valor nutritivo (Faria \& Corsi, 1993), buscando-se aliar bom rendimento por unidade de área com adequado índice nutricional.

A produção de matéria seca por unidade de área eleva-se com o aumento da maturidade das plantas forrageiras, mas à medida que se prolonga o tempo de crescimento, ocorrem alterações que resultam na elevação dos teores de compostos estruturais, como celulose, hemicelulose, lignina e, paralelamente, diminuição do conteúdo celular, o que certamente ocasionará redução dos nutrientes potencialmente digestíveis, Minson (1990).

Faria (1975) e Pereira \& Reis (1999), afirmam que com o desenvolvimento da planta forrageira, observa-se à diminuição de seu valor nutritivo, bem como a redução de sua relação folha/caule e conteúdo de água. Sob o aspecto da desidratação, deve-se salientar que plantas mais novas possuem teores mais elevados de água, porém sua proporção de folhas é maior, o que facilita sua secagem. De acordo com os mesmos autores, as folhas das gramíneas perdem 
água quinze vezes mais rápido que os caules, sendo que $25 \%$ da água dos caules é perdida por intermédio das folhas.

A fenação é, portanto, um processo de conservação, no qual há a desidratação enérgica e parcial da massa, retirando-se a água disponível à ação deletéria de microrganismos, fazendo com que o produto final (feno) se conserve por muito tempo (Haddad \& Castro, 1998). Raymond et al (1978), consideram que a desidratação atinge o "ponto de cura" quando a umidade da massa atinge 15 a $18 \%$, o que corresponde a uma umidade relativa do ar entre 60 e $70 \%$. Faria \& Corsi (1993), atribuem ao ponto de cura, umidades entre 12 a $16 \%$, com umidade relativa do ar ao redor de 60 a $70 \%$, sendo que a secagem da massa ceifada continua se processando enquanto a umidade relativa do ar for menor que o ponto de equilíbrio para o feno e que umidades relativas acima de $70 \%$ impedem a completa desidratação da planta.

A qualidade química do feno relaciona-se com sua capacidade de fornecer aos animais os nutrientes orgânicos e minerais por eles exigidos, expressando o valor nutritivo da forragem, avaliado quimicamente pelo teor de proteína, fósforo, cálcio e digestibilidade de matéria seca (Gomide, 1980). Ao longo do desenvolvimento do processo de fenação, várias plantas forrageiras já foram utilizadas e, segundo Silva et al. (1998), atualmente o gênero Cynodon se adequa perfeitamente ao processo de fenação, possuindo facilidade de cultivo e alta produção (20 a 25 t de matéria seca/ha ano), além de um bom valor nutritivo (11 a $13 \%$ de proteína bruta e 58 a $65 \%$ de digestibilidade). Espécies como Coastcross, Florakirk, Tifton-68 e Tifton-85 apresentam talos bastante finos, reduzindo o diferencial de desidratação entre folhas e caules e, portanto, produzindo um feno de qualidade em um curto tempo de secagem. Estas espécies também sofrem menos influência do fotoperíodo, o qual afeta negativamente a produção.

A ocorrência de chuvas durante o processo de secagem também afeta a qualidade do feno, podendo gerar perdas em torno de $30 \%$ da matéria seca, a qual tem sua maior parte perdida sob compostos altamente digestíveis (Rotz \& 
Muck, 1994). A intensidade da perda depende da intensidade e duração das chuvas e, geralmente, o efeito é mais desfavorável nos estádios finais do processo de secagem da massa ceifada (Faria \& Corsi, 1993).

Outros fatores que influem na produção e qualidade química do feno são a fertilidade do solo, principalmente com os níveis de nitrogênio e potássio, pragas e doenças, e com o armazenamento dos fardos, no qual é de suma importância vistorias diárias para detecção de fermentação indesejável (Haddad \& Castro, 1998).

Visto os fatores de influência na qualidade química do feno, Faria \& Corsi (1993), descrevem, sob o ponto de vista físico, a classificação do feno que o mercado brasileiro adota, denominando-se de tipo A aquele produzido com forrageiras novas e de alto valor nutritivo, proporcionando um material com coloração verde e isento quaisquer tipos de contaminação, como fungos e materiais estranhos. O feno do tipo B é produzido com forragem mais matura, obtendo-se maior rendimento por área em detrimento ao valor nutritivo, resultando em um produto final mais amarelado. Já o tipo $C$ provém de forragem passada ou de fenos A ou B que sofreram chuvas, onde o valor nutritivo fica comprometido e conseqüentemente é destinada a animais de baixa exigência nutricional, ou a moinhos fornecedores de forragem moída a fábricas de rações.

Obviamente o preço é função da qualidade química e física do feno, de modo que a produção é voltada à obtenção do melhor produto final possível, o qual somente é obtido pelo consorciamento de uma forrageira de alto rendimento e valor nutritivo a um sistema de produção tecnificado e muito bem gerenciado, o qual deve ser capaz de dominar as imposições climáticas, aproveitando-se intensamente os pequenos intervalos de tempo seco fazendose uso da maquinaria disponível na propriedade (Seiffert, 1980; Siewerdt, 1980). 


\subsection{Sistemas mecanizados}

\subsubsection{Desempenho operacional e econômico de sistemas mecanizados}

De acordo com Mialhe (1974), o desempenho operacional de um sistema mecanizado pode ser definido como um complexo conjunto de informações que determinam, em termos quali-quantitativos, os atributos para a execução das operações sob determinadas condições de trabalho. As informações podem ser pertinentes às características operacionais (qualidade e quantidade do trabalho), dinâmicas (potência requerida e velocidade de trabalho) e de manejo (regulagens, reparos e manutenções).

Desta forma, Mialhe (1996), define desempenho teórico como aquele que o projetista do equipamento tomou como base para o dimensionamento e execução dos cálculos estruturais e como desempenho operacional, os parâmetros que representam uma medida do comportamento da máquina sob condições reais de operação, refletindo a interação entre as constantes construtivas, as variáveis operacionais e as condições de manejo do conjunto mecanizado.

A capacidade de campo de um sistema mecanizado pode ser caracterizada como efetiva, sendo a razão entre o desempenho atual em um tempo dado e o tempo total de campo; teórica, como a razão de desempenho obtida, se a máquina trabalhar $100 \%$ do tempo à velocidade nominal, utilizando 100\% de sua largura nominal (Balastreire, 2000); operacional, a qual representa a capacidade da máquina ou implemento no campo, incluindo os efeitos de fatores de ordem operacional, como tempos consumidos no preparo da máquina e em interrupções requeridos pelo próprio trabalho da máquina quando em operação no campo (Mialhe, 1974).

Enfim, Mialhe (1996) define capacidade como o conjunto de características relacionadas com a intensidade operacional ou taxa de realização de trabalho e 
eficiência como as características relacionadas com perdas ou desperdício de tempo, combustível e potencial operacional.

Sob esse enfoque, Banchi et al. (1994) em estudos para o setor canavieiro ressalta que a utilização de máquinas agrícolas é essencial para o aumento de áreas cultivadas e agilização da execução dos serviços. Porém seus custos são expressivos e justificam acompanhamento técnico e gerencial rigoroso. Os autores relatam também, que a frota canavieira de máquinas agrícolas convive com eficiências de uso muito baixas, girando em torno de $25 \%$.

Portanto, a gerência de uma propriedade agrícola deve direcionar seus esforços na garantia da qualidade de seus produtos e na obtenção das metas de produção, sendo capaz de construir um sistema agrícola pela associação das características do ambiente físico, com as tecnologias adequadas e economicamente disponíveis (Mialhe, 1974).

Brugnaro \& Sbragia (1984), consideram o ambiente como um conjunto de fatores fixos, como clima, solo e planta, sendo a interação destes, pouco flexíveis a mudanças. Assim a tecnologia a ser escolhida para o sistema deve ser adequada para que se possa conferir agilidade ao manejo da propriedade agrícola.

Mialhe (1974), afirma que para que se detenha o controle dos meios de produção, que consiste na ação de aferir e comparar realizações e previsões, torna-se de fundamental importância o planejamento das atividades agrícolas, que segundo Brugnaro \& Sbragia (1984), consiste em um processo que baseando-se em um conjunto de informações, obtém-se como produto final procedimentos e critérios para a construção das estratégias de produção e uso do sistema mecanizado.

Veiga (2000), ressaltou que na cultura da soja os custos diretos referentes ao uso de máquinas agrícolas podem chegar a $40 \%$ dos custos de produção no plantio convencional e $30 \%$ no plantio direto.

Barbosa et al. (1998), afirmam que a maquinaria agrícola possui papel fundamental no processo produtivo, participando de uma série de operações 
que vão desde as práticas iniciais de cultivo à colheita, podendo representar até $40 \%$ do custo total de produção.

Lopes \& Milan (1998), trabalhando com modelagem em sistemas mecanizados sucro-alcooleiros, observam que a colheita é um fator importante na construção dos custos, podendo representar entre 30 e $40 \%$ dos custos de produção totais de cana-de-açúcar.

Desta forma, as decisões de planejamento, seleção e gerenciamento do sistema mecanizado de uma propriedade são fatores vitais à lucratividade do sistema produtivo, sendo necessária a determinação cuidadosa dos custos fixos, operacionais e de oportunidade (Ozkan \& Holmes, 1990).

\subsubsection{Determinação dos custos diretos e operacionais}

O desempenho econômico das máquinas agrícolas é estimado pelos custos operacionais, os quais dividem-se em custos fixos e variáveis (Witney, 1988). Os custos fixos são aqueles que incidem independentemente do uso da máquina, tais como depreciação, juros, seguro e alojamento. Já os custos variáveis são aqueles dependentes do uso, como combustíveis, lubrificantes, reparos e manutenção e mão de obra (Hunt 1973; Milan \& Crossley, 1998).

Existem inúmeros trabalhos que definem os tipos de custos pertinentes à sistemas mecanizados e a forma de estimá-los, porém os profissionais da área de mecanização vêm se orientando pela metodologia sugerida pela ASAE, a qual associou as informações obtidas em diversos trabalhos executados sob diferentes situações e com máquinas semelhantes, obtendo equações padronizadas (Molin \& Milan, 2000). 


\subsubsection{Avaliação de sistemas de produção de feno}

Thylén \& Sundberg (1994), realizaram estudos na Suécia entre os anos de 1988 e 1993, onde associaram dados meteorológicos destes seis anos com a colheita de feno, criando um modelo para auxiliar nas tomadas de decisões dos fazendeiros daquele país. Diariamente, fatores climáticos como precipitação, radiação solar, temperatura e umidade relativa do ar, juntamente com dados de rendimento operacional da maquinaria disponível, alimentavam um programa computacional que analisava as condições e indicava como deveriam ser as operações em áreas já ceifadas, ou se poderia ser realizado o corte de novas áreas, mostrando inclusive o tamanho ideal da gleba a ser fenada em função do tempo apto disponível e da capacidade operacional dos equipamentos. Os resultados indicaram que a maioria das previsões de chuvas foi confirmada para a região do experimento, de forma que os dias disponíveis para a realização do corte limitaram-se consideravelmente. Os autores concluíram que a qualidade de processo de fenação possui íntima correlação com os fatores climáticos, os quais limitam o tempo de trabalho no campo e exigem alternativas gerenciais mais eficientes ao sistema.

Ribeiro et al. (1999), avaliaram o desempenho operacional e econômico de máquinas para fenação em cultura de coast-cross, utilizando-se equipamentos de baixa tecnologia. Observaram que as operações de corte e enfardamento demandaram maior tempo e quantidade de energia, tendo-se como fatores analisados a velocidade de deslocamento das máquinas, quantidade e altura da massa verde a ser cortada, além da largura e altura das leiras a serem recolhidas pelas enfardadoras. Verificou-se também que em áreas planas e de grande extensão, o número de manobras é reduzido e proporciona melhor eficiência ao sistema de colheita. Os autores ressaltam a introdução de maquinaria de alta tecnologia no mercado brasileiro e afirmam a necessidade de se obter maiores dados sobre as operações mecanizadas de fenação. 


\subsection{Controle da qualidade em processos produtivos}

Atualmente a administração de qualquer sistema de produção tornou-se tão importante quanto o próprio trabalho a ser executado, conforme este vai se especializando e a escala de operações se amplia. A administração não é um fim em si mesma, mas um meio de fazer com que os processos sejam realizados da melhor forma possível, com o menor custo e com maior eficiência e eficácia (Chiavenato, 1983).

Desta forma, como abordagem administrativa nas empresas, o Controle da Qualidade Total (CQT) objetiva justamente a criação de condições internas que garantam a execução dos processos adequadamente, com custos e eficiência otimizados, assegurando a sobrevivência das organizações a longo prazo (Campos, 1992).

Dodson (1998) enfatiza que o conceito de qualidade não deve restringir-se apenas na etapa final de produção, pois cada produto defeituoso representa desperdício de material, tempo e energia, além de comprometer a imagem do produto e fabricante. Logo, a qualidade deve ser incorporada aos processos produtivos e administrativos, buscando a qualidade da empresa como um todo e não somente do produto final.

\subsubsection{Histórico da qualidade}

A idéia de qualidade vem de longa data, na Idade Média (séc. XII - XIII) a produção de mercadorias era realizada por artesões, sob rígidas normas de produção e individualização de clientes. Porém, no séc. XVIII, com a Revolução Industrial, os bens passaram a ser produzidos em larga escala, originando bens baratos e populares (Cunha \& Bartholo, 1986).

Assim, os problemas de qualidade foram se somando à medida que o setor industrial expandia suas fronteiras, até que, a partir da década de 1920, 
com o final da Primeira Guerra Mundial, os conceitos de qualidade começaram a ser aplicados novamente, a fim de se impedir que produtos defeituosos chegassem às mãos dos clientes (Antunes \& Engel, 1999). Este foi o primeiro passo na busca da qualidade, porém a inspeção, na produção de massa, gerava elevado ônus e não evitava desperdícios, uma vez que o custo de produção de um produto defeituoso é o mesmo que de um produto isento de problemas (Miranda, 1994).

O segundo passo na estruturação da filosofia da qualidade foi dado após o final da Segunda Guerra Mundial, quando o conceito abrangente de gestão pela qualidade foi desenvolvido no Japão e passou a ser encarado como uma esperança à situação de crise enfrentada pelo país, especialmente devido à sua capacidade de redução de custos de produção. O desenvolvimento deste conceito teve referência teórica e acompanhamento de cientistas norteamericanos, podendo-se citar essencialmente dois nomes, Deming e Juran, para os quais, qualidade fundamenta-se na eliminação de erros sistemáticos na produção e ausência de deficiências no produto (Sariés, 1997).

$\mathrm{Na}$ década de 1960, o mercado mundial sofreu mudanças significativas com o emprego de altas tecnologias de produção, redução das barreiras internacionais e acirramento da competitividade internacional, fatores que alteraram o comportamento dos consumidores, os quais passaram a exigir produtos de melhor qualidade a preços mais acessíveis (Antunes \& Engel, 1999).

Finalmente, nos dias atuais, os conceitos de qualidade estão plenamente presentes à rotina das grandes empresas e passam a atuar também nas médias e pequenas empresas, tornando-se parte fundamental da administração moderna, participando inclusive, nas tomadas de decisões das próprias pessoas, como "entidades" independentes (Schierz, 1999). 


\subsubsection{Definição de qualidade}

O termo qualidade vem sendo analisado sob várias abordagens distintas, originando inúmeros conceitos e definições.

Assim, para Juran (1990), Rothery (1993) e Montgomery (1996) qualidade é a adequação ao uso, ou seja, um produto deve atender às exigências dos consumidores, cumprindo adequadamente suas funções.

Para Gitlow (1993), qualidade é um julgamento feito pelos clientes ou usuários de um produto ou serviço, com relação à superação de suas expectativas.

Reeves \& Bednar (1994) trazem diversas definições para qualidade, como excelência (qualidade significa o melhor que se pode fazer, o padrão mais elevado de desempenho); valor (qualidade significa ter mais atributos, usar materiais ou serviços raros, que custam mais caro); especificações (qualidade planejada, definição de como o produto ou serviço deve ser); conformidade (qualidade significa o produto ou serviço estar de acordo com as especificações do projeto); regularidade (qualidade significa uniformidade, de forma que produtos e serviços sejam os mais parecidos possíveis); adequação ao uso (qualidade significa adequado projeto e ausência de deficiências).

Campos (1992) divide o conceito de qualidade total em cinco dimensões, a qualidade intrínseca, o custo, a entrega, o moral e a segurança. A qualidade intrínseca está diretamente ligada à satisfação das necessidades dos clientes; o custo refere-se ao aporte de capital para produção do bem; a entrega significa pontualidade nos prazos estipulados; o moral é o alicerce da qualidade e reflete o ambiente de trabalho e comprometimento da equipe; e segurança engloba tanto aspectos de segurança do processo, quanto de uso seguro do produto pelos consumidores. $O$ autor considera estas cinco dimensões da qualidade total como "pilares" que sustentam a sobrevivência da empresa no mercado.

A Norma ISO (International Organization for Standatization) número 8402 (2002), define qualidade como a totalidade das características de uma entidade 
(empresa de prestação de serviços) que the confere a capacidade de satisfazer necessidades explícitas (especificadas no contrato) e implícitas (não especificadas no contrato, mas que a empresa deve satisfazer, para obter um diferencial competitivo) dos clientes.

Vieira (1999) afirma que a qualidade deve ser vista sob dois aspectos, a de projeto, que diferencia os bens de luxo dos bens populares e a de conformação, na qual verificam-se os produtos de acordo com as especificações de projeto. Portanto, para a autora, dois produtos jamais serão idênticos em função da variabilidade de produção e, assim, qualidade é definida como a redução da variabilidade, a qual pode ser obtida pelo Controle Estatístico do Processo (CEP).

\subsubsection{O controle estatístico de processos (CEP)}

O gerenciamento pela qualidade total exige mudança de postura e, até mesmo de rompimento, dos gerentes e dos trabalhadores de uma empresa $A$ hierarquia gerencial deve ocupar-se com o desenvolvimento da tecnologia de trabalho dos empregados e estes se tornarem responsáveis pela manutenção da rotina de trabalho (Bonilla, 1995), a qual pode ser controlada através do CEP.

Trindade et al. (2000) definem o CEP como uma ferramenta para manutenção das variáveis dentro dos limites ou padrões estabelecidos por normas técnicas, a fim de que o processo se comporte de forma controlada. Por este processo, as conclusões e tomadas de decisões sempre estão embasadas em dados numéricos (estatísticos), constituídos pela combinação entre mão de obra, materiais, máquinas, métodos, meio ambiente e medições.

Para Campos (1992), os resultados obtidos com as melhorias devem ser mantidos através de um bom gerenciamento, no qual o método mais adequado seria o emprego do controle estatístico de processos (CEP). 
Vieira (1997) concorda com a eficiência do emprego do CEP no gerenciamento empresarial, citando Ishikawa, para o qual, o uso das ferramentas estatísticas da qualidade pode resolver aproximadamente $95 \%$ dos problemas de qualidade em qualquer tipo de organização, seja industrial, comercial, de pesquisa ou prestação de serviços. Segundo a mesma autora, as Sete Ferramentas para o Controle da Qualidade devem estar associadas, na cultura japonesa, às sete armas samurais, fazendo uma alusão implícita à sobrevivência empresarial.

Segundo Vicino (2000), as Sete Ferramentas para o Controle da Qualidade, criadas por Ishikawa são: Folha de verificação, Estratificação, Diagrama de dispersão Gráfico de controle, Diagrama de Pareto, Histograma e Diagrama de causa e efeito.

O uso do CEP na indústria visando eficiência e produtividade, foi iniciado a partir do trabalho de W.E.Deming, estatístico norte americano que atuou junto às forças armadas dos E.U.A. durante a Segunda Guerra Mundial e que, no pós-guerra foi levado ao Japão pelo general MacArthur para auxiliar na reconstrução do parque industrial japonês. A estratégia de Deming foi a utilização da estatística para a tomada de decisões administrativas. Em 1950, Deming levou para o Japão J.M. Juran, criador do gráfico de Pareto, onde cerca de $80 \%$ dos problemas deve-se a $20 \%$ das causas. A importância destes dois cientistas americanos para a evolução da filosofia da qualidade no Japão e no mundo, é comprovada pelos dois mais importantes prêmios da qualidade levarem seus nomes (Vicino, 2000).

Assim, Fernandes (2000) e Trindade (2000), citam que as vantagens da introdução do CEP na administração empresarial são o surgimento do conhecimento significativo e a compreensão dos processos, obtendo maior estabilidade e previsibilidade do processo, a dependência da inspeção em massa pode ser eliminada ou reduzida com a maior delegação do gerenciamento do processo aos operadores, os custos da não-qualidade (retrabalhos, refugos e insatisfação do cliente) podem ser minimizados, as 
programações de operações são cumpridas com conseqüente ganho de produtividade e finalmente, o diálogo e comunicação dentro da empresa tornam-se mais claros e eficientes.

\subsubsection{Conceitos do controle estatístico de processos (CEP)}

- Indicadores da qualidade

Segundo Pasqua (1999), para avaliar um processo ou operação, é necessário definir alguns indicadores dentro do processo, a fim de se permitir a inferência do resultado final como adequado ou fora da qualidade desejada. Desta forma, as aspirações em relação à operação devem ser traduzidas em indicadores mensuráveis ou passíveis de avaliação, utilizando-se linguagem técnica e objetiva.

\section{- Padrões da qualidade}

$\mathrm{Na}$ filosofia da qualidade existem dois tipos de gerenciamento, o da rotina e o das melhorias. No primeiro, o gerenciamento é baseado no planejamento, execução, checagem e correção de falhas, ou seja, é de responsabilidade dos funcionários e deve garantir o bom andamento da rotina de trabalho. Já no segundo tipo de gerenciamento, a diretoria da empresa é responsável pela melhoria das operações, objetivando adequação de máquinas e equipamentos, bem estar dos funcionários, maior competitividade de seus produtos e redução de custos (Andriani, 1996).

Assim, para cada indicador de qualidade, devem ser definidos os padrões de qualidade ou as especificações que cada um deles deve respeitar, de modo que o gerenciamento da rotina possa ser realizado adequadamente pelos funcionários. 
Portanto, na implantação dos padrões de qualidade deve-se, primeiramente, conhecer a realidade de execução das operações, a fim de se definir valores máximos e mínimos (amplitude) permitidos a cada operação. Obtendo-se sucesso na primeira etapa, ou seja, alcançando-se a regularidade da rotina de trabalho, a diretoria deve assumir o gerenciamento das melhorias e estipular novos limites ou padrões, adotando um processo de melhoria contínua dentro da empresa. Este processo de melhoria contínua é denominado Kaizen (Bonilla, 1995).

- Gráfico de controle ou Cartas de controle

Segundo Trindade et al., o gráfico de controle foi originalmente proposto por Shewhart em 1924, para o acompanhamento de seu trabalho na Bell Telephone Laboratories na diferenciação de variações anormais (nãoaleatórias) das variações normais de um processo (aleatórias).

As cartas de controle são muito utilizadas por refletirem a variabilidade existente em um sistema, sendo representadas por gráficos de acompanhamento, determinados estatisticamente e compostos por uma linha superior chamada de limite superior de controle (LSC), uma linha central que representa a média obtida das medições dos atributos analisados e uma linha inferior, denominada limite inferior de controle (LIC). Preferencialmente deve-se utilizar um grupo de dados na composição de cada amostra, a fim de se ter menor variação do que em amostras individuais, agregando maior confiabilidade à análise (Pasqua, 1999; Fernandes, 2000).

Vieira (1999) traz as fórmulas para o cálculo dos limites de controle para as cartas de média e de amplitude:

$$
\begin{array}{lc}
L S C_{X}=x+A_{2} R & \text { Onde: } x=\text { média das médias dos subgrupos; } \\
L I C_{X}=x-A_{2} R & \mathrm{R}=\text { média das amplitudes de cada } \\
L S C_{R}=D_{4} R & \text { subgrupo; } \\
L I C_{R}=D_{3} R & \mathrm{~A}_{2}, \mathrm{D}_{3} \text { e } \mathrm{D}_{4}=\text { constantes (Anexo A). }
\end{array}
$$


Kume e Montgomery, citados por Fernandes (2000), afirmam que o processo está sob controle quando os pontos plotados na carta ocorrem dentro dos limites e que as variações existentes são devidas a causas comuns dentro do sistema, seguindo padrões normais de comportamento e que podem ser controladas por mudanças no próprio sistema. Entretanto, pontos plotados fora dos limites de controle, estão sofrendo a influência de causas externas ao sistema, uma vez que se está utilizando apenas números médios, desprezandose os extremos. Estas causas são imprevisíveis, merecendo investigação da gerência ao setor operacional, conduzindo a problemas como erro humano, quebra de ferramentas, acidentes, entre outras.

Para Schierz (1999), a interpretação dos gráficos de controle deve analisar conjuntamente os gráficos de amplitudes e médias. Primeiramente, analisa-se o gráfico de amplitudes, pois mostra a variação dentro das amostras e é um bom indicador de dispersão ou desvio padrão, em seguida, analisa-se o gráfico de médias, uma vez que a média de um determinado número de amostras é bastante sensível às mudanças que podem ocorrer no processo. Assim, o autor define que há quatro possíveis situações para interpretação dos gráficos:

1. Se R "sob controle" e x "sob controle", há um bom desempenho no processo;

2. Se R "sob controle" e x "fora de controle", o desempenho do processo foi afetado por uma causa especial. Deve-se, portanto, buscar a causa de cada ponto fora de controle e solucionar o problema;

3. Se R "fora de controle" e x "sob controle", a variação dentro das amostras não é puramente casual. Deve-se procurar a causa de tal variabilidade;

4. Se R "fora de controle" e x "fora de controle", o processo está fora de controle, devendo-se re-estudar o processo. 
Dellaretti Filho (1994), apresenta o gráfico seqüencial, uma alternativa mais simples de gráficos de controle, mas que fornece informações adequadas ao propósito pretendido. Assim, gráficos seqüenciais são gráficos dos dados ao longo do tempo, os quais evidenciam tendências temporais.

A interpretação destes gráficos seqüenciais deve se basear em seu aspecto global, verificando suas tendências ou a existência de pontos que se desviam dos demais. Portanto, um processo fora de controle é caracterizado pela presença de problemas ocasionais e suas causas devem ser identificadas e bloqueadas. Os tipos mais comuns de tipos de padrão de variação de processos fora de controle, segundo Dellaretti Filho (1994), são:

- Tendência ascendente ou descendente em pontos consecutivos, evidenciando alteração regular progressiva na média da característica da qualidade. Suas causas podem ser oriundas de desgaste de ferramentas, mudanças ambientais ou de parâmetros do processo e deterioração gradual dos equipamentos;

- Mudança brusca na média da característica da qualidade, o que pode ser causada por mudança intencional ou não, nas condições operacionais, uso de matéria prima diferente, operários ou métodos diferentes;

- Variação periódica formando ciclos que se repetem, senso que suas possíveis causas podem ser alterações sazonais da matéria prima, ocorrência de eventos psicológicos, ambientais, físicos, químicos ou mecânicos;

- Alteração brusca da amplitude de variação, sendo que seu aumento pode ser decorrente de operadores inexperientes ou utilização de matéria prima com maior variação e, a diminuição na amplitude explicase pela utilização de operadores mais experientes ou de matéria prima de melhor qualidade;

- Alteração gradual na amplitude de variação, oriunda de fatores como alteração na habilidade do operador, por motivos de fadiga ou 
desatenção, utilização gradual de matéria prima de diferentes qualidades, ausência de métodos de manutenção da qualidade;

- E, por fim, presença de pontos isolados, distantes da maioria dos dados, resultantes da ocorrência de erros de cálculos, instrumentos de aferição descalibrados, descontrole temporário dos parâmetros do processo ou amostras coletadas de processos diferentes.

De acordo com Pasqua (1999), é importante frisar que os limites de controle (LSC e LIC) são calculados com dados do próprio processo e, portanto, não tem nenhuma relação com os limites de especificação do processo (LSE e LIE). Logo, o processo pode estar sob controle, de acordo com os limites estatísticos, porém não indica necessariamente que o processo atende às expectativas atribuídas ao processo.

Assim, todo processo produtivo é um agregado de causas de variações, as quais são os maiores inimigos da qualidade, uma vez que originam perdas, erros e falhas. Os resultados específicos da operação analisada podem estar ou não em conformidade com as especificações, considerando-se que a variabilidade existente é aceitável de acordo com a amplitude dos padrões previamente estabelecidos (Vieira, 1999; Pasqua, 1999).

\section{- Histogramas:}

Os histogramas permitem a visualização, sob a forma de um gráfico de barras, a freqüência com que certos eventos ocorrem (distribuição de freqüências), além de inferir o quanto de variação existe no processo avaliado (Pasqua, 1999).

Segundo Dellaretti Filho (1994), um histograma pode ser definido como um gráfico de barras que associa os valores de uma característica de qualidade, divididos em pequenos intervalos, com a freqüência com que ocorrem na amostra. Seu objetivo principal é resumir um grande conjunto de 
dados, ressaltando-se suas características, como faixa de valores observados, dispersão e padrão de variação, permitindo rápida compreensão dos resultados.

Um histograma típico deve apresentar distribuição do tipo normal, na qual a maioria dos dados concentra-se em torno da medida central e um número semelhante de medidas situa-se de cada lado deste ponto. Outras configurações de um histograma podem representar a mistura de dados ou um controle desigual dos limites, resultando em histogramas dos tipos: assimétrico e com apenas um pico, assimétrico com queda acentuada em um de seus lados, assimétrico com dois picos, platô ou achatado e pico isolado (Dellaretti Filho, 1994 e Fernandes, 2000).

\subsubsection{Controle da qualidade na agricultura}

De acordo com Pasqua (1999), sob o ponto de vista técnico, qualidade na agricultura é a realização de operações agrícolas ou a obtenção de produtos que se adaptem às especificações ou aos padrões agronômicos recomendados. Sob o ponto de vista econômico, qualidade é a produção de serviços e de produtos a um custo compatível com a atividade e que satisfaçam as necessidades dos consumidores. Já no ponto de vista humano, qualidade representa as condições ideais para a realização do trabalho, possibilidades de desenvolvimento pessoal e profissional e estabilidade de emprego. Por fim, sob o ponto de vista ambiental, qualidade seria a realização de serviços e a obtenção de produtos de maneira sustentável, utilizando adequadamente os recursos naturais, de modo que sejam preservados.

$\mathrm{Na}$ agricultura, uma vez que a cultura já tenha sido implantada, qualquer operação realizada fora dos padrões planejados traz inúmeras perdas, já que deve ser reparada ou realizada novamente. Obviamente, deve-se então, lançar 
mão do conceito de prevenção, a fim de se verificar os resultados da operação ao longo de sua execução, quando ainda é passível de correção (SENAI, 1987).

Para Peche et al. (1994), as operações agrícolas são interdependentes, de forma que sempre haverá uma operação fornecedora, a qual deve ser realizada da melhor forma possível a fim de se atender plenamente às necessidades da operação cliente. Portanto o controle da qualidade em operações agrícolas é a adoção de um conjunto de procedimentos que produzam serviços e resultados, atendendo com precisão, as exigências da operação seguinte. Assim, para o autor, amostragens periódicas permitem que o processo seja analisado e ajustado conforme a necessidade, diminuindo-se as falhas e o re-trabalho, o que contribui, portanto, para obtenção de altas produtividades.

De acordo com Dodson (1998), sob o ponto de vista agronômico, qualidade é a realização de operações agrícolas ou a obtenção de produtos que se adequem às especificações ou aos padrões agronômicos recomendados.

Antunes \& Engel (1999), relatam os motivos pelos quais as empresas agrícolas devem adotar a qualidade total, citando entre os principais motivos a demanda por qualidade de vida, mudanças nas exigências do cliente, aumento da competição de mercado, necessidade de diferenciação de produtos e inversão da relação oferta $x$ demanda.

Bonilla (1995), afirma que com o uso de ferramentas estatísticas de controle da qualidade (CEP - Controle Estatístico do Processo), pode-se localizar as variações ou oscilações nas operações agrícolas a tempo de minimizar a possibilidade de concretização das mesmas fora do padrão de qualidade especificado, o que garante a imediata eliminação de defeitos e aumento de produtividade.

Portanto, de modo geral, a implantação da gestão pela qualidade e o uso de ferramentas estatísticas na agricultura, permitem à administração tomar medidas ágeis e racionais, embasadas em resultados científicos, garantindo o melhor aproveitamento dos equipamentos e máquinas agrícolas, da mão de obra e dos demais fatores de produção (Brassard, 1985). 


\subsubsection{Controle de qualidade em operações agrícolas mecanizadas}

Pasqua (1995), empregou técnicas estatísticas de controle de qualidade em operações mecanizadas para a cultura de milho, obtendo para um estudo de caso de semeadura, que o espaçamento entre sementes apresentava um índice médio de qualidade de $62,4 \%$, ou seja, 37,6 \% dos espaçamentos estavam fora dos padrões desejados. Ainda no estudo de caso da semeadura, a autora estudou a profundidade das sementes e verificou uma alta variação, ocorrendo desde sementes expostas até sementes a $8,5 \mathrm{~cm}$ de profundidade, 0 que acarreta desuniformidade de emergência, irregularidade de estande e queda na produção final. No estudo da operação de adubação nitrogenada, a autora constatou a variação de $11 \%$ na vazão do adubo ao longo do dia, gerando desperdícios e elevação dos custos. Por fim, a autora estudou a aplicação de inseticida e pôde verificar a variação de 80 \% entre a vazão máxima e a mínima dos bicos, o que comprova o alto desgaste do equipamento e, mais uma vez, maior ônus da operação. Como considerações gerais, tem-se a elevação dos custos propiciada pela realização de operações agrícolas fora dos padrões desejados, a criação de ferramentas práticas para o controle da qualidade e a importância do treinamento dos operadores, tornando-os responsáveis pela manutenção da operação dentro dos padrões desejados.

Lopes et al. (1995) trabalhou com o desenvolvimento de uma metodologia para determinação de padrões de qualidade em operações agrícolas mecanizadas na cultura de cana-de-açúcar, através de um programa que incluía treinamento e conscientização de operadores e uso do controle estatístico de processos (CEP) para análise dos dados. O autor descreveu todas as operações mecanizadas do processo de produção de cana e estabeleceu a relação "cliente-fornecedor" entre elas. Em seguida os operadores definiram os defeitos das operações anteriores que afetavam o desempenho de sua operação, obtendo-se os pontos críticos para cada etapa do processo produtivo. Os parâmetros definidos pelo trabalho foram 
profundidade do sulco, espaçamento entre sulcos e quantidade de impurezas minerais entregues a indústria. Os resultados indicaram que a profundidade do sulco estava acima da desejada pela empresa e que os espaçamentos entre sulcos estavam sendo afetados por causas especiais ao processo, como operadores despreparados, equipamentos desgastados e mal regulados e problemas no preparo da área. Com relação às impurezas entregues a indústria, o controle já apresentava bons resultados, reduzindo em $20 \%$ o índice de impurezas comparando-se duas safras de amostragens. Como conclusão, o autor creditou esta redução ao retorno da informação para o campo, conscientizando os operadores da importância da qualidade de seu trabalho e, de forma geral, a inclusão de processos de controle da qualidade resultou em ganho de eficiência e redução de custos.

Empregando conceitos estatísticos de controle da qualidade e análise dos custos de sistemas mecanizados para a cultura do milho, Dodson (1998) obteve em seus resultados que a operação de semeadura possuía 73 \% de sua área dentro das especificações e que, os $27 \%$ restantes, provocaram uma redução de $1 \%$ na receita líquida monetária por hectare. Além do aspecto econômico, o trabalho também demonstrou que a lavoura desenvolveu-se de forma irregular, favorecendo o surgimento de plantas daninhas e redução da produtividade.

Avaliando a qualidade de operações agrícolas em culturas anuais, Schierz (1999), concluiu que na operação de semeadura, a profundidade das sementes atingiu um bom padrão de qualidade, o índice de sementes por metro linear e distância entre sementes ficaram fora dos padrões desejados e que as amostragens periódicas ajudam a manter as operações dentro dos padrões.

Fernandes et al. (2000), aplicou o controle estatístico de processos na avaliação da qualidade de operações agrícolas mecanizadas para a cultura de cana-de-açúcar, envolvendo o preparo de solo e a aplicação de defensivos. Os indicadores de qualidade, profundidade de subsolagem e concentração média de gotas por área, foram definidos pelo corpo técnico da empresa avaliada e os padrões de qualidade (limites de especificação) foram determinados com base 
em critérios agronômicos para atender a cultura de cana-de-açúcar. Como resultados, o autor destacou que a operação de subsolagem estava sob controle estatístico, porém acima do limite superior de especificação da empresa, agregando maior custo ao sistema de produção, bem como diminuição da capacidade operacional das máquinas. Para a aplicação de defensivos, os resultados apontaram que $54 \%$ da área amostrada apresentava deposição de gotas acima do desejado, o que também acarretava em maiores custos, sendo esta aplicação excessiva atribuída às condições climatológicas e a deficiências de regulagem do pulverizador na hora de aplicação. Como conclusão o autor apontou a eficiência do CEP na avaliação de operações agrícolas e o vislumbramento da redução de custos com o seu uso.

Milan \& Fernandes (2002), utilizaram técnicas de controle de qualidade em operações agrícolas mecanizadas na cultura do milho para produção de silagem, destacando o desenvolvimento de padrões e dispositivos para aferições da qualidade nas operações. Em seu trabalho, os autores selecionaram duas áreas com características físicas semelhantes, deixando que na primeira, as operações fossem realizadas sem qualquer interferência e na segunda área, o autor aplicou os padrões desejados, regulou os equipamentos e acompanhou o trabalho, realizando correções quando necessário. Como conclusão, o estudo apontou a adequação das ferramentas criadas para medição dos parâmetros e com o uso do controle de qualidade, a operação de preparo de solo tornou-se mais eficiente, reduzindo-se o tamanho de torrões. Também houve melhor distribuição de plantas no talhão controlado por técnicas de qualidade, de forma que de modo geral, as plantas deste talhão obtiveram um melhor desenvolvimento, com maiores alturas e melhores relações entre peso das folhas e peso das plantas de milho.

Fessel (2003) avaliou as atividades de preparo mecanizado de solo e de plantios manual e mecanizado de eucaliptos utilizando ferramentas da qualidade, como histogramas, diagrama de causa e efeito e gráficos de Pareto e de controle. Os itens de preparo de solo avaliados foram: profundidade do 
sulco, diâmetro dos torrões e volume cilíndrico dos galhos de madeira deixados sobre a faixa de sulcamento. Para a atividade de plantio, os itens avaliados foram: presença de defeitos da operação, distância entre plantas, altura da parte aérea das mudas e sobrevivência das plantas após um mês de idade. Como conclusão, o autor obteve que a qualidade em ambos os sistemas de plantio não variaram dentro dos padrões aceitáveis pela empresa, porém o custo do sistema mecanizado foi $44,9 \%$ superior ao custo do sistema manual de plantio, devido à baixa capacidade operacional observada no sistema mecanizado.

\subsection{Agricultura de precisão e instrumentação}

Leal (2002) argumenta que a Agricultura de Precisão pode ser uma das recentes tecnologias a serem empregadas na batalha competitiva do processo de globalização, pois permite o monitoramento da variabilidade espacial das culturas, visando a otimização da produção agrícola, a minimização de impactos ambientais e a redução de custos. O autor destaca que no Brasil, a Agricultura de Precisão está sendo adotada gradativamente, revolucionando o modo de gerenciamento das propriedades rurais.

Segundo Goering (1992) a Agricultura de Precisão tem sido cada vez mais utilizada, motivada por razões ambientais e econômicas e viabilizada pelo desenvolvimento tecnológico, propiciando um novo enfoque ao gerenciamento da atividade produtiva agrícola.

O Sistema de Posicionamento Global (GPS) foi desenvolvido pelo Departamento de Defesa dos EUA e no meio agrícola, é associado à Agricultura de Precisão. O GPS é um equipamento que permite a localização georeferenciada do usuário. Em sua estrutura final o sistema conta com uma constelação de 24 satélites (21 mais 3 de reserva), distribuídos em 6 órbitas distintas, a um altura de 20 mil quilômetros. Os sinais emitidos pelos satélites 
são caracterizados por certo número de componentes, apresentando a seguinte estrutura: ondas portadoras L1 e L2; moduladas, em fase com as portadoras; os códigos CIA (Coarse Acquisition Code) e P (Precision Code). Mas 0 Departamento de Defesa dos EUA restringiu o uso do código $P$ à fins militares, sobrepondo ao mesmo uma nova modulação, o código $\mathrm{Y}$; conhecido como AS (Anti-spoofing). Além do AS o Dep. De Defesa decidiu por uma outra restrição, o Selective Availability (AS); incluindo um erro proposital nas mensagens enviadas pelos satélites, mas há uma técnica específica de posicionamento, o DGPS (Differential Global Position Sistem), o qual tem por finalidade eliminar os efeitos sistemáticos dos erros impostos (Balastreire, 2000)

Han et al. (1994) enfatiza que a Agricultura de Precisão traz um novo significado ao gerenciamento da produção agrícola, fundamentando-se na existência da variabilidade espacial dos fatores de produção. Desta forma, a área agrícola passa a ser vista como uma somatória de pequenas sub-áreas, as quais devem ser tratadas individualmente a fim de que a rentabilidade econômica de cada uma delas possa ser explorada ao máximo.

Fundamentalmente a Agricultura de Precisão é um jogo de ações que busca reduzir as insuficiências na produção agrícola e aumentar o retorno do produtor. A adoção de técnicas de Agricultura de Precisão só faz sentido quando o produtor estiver fazendo todo o esforço para melhorar a eficiência da produção agrícola. Ineficiências identificadas através de técnicas de Agricultura de Precisão incluem os fatores limitantes e a aplicação excessiva de insumos de produção (Balastreire, 2000).

Assim como Steven e Milar (1999) concluem, a Agricultura de Precisão visa adequar a administração agrícola às condições variadas encontradas nos campos.

Para Clark \& Mcguckin (1996), sob uma visão instrumental, a Agricultura de Precisão é um processo de inclusão de eletrônica nos equipamentos agrícolas, envolvendo sistemas automatizados, basicamente compostos por 
micro-controladores, sensores e atuadores, acoplados ao implemento agrícola pré-existente e interligado ao sistema de posicionamento global.

A eletrônica embarcada pode ser aliada na instrumentação de máquinas agrícolas, sendo definida como todo equipamento eletrônico associado às suas partes mecânicas, a fim de proporcionar melhores eficiências operacionais, bem como armazenamento de dados de operação para futuras análises do desempenho operacional das atividades executadas (Mialhe, 1996). 


\section{MATERIAL E MÉTODOS}

\subsection{Caracterização do local do trabalho e do sistema de produção avaliado}

A empresa selecionada para a avaliação proposta por este trabalho possui sua propriedade sede localizada no município de Água Comprida, estado de Minas Gerais e uma segunda propriedade no município de Guaíra, estado de São Paulo. As propriedades têm o seu sistema produtivo voltado essencialmente à cultura do feno, possuindo um total de seis pivôs centrais para irrigação e sistemas de fenação totalmente mecanizados.

A coleta de dados a campo foi realizada essencialmente na propriedade localizada no município de Água Comprida, localizada sob as coordenadas $19^{\circ}$ $56^{\prime} 45^{\prime \prime} S$ de latitude e $48^{\circ} 02^{\prime} 15^{\prime \prime} \mathrm{W}$ de longitude.

A área total da propriedade é 1.014,86 ha, dos quais cerca de 809 ha são destinados à cultura do feno, dividindo-se em 247 ha irrigados por pivô central e 562 ha de sequeiro. O mapa da propriedade, com as respectivas divisões em talhões, pode ser visualizado no Anexo B.

Segundo Prado (1997), a região de Uberaba apresenta solos de textura muito argilosa, classificados como latossolo vermelho-escuro. A topografia da região pode ser caracterizada como plana, suavemente ondulada, de forma que a propriedade apresenta as mesmas características.

De acordo com a classificação de Köppen, o clima da região pode ser classificado como Aw, isto é, clima tropical úmido, com verão chuvoso e inverno seco. Precipitação média anual entre 1200 e 1500 mm e temperaturas médias entre 21 e $22^{\circ} \mathrm{C}$ (Sentelhas et al., 1999). 
O sistema produtivo da propriedade baseia-se em sua maior parte, nas forrageiras do gênero Cynodon. As espécies cultivadas nas áreas de produção são Tifton-85, com talos intermediários e Coast cross, com talos mais finos. Estas espécies possuem bom valor nutritivo e proporcionam um produto final de alta qualidade, uma vez que apresentam talos adequados ao processo de fenação e, portanto, reduzido diferencial de desidratação entre folhas e caules, resultando em um curto tempo de secagem (Silva et al., 1998).

O fluxograma da Figura 1 mostra que o processo de colheita do feno é constituído por sete sub-operações, realizadas simultaneamente, por um conjunto de diferentes tipos de máquinas.

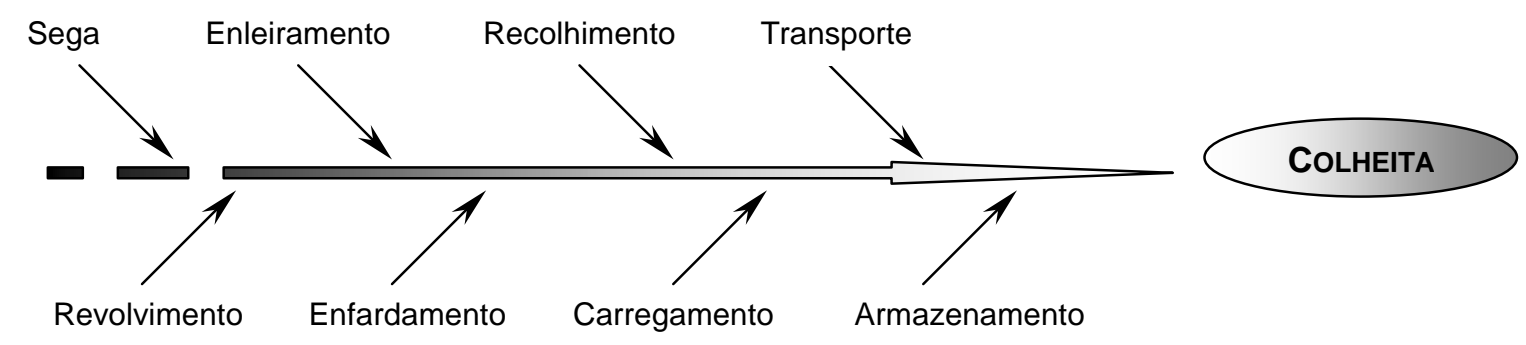

Figura 1 - Fluxograma da seqüência de sub-operações realizadas na fenação

Todas estas sub-operações estão descritas no Anexo C, onde foi montado o fluxograma da seqüência de operações realizadas pela propriedade avaliada em seu sistema de produção, bem como todas as atividades e seus requisitos necessários para a realização do processo de fenação.

A empresa produz fardos com dimensões de $1,20 \mathrm{~m}$ de comprimento, $0,45 \mathrm{~m}$ de largura e 0,37m de altura, com peso entre 35 e $40 \mathrm{~kg}$.

A qualidade do produto segue a seguinte classificação:

* Feno Tipo A: - coloração verde e por volta de $70 \%$ de folhas;

- umidade entre 13 e $17 \%$;

- até 4 dias entre corte e enfardamento. 
* Feno Tipo B: - coloração amarelada, com menos folhas e mais talos;

- umidade entre 13 e $17 \%$;

- de 1 a 10 dias entre corte e enfardamento ou com ocorrência de chuva .

* Feno Tipo C: - ponto de palha, destinado apenas à moagem e compor rações animais.

Tabela 1. Composição nutricional dos produtos segundo a classificação da propriedade avaliada

\begin{tabular}{lcc}
\hline & Feno Tipo A & Feno Tipo B \\
\hline Matéria Seca & 83 a $87 \%$ & 83 a $87 \%$ \\
Proteína Bruta & 12 a $14 \%$ & 9 a $11 \%$ \\
N.D.T. & $60 \%$ & $57 \%$ \\
\hline NDT: Nutriente Digestível Total &
\end{tabular}

\subsection{Identificação das operações críticas}

\subsubsection{Caracterização do desempenho operacional e econômico do sistema mecanizado de fenação}

O desempenho operacional do sistema mecanizado de fenação foi obtido pelo acompanhamento das sete sub-operações. Primeiramente foram coletados os dados pertinentes a cada conjunto mecanizado, como características ponderais.

Cada sub-operação do sistema de colheita, realizada por um conjunto mecanizado, foi acompanhada e coletado os dados necessários. Primeiramente selecionava-se um trecho homogêneo (altura de plantas, umidade, relevo) da área que seria trabalhada naquele determinado dia, sem que ocorressem interferências do agente coletor de dados ao sistema, de forma que o transcorrer da operação fosse o mais próximo da realidade habitual de trabalho. 
Assim, esta área pré-determinada era medida com o auxílio do hodômetro de uma moto Honda XLR 125, o qual foi aferido com marcações feitas com trena de PVC de $50 \mathrm{~m}$. Comparando-se o perímetro obtido pelo hodômetro com a trena, obteve-se valores bem próximos, com variações entre 1 e $2 \%$.

Selecionadas as áreas de medições, eram demarcados cinco trechos com $50 \mathrm{~m}$ de comprimento (devido à distância de $50 \mathrm{~m}$ entre as torres do pivô), medidos com trena em PVC, a fim de se levantar a velocidade média de deslocamento dos conjuntos mecanizados. Também foram medidas, com o auxílio da mesma trena, as larguras efetivas de trabalho para os cinco trechos selecionados para cada sub-operação.

A eficiência dos conjuntos mecanizados foi mensurada pelo estudo de tempos e movimentos, utilizando-se a metodologia descrita por Banchi et al (1994).

Tendo-se a largura, velocidade de trabalho e eficiência dos equipamentos para cada sub-operação de fenação, obteve-se a capacidade de campo operacional, segundo metodologia descrita por Mialhe (1974).

O cálculo do custo horário foi estruturado na metodologia descrita pela ASAE (2001), baseando-se nos valores dos equipamentos pagos pela propriedade, salário médio dos tratoristas, preço atual do combustível $\left(R \$ 1,50 . L^{-1}\right)$, juros de mercado (12\% ao ano), vida útil máxima de 10 anos e utilização média das máquinas de 350 horas anuais.

Desta forma, o custo operacional do sistema foi calculado pela divisão dos custos horários pela capacidade operacional, obtendo-se o custo individual para cada sub-operação podendo então, avaliar as operações mais críticas, sob o enfoque econômico, ao sistema produtivo. 


\subsubsection{Avaliação da qualidade das operações agrícolas mecanizadas}

Foram realizadas reuniões com a diretoria da empresa para a análise do processo de produção e a identificação das operações críticas, tendo como critérios a influência na qualidade final do feno.

Em consenso com o corpo técnico da empresa, foram definidos os indicadores que deveriam ser analisados em cada uma das sub-operações do processo de fenação e, para cada indicador definiram-se os padrões de qualidade a serem respeitados. Com base nestes critérios, foram selecionadas as operações de sega e enfardamento, para as quais foram definidos os limites de especificação, referentes aos indicadores das operações.

\subsection{Avaliação da qualidade das operações críticas}

\section{- Sega}

$\mathrm{Na}$ operação de sega foram avaliadas duas máquinas, uma de arrasto, marca Khun, modelo GMD300 acoplada a um trator New Holland, modelo TL100 e uma auto-propelida da marca Case, modelo 8850. Foi desenvolvida uma folha de verificação e a coleta de dados foi realizada através de uma amostra, a cada quinze minutos durante a jornada de trabalho, medindo-se a altura da planta ceifada em relação ao solo. As amostras foram obtidas em relação à largura de corte das segadoras, sendo cada uma delas composta de vinte pontos divididos em 4 colunas no sentido transversal ao deslocamento das máquinas e espaçados de 1,2 $\mathrm{m}$ e, cinco linhas espaçadas de $1 \mathrm{~m}$ no sentido longitudinal. Para a segadora Khun foram obtidas trinta e uma amostras e para a Case trinta e quatro. A jornada de trabalho, estipulada pela empresa, é de 9 horas diárias, mas ela pode ser alterada de acordo com as condições climáticas e a umidade da cultura, pois influem no processo. 


\section{- Enfardamento}

Para a operação de enfardamento, o equipamento utilizado foi uma enfardadora de fardos retangulares, de fabricação americana, marca Freeman, modelo 270, conforme mostrado na Figura 2. É uma máquina que necessita de uma fonte tratória (trator acima de $70 \mathrm{cv}$ ), porém seus sistemas mecânicos são independentes do trator, acionados por um motor estacionário de três cilindros, quatro tempos, sistema de arrefecimento a ar e sistema de transmissão com polia. As vantagens de se ter um motor estacionário na enfardadora é que sua tração pode ser realizada por qualquer tipo de veículo sem tomada de força, como uma camionete por exemplo, e também realizar o enfardamento estacionada próxima a secadores de feno, sem necessitar de qualquer tipo de veículo com tomada de força.

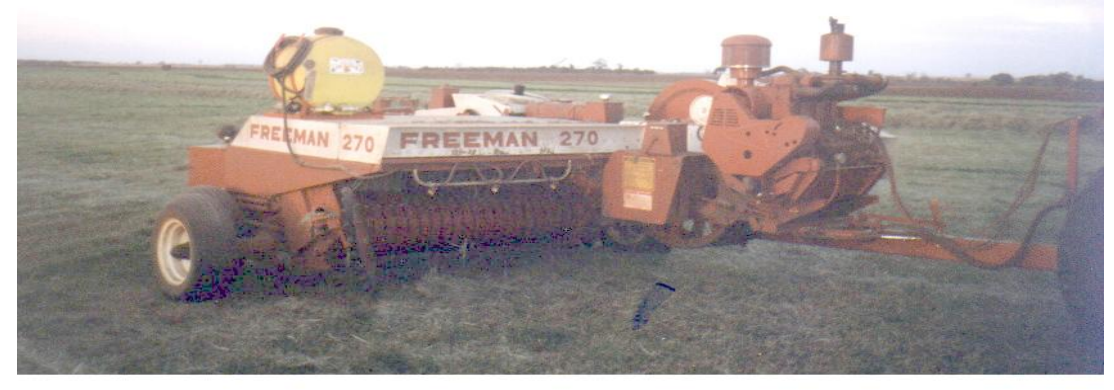

Figura 2 - Vista lateral da enfardadora instrumentada, onde pode ser visualizado seu motor e sistema recolhedor

A avaliação da operação de enfardamento ocorreu em 3 etapas:

- Contagem manual dos ciclos de prensagem;

- Desenvolvimento e introdução de sistema eletrônico de contagem dos ciclos de prensagem;

- Introdução de Sistema de Posicionamento Global e memória para armazenamento dos ciclos de prensagem ao sistema eletrônico de contagem dos ciclos de prensagem. 
Desta forma, para a etapa de avaliação do enfardamento através da contagem manual dos ciclos, as amostras foram coletadas a cada quinze minutos, totalizando vinte pontos amostrais. Para cada ponto, foi separada uma seqüência de cinco fardos, onde se determinou o número de ciclos da prensa da enfardadora e o comprimento dos fardos.

As amostras foram coletadas nos pivôs 1 e 3 (Anexo B), onde são cultivadas forrageiras do gênero Cynodon, variedades Tifton 85 e Coast Cross. Durante o período de amostragens, a produtividade média, em matéria seca (ms), do pivô 1 foi de 7,98 t de ms.ha ${ }^{-1}$ no talhão Tifton $A$ e 3,82 t. de ms.ha-1 no talhão Cross B. No pivô 3, a produtividade média foi de $6,95 \mathrm{t}$ de $\mathrm{ms}^{-h^{-1}}$.

Os materiais utilizados para coleta de dados referem-se basicamente aos equipamentos agrícolas e aos dispositivos de mensuração, como trena metálica com cinco metros e graduação até milímetros, trena plástica de 50 metros e graduação até centímetros, balança com graduação até 0,5 quilogramas e planilhas de campo.

Para a etapa de avaliação do processo de enfardamento utilizando o sistema eletrônico de contagem dos ciclos da enfardadora, as amostras foram coletadas no pivô 1, talhão $B$ (Anexo B), onde é cultivada forrageira do gênero Cynodon, variedade Tifton 85. Durante o período de amostragens, a produtividade média do talhão $B$ foi de $6,50 \mathrm{t}$ de $\mathrm{ms} \mathrm{ha}^{-1}$.

A metodologia para instrumentação e avaliação da enfardadora seguiu cinco etapas: a) desenvolvimento e implantação de um dispositivo eletrônico para controle do número de ciclos da prensa da enfardadora por fardo, b) avaliação da operação de enfardamento de acordo com a rotina de trabalho da propriedade, ou seja, sem controle eletrônico, determinando-se os parâmetros: quantidade de ciclos da prensa por fardo e formatação do fardo (altura, largura, comprimento interno e externo), c) utilizando-se os mesmos parâmetros anteriores, avaliação da operação de enfardamento sob condição controlada, pelo uso do sensor eletrônico de contagem do número de ciclos da prensa por fardo, onde o operador foi instruído sobre a importância da 
qualidade do serviço a ser realizado e treinado a utilizar o dispositivo eletrônico, d) verificação da correlação entre todas as características avaliadas, e) verificação se o número de ciclos por fardo, recomendado pelo fabricante, apresenta a melhor formatação do fardo e, se necessário, proposição do número de ciclos que resulte na formatação adequada.

Na operação de enfardamento um dos pontos críticos é a padronização do tamanho dos fardos, a fim de se facilitar as operações subseqüentes: recolhimento e estocagem. O número de quatorze ciclos de prensagem por fardo é recomendado como o ideal pelo fabricante do equipamento, para que se produzam fardos bem compactados e de boa conformação, ou seja, comprimento interno deve ser próximo do comprimento externo. Ambos comprimentos devem ser entre 1,18 e 1,22 metros, para que as operações subseqüentes possam ser realizadas adequadamente.

A coleta de dados ocorreu em dois dias, executando-se no primeiro a coleta de dados sem o controle eletrônico pelo operador, instalando-se o display na parte traseira do trator, de forma que apenas o apontador de campo pode acompanhar a contagem eletrônica do número de ciclos da prensa por fardo. No segundo dia de amostragem, o display do sistema eletrônico foi instalado ao lado do operador, no pára-lama direito do trator, onde já existe o controle de aceleração do motor da enfardadora. O operador foi instruído para o uso do sistema eletrônico de contagem e a coleta do número de ciclos da prensa por fardo foi realizada de forma controlada. Para os dois dias de coletas de dados, a amostragem ocorreu ao longo da jornada de trabalho, aleatoriamente, sendo avaliados cinco fardos por ponto, totalizando 20 pontos por dia. Para cada fardo amostrou-se o número de ciclos da prensa e seu formato final (comprimento interno e externo).

Os materiais utilizados para coleta de dados referem-se basicamente aos equipamentos agrícolas, sistema eletrônico de contagem do número de ciclos da prensa por fardo e aos dispositivos de mensuração, como trena metálica 
com cinco metros e graduação até milímetros, trena plástica de 50 metros e graduação até centímetros, planilhas de campo.

Por fim, pensando-se na melhoria potencial do sistema de contagem de ciclos de prensagem e controle mais efetivo do padrão de qualidade da operação, na etapa de avaliação na qual agregou-se o GPS e a memória para armazenamento dos dados, as amostras foram coletadas no pivô 2, talhão A (Anexo B), onde é cultivada forrageira do gênero Cynodon, variedade CoastCross. A produtividade média no talhão foi de 8,5 t de $\mathrm{ms} \cdot \mathrm{ha}^{-1}$.

A metodologia de instrumentação da enfardadora e avaliação do sistema eletrônico de contagem georeferenciado seguiu duas etapas: a) obtenção do perímetro da área a ser trabalhada usando o GPS do sistema; através de caminhamento pelo perímetro com o GPS, a cada 6 segundos era obtido um ponto referenciado, compondo o contorno da área. b) instalação do sistema na enfardadora Freeman 270 e acompanhamento de um turno de trabalho de quatro horas e trinta e sete minutos consecutivos, onde para todos os fardos produzidos, obteve-se o número de ciclos de prensagem e localização referenciada, totalizando 1825 pontos amostrais.

Devido ao grande número de pontos amostrados nesta etapa de avaliação da operação de enfardamento, os dados foram agrupados em intervalos de 15 minutos, totalizando 19 pontos amostrais.

Os materiais utilizados referem-se basicamente aos equipamentos agrícolas, sistema eletrônico de contagem georeferenciado e recursos de informática, como computador e softwares para análise dos resultados.

Para todas as etapas de avaliação do processo de enfardamento, os dados obtidos foram analisados através do uso do CEP, segundo Dellaretti Filho \& Drumond (1994) e Vieira (1999) sendo utilizados os gráficos de controle $(\mathrm{x}-\mathrm{R})$, que monitora a variação da média e amplitude de uma variável no tempo. O gráfico típico exibe o valor médio da característica da qualidade, o limite superior de controle (LSC) e inferior (LIC) e os valores especificados pela empresa (LSE, LIE). 
3.4 Desenvolvimento de eletrônica embarcada para controle dos indicadores de qualidade na operação de enfardamento

\subsubsection{Desenvolvimento de sistema eletrônico de contagem dos ciclos de prensagem dos fardos}

A enfardadora utilizada na propriedade possui motor próprio, de forma que seus sistemas rotativos são independentes do trator e, portanto, sua prensa trabalha a uma rotação fixa. Desta forma, o número de ciclos da prensa é em função do tempo e a regulagem do número de ciclos por fardo depende da velocidade de operação e da quantidade de massa vegetal contida na leira. Assim, leiras menores exigem maior velocidade de operação e leiras maiores, menor velocidade, a fim de se manter constante o número de ciclos de prensagem por fardo. Esta afirmação é melhor compreendida com a Figura 3, onde pode-se visualizar a leira e o sistema de alimentação da enfardadora trabalhando.

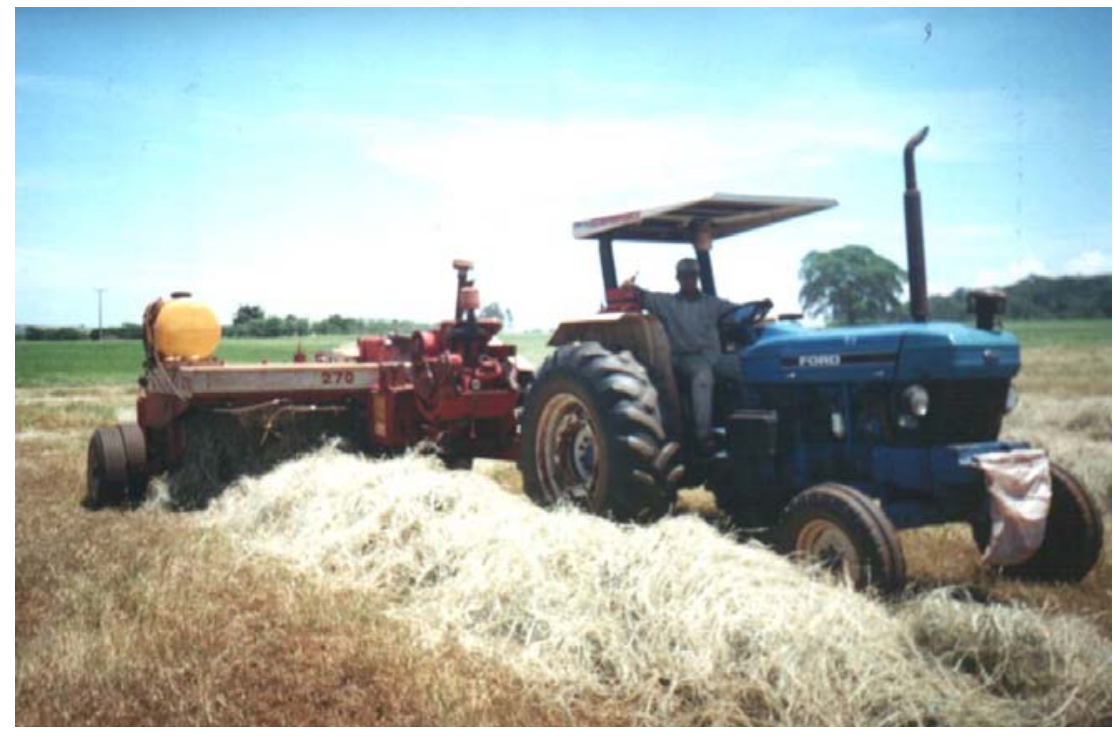

Figura 3 - Vista da leira e sistema alimentador da enfardadora Freeman 270 
Seguindo as recomendações de operação do fabricante da enfardadora e estudos realizados na propriedade, o número ideal de ciclos da prensa por fardo, seria de 14 ciclos, porém não existia qualquer dispositivo eletrônico ou mecânico que controlasse esta característica da máquina, restando ao operador o controle através de contagem mental do número de ciclos da prensa por fardo. Assim, na definição dos limites de especificação houve uma maior flexibilidade deste número, fixando o limite inferior em 12 ciclos e o superior em 16 ciclos.

No desenvolvimento do sistema eletrônico de contagem optou-se por utilizar tecnologia micro-processada e display de cristal líquido (LCD), o qual pode trabalhar em condições de incidência de luz solar extremas. Com o uso de tecnologia micro-processada, pôde-se agregar a contagem instantânea do número de ciclos, a contagem acumulada dos cinco últimos fardos produzidos e o alerta sonoro, que dispara quando a operação está sendo realizada fora dos padrões estabelecidos (entre 12 e 16 ciclos por fardo).

O sistema eletrônico é dependente dos pulsos enviados pelos sensores indutivos instalados nos sistemas mecânicos da enfardadora. Os pulsos de contagem são captados por um sensor instalado no sistema de prensagem da enfardadora, como pode ser visto na Figura 4.

A

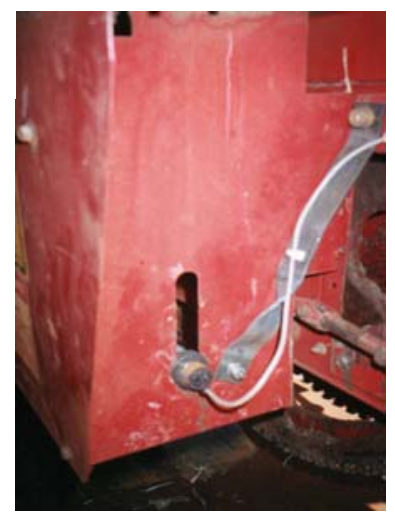

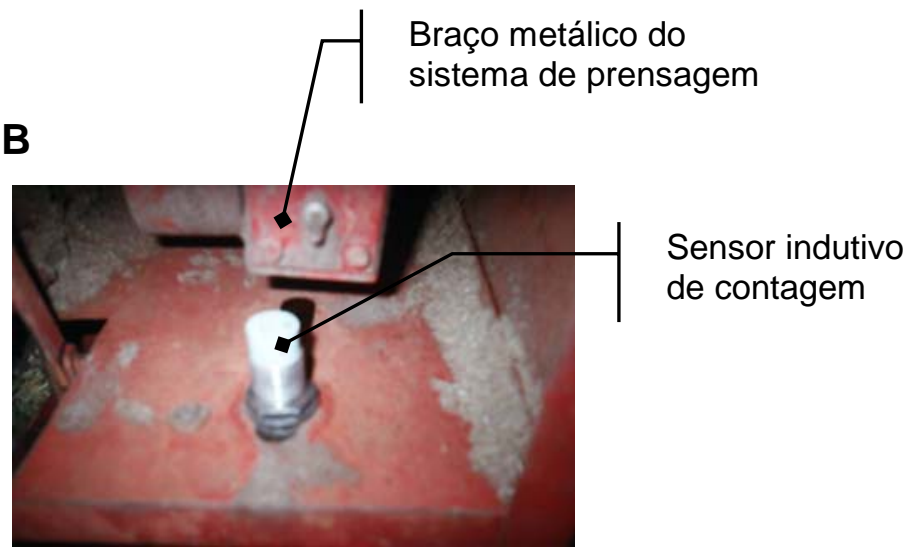

Figura 4 - (A) Vista externa do local de instalação do sensor de contagem dos ciclos da prensa na enfardadora Freemam; (B) Vista interna do local de instalação do sensor de contagem 
Na Figura 4 (B) pode-se visualizar o sensor indutivo, onde a cada passada do braço metálico da prensa é contado um pulso, referente à prensagem para formação do fardo.

A totalização dos pulsos de contagem por fardo é realizada por outro sensor indutivo instalado no sistema de amarração da enfardadora, o qual a cada pulso, encerra a contagem do fardo produzido e envia um novo sinal para o sistema iniciar uma nova contagem. O local de instalação deste sensor de "reset" pode ser visualizado na Figura 5.

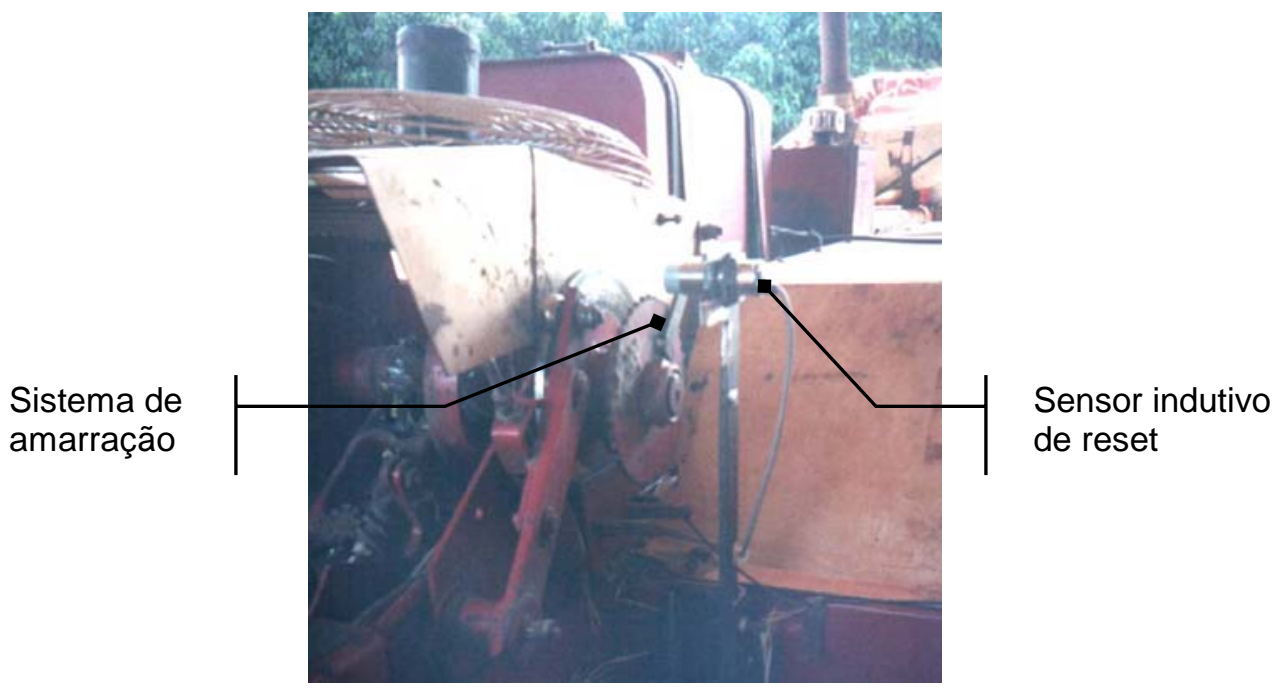

Figura 5 - Vista do local de instalação do sensor de "reset" no sistema de amarração da enfardadora

\subsubsection{Sistema eletrônico de contagem com introdução do GPS}

Após a introdução do sistema de contagem dos ciclos de prensagem por fardo na enfardadora Freeman, vislumbrou-se a oportunidade de se acoplar um sistema de posicionamento global (GPS) ao sistema, com o intuito de realizar um acompanhamento minucioso dos ciclos de prensagem ao longo da jornada de trabalho e localizar os fardos no campo. 
A intenção de se acompanhar a contagem dos ciclos de prensagem surgiu pela importância que este indicador apresentou à qualidade final do fardo. Portanto, o intuito deste acompanhamento foi exatamente conferir se ocorre variação da característica da qualidade ao longo dia.

Já a localização dos fardos teve por objetivo iniciar um trabalho de descrição da variabilidade de produtividade da forrageira nos campos de fenação da propriedade.

Desta forma, introduziu-se um sistema eletrônico microcontrolado para indicação e coleta de dados via GPS, ao sistema de contagem dos ciclos de prensagem previamente desenvolvido. Todo o sistema é gerenciado por um microcontrolador de 8 bits da empresa Microchip.

A antena e o módulo receptor são responsáveis pela captação dos sinais de GPS e formatação dos dados para o padrão NMEA 0183, que são então enviados ao microcontrolador, o qual está programado para codificar e tratar este sinal de maneira adequada. $O$ módulo de processamento do sistema eletrônico de contagem dos ciclos e a antena receptora do GPS podem ser visualizados na Figura 6.

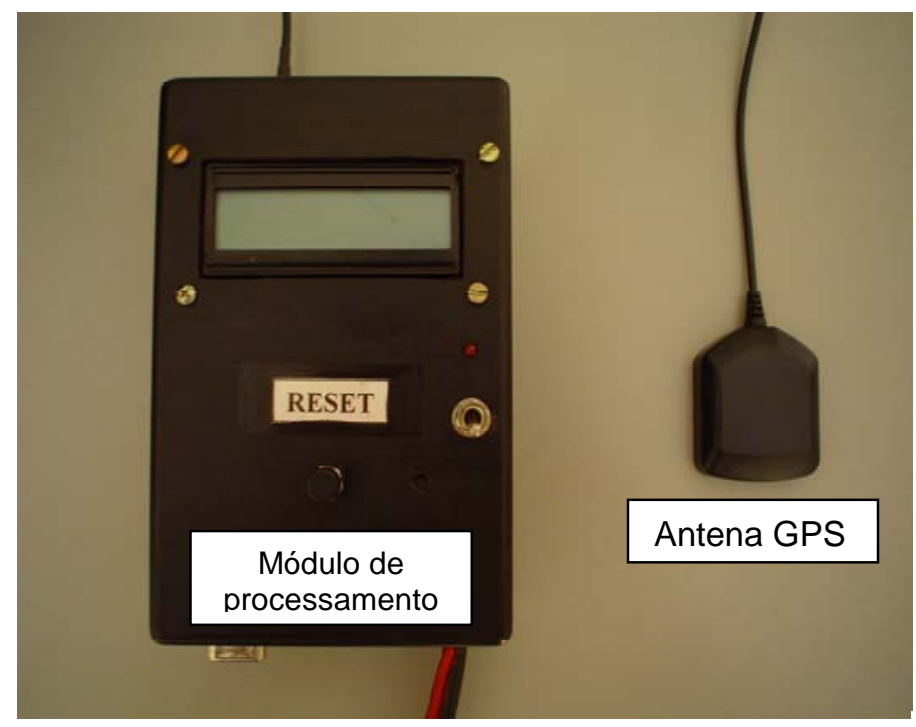

Figura 6 - Módulo de processamento do sistema eletrônico de contagem dos ciclos de prensagem e antena do GPS 
Dentre vários tipos de sentenças enviadas pelo GPS no padrão NMEA, o microcontrolador filtra os dados da sentença GGA, da qual extrai as informações necessárias para a aplicação em questão.

O microcontrolador trata estas informações junto com as informações dos sensores de fardo e ciclo de prensagem e, através de um display tipo LCD, faz a interface com o usuário mostrando alguns dados como posição, fardo atual e anterior, além do menu de opções, o qual permite exportar os dados para um computador tipo IBM PC. Uma interface RS232 permite que os dados sejam exportados para qualquer modelo de computador sem nenhum risco de incompatibilidade, desde que sejam respeitadas as taxas de transferência, bem como as características do protocolo.

As características técnicas e o fluxograma do sistema eletrônico de contagem acoplado ao GPS podem ser visualizados nos Anexos D e E, respectivamente.

Com a introdução do GPS ao sistema eletrônico de contagem, todos os fardos passaram a ser amostrados, uma vez que a cada fechamento de fardo são armazenadas as coordenadas geográficas e o número de ciclos de prensagem referentes ao fardo.

O processo de tratamento e visualização dos dados iniciou com o descarregamento dos dados armazenados no módulo de processamento do sistema para um computador portátil utilizando o software Trackmaker e exportados para Microsoft Excel. A tabela foi então exportada para o software SSToolBox (Dev Group) ${ }^{\circledR}$ e foi criado o mapa de visualização dos pontos georeferenciados. As coordenadas geográficas coletas pelos GPS foram convertidas para coordenadas métricas (UTM), permitindo assim o cálculo das distâncias entre os pontos.

O peso dos fardos foi obtido pela pesagem de todas as carretas de transporte das pilhas de feno antes do armazenamento. Assim, foi utilizada uma balança rodoviária, a qual foi tarada para que houvesse o desconto do peso da 
carreta e o peso obtido foi divido pela capacidade de carga das carretas, 201 fardos, obtendo-se o peso médio dos fardos.

Tendo-se o peso médio para cada seqüência de amostragem de 201 fardos georeferenciados, desenvolveu-se um algoritmo, onde a partir da distância entre os fardos e do espaçamento entre linhas que define a área de contribuição de cada fardo, determinou-se a produtividade individual de cada uma dessas áreas. As áreas representativas de cada ponto foram obtidas pela multiplicação das distâncias entre fardos pela largura de corte de cada leira, equivalente a 5,53 m (largura de trabalho do ancinho enleirador). Para melhor ajuste de posicionamento das coordenadas da área representada por cada fardo, esses pontos foram recuados para o centro dos polígonos, com base nas arestas entre pontos. Para obter o calculo da produtividade, utilizou-se o critério da multiplicação da área de produção do ponto pelo peso médio de cada fardo. 


\section{RESULTADOS E DISCUSSÃO}

\subsection{Operações críticas}

\subsubsection{Desempenho operacional e econômico do sistema mecanizado de fenação}

As limitações climáticas e a necessidade de um rápido processo de fenação para se garantir a qualidade final do produto, obrigam que o sistema mecanizado de colheita da propriedade seja ágil e eficiente e que, portanto, seja constituído por máquinas novas e de alta tecnologia, o que mobiliza elevado capital financeiro.

A avaliação do desempenho operacional do sistema mecanizado torna-se importante nesta avaliação, uma vez que através dele pode-se conhecer as deficiências das sub-operações e apontar os pontos críticos mais relevantes economicamente ao sistema.

O estudo de eficiência e desempenho operacional dos conjuntos mecanizados utilizados nas sub-operações de fenação seguiu metodologia

proposta por Banchi et al. (1994) e Mialhe (1996), respectivamente. Para a análise econômica do sistema mecanizado de fenação foram consideradas todas as sub-operações, especificando-se a cada uma delas o custo operacional calculado segundo as normas da ASAE (2001a).

A Tabela 02 descreve os resultados da avaliação do desempenho operacional e econômico do sistema mecanizado de fenação para a propriedade analisada. 
Tabela 2. Desempenho operacional e econômico dos conjuntos mecanizados, para as sub-operações de fenação

\begin{tabular}{|c|c|c|c|c|c|}
\hline Sub-operação & $\begin{array}{l}\text { Equipamento } \\
\text { necessário }\end{array}$ & $\begin{array}{c}\text { Tipo I } \\
\text { Modelo }\end{array}$ & $\begin{array}{l}\text { Eficiência } \\
(\%)\end{array}$ & $\begin{array}{c}\text { Capacidade } \\
\text { operacional } \\
\text { efetiva }\end{array}$ & $\begin{array}{c}\text { Custo da } \\
\text { sub-operação } \\
\left(\mathrm{R} \$ \mathrm{ha}^{-1}\right) \\
\end{array}$ \\
\hline \multirow[t]{2}{*}{ Sega } & $\begin{array}{l}\text { Segadora } \\
\text { autopropelida }\end{array}$ & Case 8850 & 78 & 2,1 ha. $\mathrm{h}^{-1}$ & 44,9 \\
\hline & $\begin{array}{l}\text { Trator+ } \\
\text { Segadora } \\
\text { de arrasto }\end{array}$ & $\begin{array}{l}\text { TL } 100 \\
\text { Case } 8312\end{array}$ & 78 & 2,2 ha. $\mathrm{h}^{-1}$ & 35,3 \\
\hline Revolvimento & $\begin{array}{l}\text { Trator+ } \\
\text { Ancinho } \\
\text { revolvedor }\end{array}$ & $\begin{array}{l}\text { TL } 80 \\
\text { CLAAS }\end{array}$ & 95 & 5,0 ha. $h^{-1}$ & 8,6 \\
\hline Enleiramento & $\begin{array}{l}\text { Trator+ } \\
\text { Ancinho } \\
\text { enleirador }\end{array}$ & $\begin{array}{l}\text { TL } 80 \\
6 \text { rotores }\end{array}$ & 79 & 4,3 ha. $\mathrm{h}^{-1}$ & 9,9 \\
\hline Enfardamento & $\begin{array}{l}\text { Trator+ } \\
\text { Enfardadora }\end{array}$ & $\begin{array}{l}\text { TL70 } \\
\text { Freeman } 270\end{array}$ & 80 & 2,7 ha. $\mathrm{h}^{-1}$ & 31,7 \\
\hline Recolhimento & $\begin{array}{l}\text { Trator+ } \\
\text { Recollhedor }\end{array}$ & $\begin{array}{l}\text { TL70 } \\
\text { Freeman } \\
\text { C7000 }\end{array}$ & 72 & 3,6 pilhas $\mathrm{h}^{-1}$ & 17,0 \\
\hline $\begin{array}{l}\text { Carregamento } \\
\text { das pilhas }\end{array}$ & Pá-carregadora & $\begin{array}{l}\text { Michigan } \\
55-C\end{array}$ & 47 & 14 pilhas. $h^{-1}$ & 3,9 \\
\hline Transporte & $\begin{array}{l}\text { Trator+ } \\
\text { Carretas }\end{array}$ & $\begin{array}{l}\text { MF292 } \\
\text { Capac. } \\
3 \text { pilhas }\end{array}$ & 90 & 12 pilhas. $\mathrm{h}^{-1}$ & 2,5 \\
\hline $\begin{array}{l}\text { Descarregamento } \\
\text { das pilhas }\end{array}$ & Pá-carregadora & $\begin{array}{l}\text { Michigan } \\
55-C\end{array}$ & 90 & 48 pilhas. $h^{-1}$ & 1,0 \\
\hline
\end{tabular}

*Obs: Uma pilha equivale a 67 fardos.

Os dados que primeiramente chamam a atenção na Tabela 02 são a baixa capacidade operacional efetiva do sistema, atribuída a menor largura de trabalho obtida pela excessiva sobreposição nas passadas e pela menor velocidade de operação, devido à presença de curvas de nível e rastros de pivô. A baixa eficiência dos equipamentos que, na maioria das sub-operações, 
é inferior a $80 \%$, também pode ser considerada crítica, pois contribuirá significativamente para a elevação dos custos da mecanização.

Pela análise da Tabela 02, também constata-se que as sub-operações mais onerosas ao sistema são a sega, utilizando-se tanto a segadora Case 8850 como a segadora Case 8312, e o enfardamento, com a enfardadora Freeman 270, superando os trinta reais por hectare de custo, como mostra a Figura 07 , onde os custos horários de cada sub-operação estão classificados em ordem decrescente.

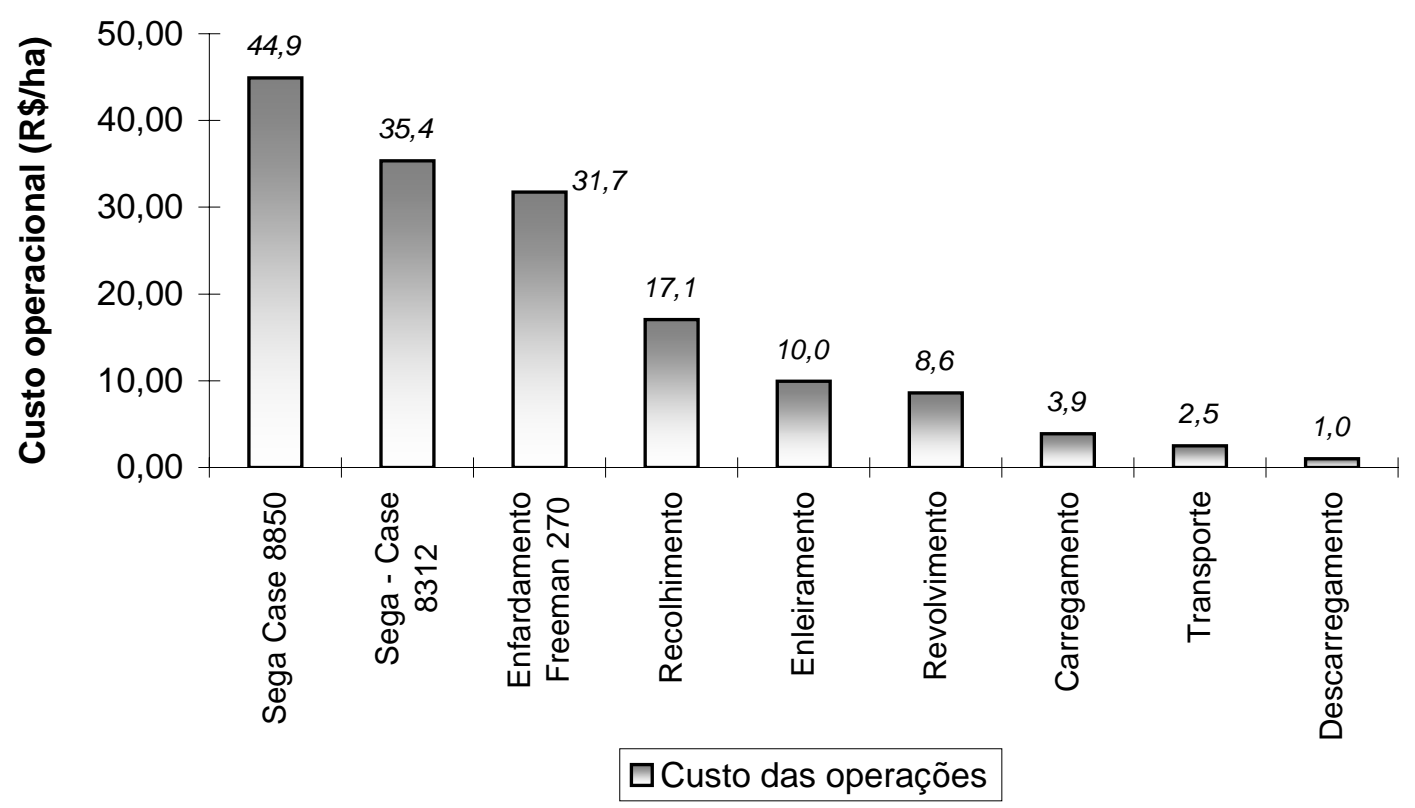

Figura 7 - Gráfico dos custos operacionais dos equipamentos para as suboperações de fenação, de acordo com as condições atuais do sistema mecanizado 


\subsubsection{Avaliação da qualidade das operações mecanizadas de fenação}

As operações avaliadas sob o ponto de vista de controle da qualidade foram selecionadas tendo como critérios a influência na qualidade final do feno. Com base neste critério, o processo de produção foi analisado e identificaramse como críticas as operações de sega e enfardamento, para as quais foram definidos os limites de especificação, referentes aos indicadores das operações.

Para a sega, estipulou-se o intervalo de 4 a $6 \mathrm{~cm}$ para a altura de corte, a fim de se garantir uma boa rebrota e evitar a contaminação da massa ceifada por resíduos de cortes anteriores ou terra, quando se tem um corte excessivamente baixo, ou evitar a formação de uma forragem com talos mais grossos e excessivos, quando se tem um corte alto. Para a operação de enfardamento, os indicadores selecionados têm o intuito de padronizar o tamanho dos fardos, facilitando-se as operações de recolhimento e estocagem, e melhorar a eficiência da operação, através do controle do número de ciclos de prensagem da enfardadora. O número de quatorze ciclos por fardo é recomendado como o ideal, pelo fabricante do equipamento, para que se produzam fardos bem compactados e de boa conformação. Os indicadores e itens de controle recomendados pelo corpo técnico da empresa, bem como seus limites de especificação, são apresentados na Tabela 03.

Tabela 3. Indicadores e limites de especificação utilizados para as operações de sega e enfardamento

\begin{tabular}{lllcc}
\hline \multirow{2}{*}{ Operações } & Indicadores & Especificação & \multicolumn{2}{c}{ Limites de Especificação } \\
\cline { 3 - 5 } Sega & $\begin{array}{l}\text { Altura de Corte } \\
(\mathrm{cm})\end{array}$ & $\begin{array}{l}\text { Altura da forrageira } \\
\text { após o corte }\end{array}$ & 4,0 & $\begin{array}{c}\text { Limite superior } \\
\text { (LSE) }\end{array}$ \\
Enfardamento & $\begin{array}{l}\mathrm{N}^{0} \text { de ciclos de } \\
\text { prensagem }\end{array}$ & $\begin{array}{l}\mathrm{N}^{0} \text { de ciclos da prensa } \\
\text { por fardo }\end{array}$ & 12 & 16 \\
Enfardamento & Comprimento(m) & Comprimento do fardo & 1,18 & 1,22 \\
\hline
\end{tabular}




\subsection{Avaliação da qualidade das operações críticas}

\subsubsection{Avaliação da qualidade da operação de sega}

Na Figura 08, são apresentados os gráficos de controle para os resultados média de altura de corte $(A)$ e da amplitude $(B)$ referentes à segadora de arrasto, Khun GMD 300. Verifica-se que a altura de corte média encontrada foi de $6,9 \mathrm{~cm}$ e, portanto, acima do limite superior de especificação. A operação não se encontra sob controle, segundo os critérios descritos por Vieira (1999), pois existem causas especiais atuando no processo. Para a média, de um total de trinta e um pontos, os quais variaram entre 4,5 e $8,5 \mathrm{~cm}$, oito estão fora dos limites de controle estatísticos e para a amplitude dois estão fora do controle indicando que a variação dentro dessas duas amostras não foi apenas causal. Segundo Jacovine (2000) o controle de um processo é realizado paulatinamente e que ao analisá-lo pela primeira vez, como é o caso deste trabalho, obter muitos pontos fora dos limites é comum. O autor observou esse fato ao avaliar a qualidade dos processos na colheita florestal referentes a: altura e faixa de fraturas das cepas; cepas danificadas, com espeto, cobertas e rachadas; comprimento das toras; toras com gancho. 

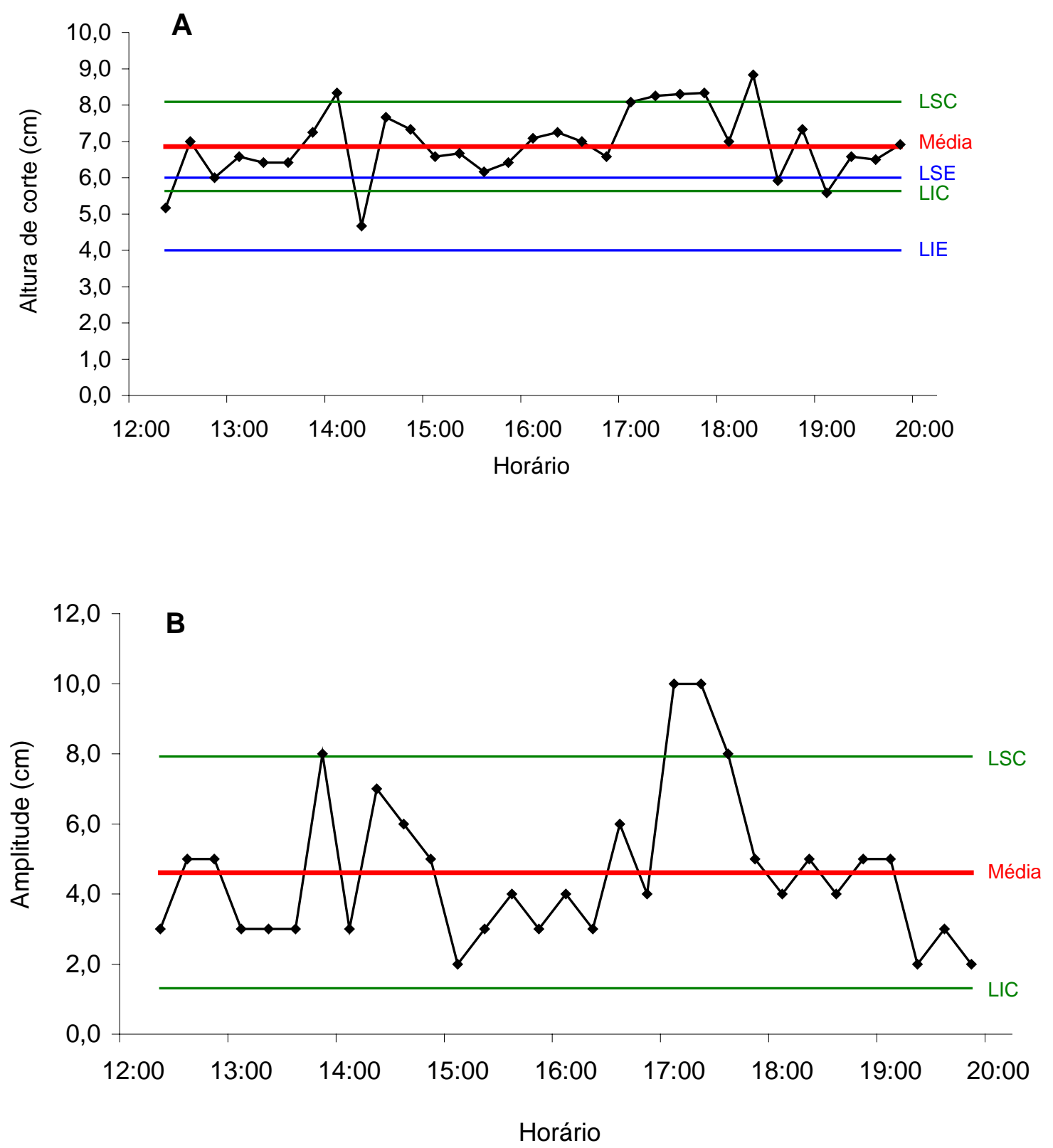

Figura 8 - (A) Gráfico de controle para a média e amplitude de altura de corte da segadora Khun GMD 300; (B) Gráfico de controle da amplitude; (LSC: Limite Superior de Controle; LIC: Limite Inferior de Controle; LSE: Limite Superior de Especificação; LIE: Limite Inferior de Especificação) 
Na Figura 09 é apresentada a distribuição da altura de corte para a segadora Khun. Apenas $45 \%$ dos pontos amostrados encontram-se dentro dos limites de especificação, menos de $1 \%$ estão abaixo do LIE e quase $54 \%$ dos pontos estão acima do LSE. A amplitude da altura de corte variou de 0 a $13 \mathrm{~cm}$ e a maior ocorrência, com $28 \%$ do total de pontos, foi à altura de $6 \mathrm{~cm}$, enquanto que a recomendação da operação era que a mesma fosse realizada entre 4 e $6 \mathrm{~cm}$, evidenciando o corte realizado acima do limite superior especificado pelos técnicos.

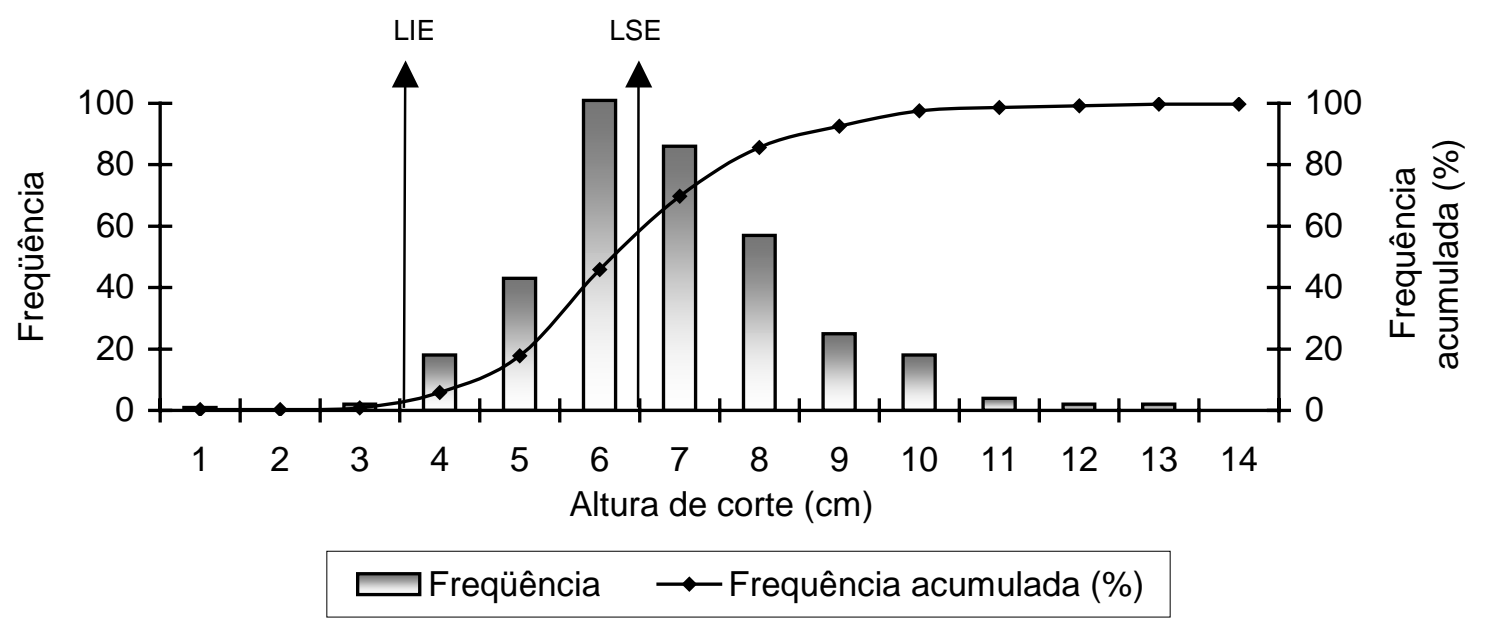

Figura 9 - Histograma da distribuição da altura de corte da segadora Khun GMD300

De modo análogo, para a segadora autopropelida Case 8850, o processo não se encontra sob controle evidenciando a existência de causas especiais. Para a altura, a média de corte foi de $6,4 \mathrm{~cm}$ e do total de trinta e quatro pontos, cinco se apresentam fora dos limites de controle. É interessante observar que nenhum ponto está abaixo do limite inferior de especificação, Figura 10 (A e B). A variação dos pontos está entre 5 e $8,5 \mathrm{~cm}$, sendo menor do que a obtida com a segadora Khun. 

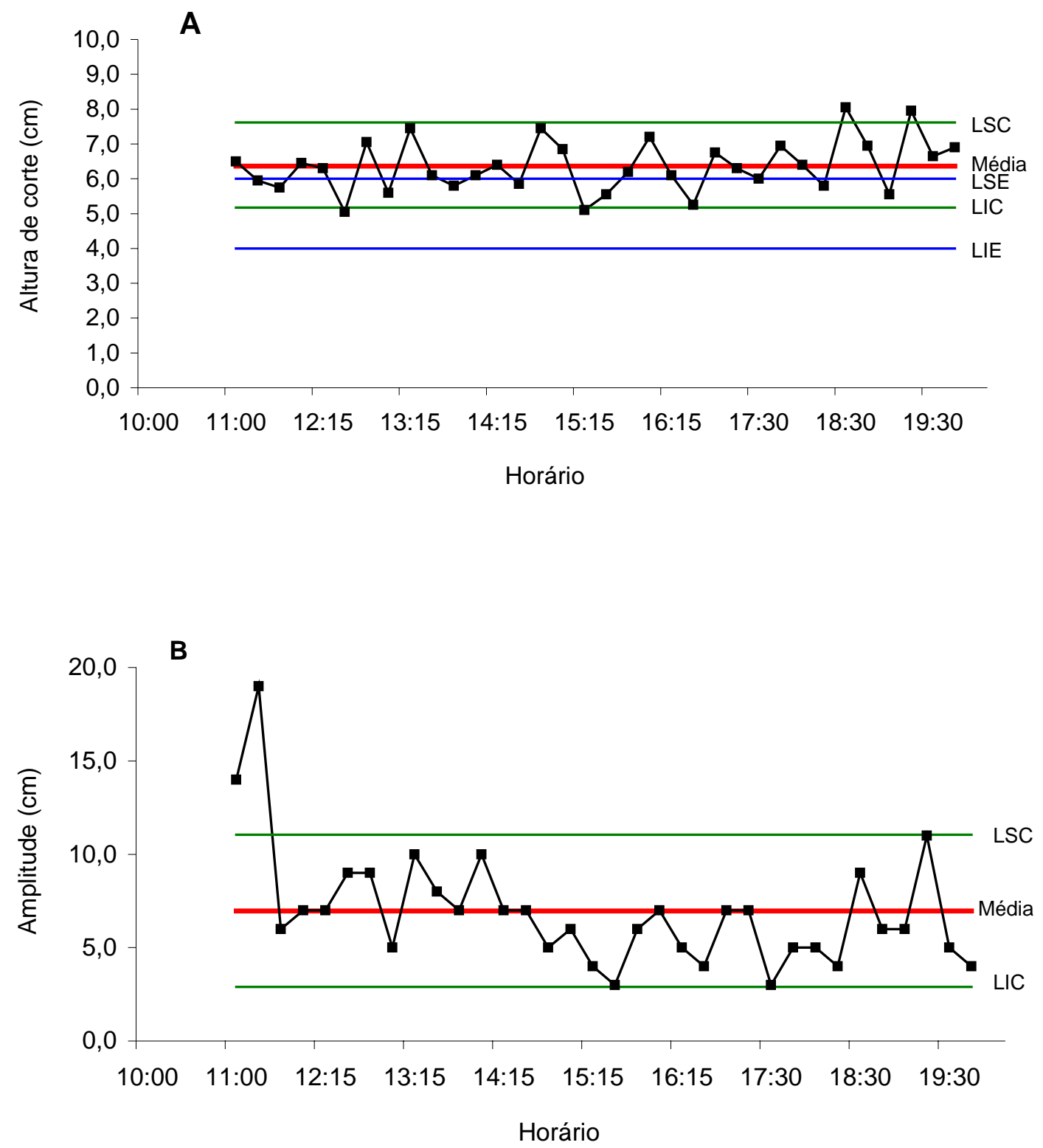

Figura 10 - Gráfico de controle para a média e amplitude de altura de corte da segadora Case 8850; (LSC: Limite Superior de Controle; LIC: Limite Inferior de Controle; LSE: Limite Superior de Especificação; LIE: Limite Inferior de Especificação) 
$\mathrm{Na}$ operação de corte com a segadora Case 8850, 53 \% dos pontos amostrados estão entre os limites de especificação, 4\% estão abaixo do LIE e $43 \%$ acima do LSE, Figura 11. A amplitude de distribuição da altura de corte variou entre 0 e $19 \mathrm{~cm}$, com maior ocorrência de pontos entre 5 e $6 \mathrm{~cm}$, somando ao redor de $40 \%$ do total. Em comparação à segadora Khun, há uma maior variação entre as alturas de corte, porém maior concentração de pontos entre as alturas estipuladas dentro do padrão desejado.

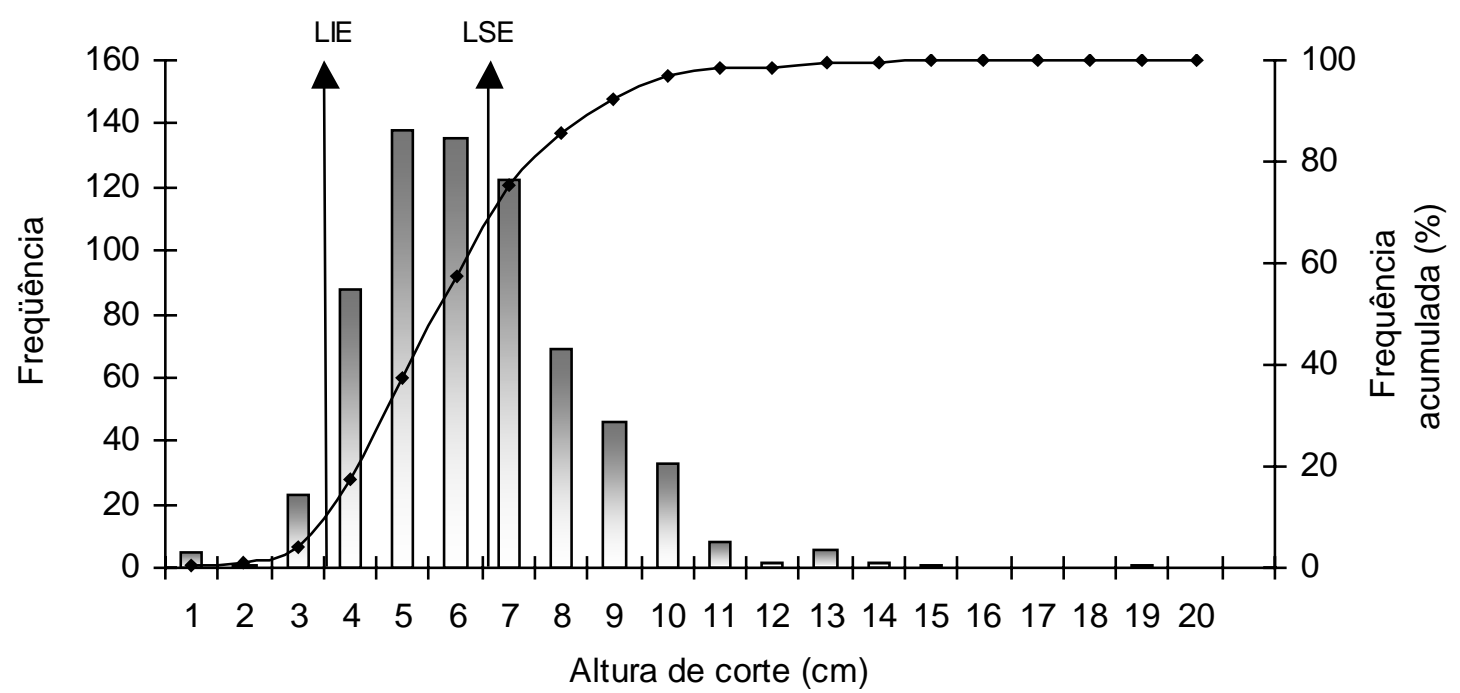

$\square$ Freqüência $\multimap-$ Frequência acumulada (\%)

Figura 11 - Histograma da distribuição da altura de corte da segadora CASE 8850

Como considerações gerais sobre a operação de sega, tem-se primeiramente que os resultados tanto para a segadora Khun, como para a Case, indicam que existem causas especiais atuando no processo que podem estar relacionadas com as irregularidades do terreno, presença de curvas de nível ou os rastros dos pivôs, o que prejudica o desempenho operacional do processo e também a qualidade da operação.

A média da altura de corte entre as duas segadoras também deve ser considerada, de modo que a segadora Case possui uma média de corte de 6,4 
$\mathrm{cm}$, ou seja, 0,5 cm menor do que a média da Khun, a qual ficou em 6,9 cm. Em relação à altura média de corte especificada pelo corpo técnico, $5 \mathrm{~cm}$, a regulagem do equipamento de sega foi elevada de $1,4 \mathrm{~cm}$ para a segadora Case e 1,9 cm para a Khun.

A ausência de pontos médios nos gráficos de controle abaixo do limite inferior de especificação, padronizado em $4 \mathrm{~cm}$, pode ser explicada, em função das irregularidades do terreno. Com a finalidade de se evitar injúrias às plantas em um corte muito próximo ao solo ou se produzir uma massa ceifada com muitas impurezas minerais e com material de cortes anteriores, o operador procura trabalhar com a plataforma mais elevada, mesmo que isso tenha como conseqüências o corte fora do limite especificado.

Por fim, a segadora Case apresenta melhor distribuição de pontos dentro dos limites de especificação, o que pode ser explicado pelo maior número de regulagens e pela plataforma flutuante presentes nesta máquina.

\subsubsection{Avaliação da qualidade da operação de enfardamento}

- Contagem manual dos ciclos de prensagem;

Para a operação de enfardamento, foram determinados dois indicadores: número de ciclos da prensa por fardo e o comprimento dos fardos. Na Figura 12 são apresentados os gráficos de controle para a média (A) e amplitude (B) referentes ao número de ciclos da prensa por fardo. Verifica-se que o processo não se encontra sob controle, pois existem pontos fora dos limites, tanto para a média como para a amplitude. As causas especiais podem estar relacionadas com a velocidade da operação e à distribuição da massa na área, a qual influencia o tamanho das leiras por ocasião da operação de enleiramento. A operação não tem a qualidade requerida, número de ciclos, pois vários pontos médios estão entre o limite inferior de controle (LIC) e o limite inferior de especificação (LIE), e a média obtida está abaixo do LIE. 


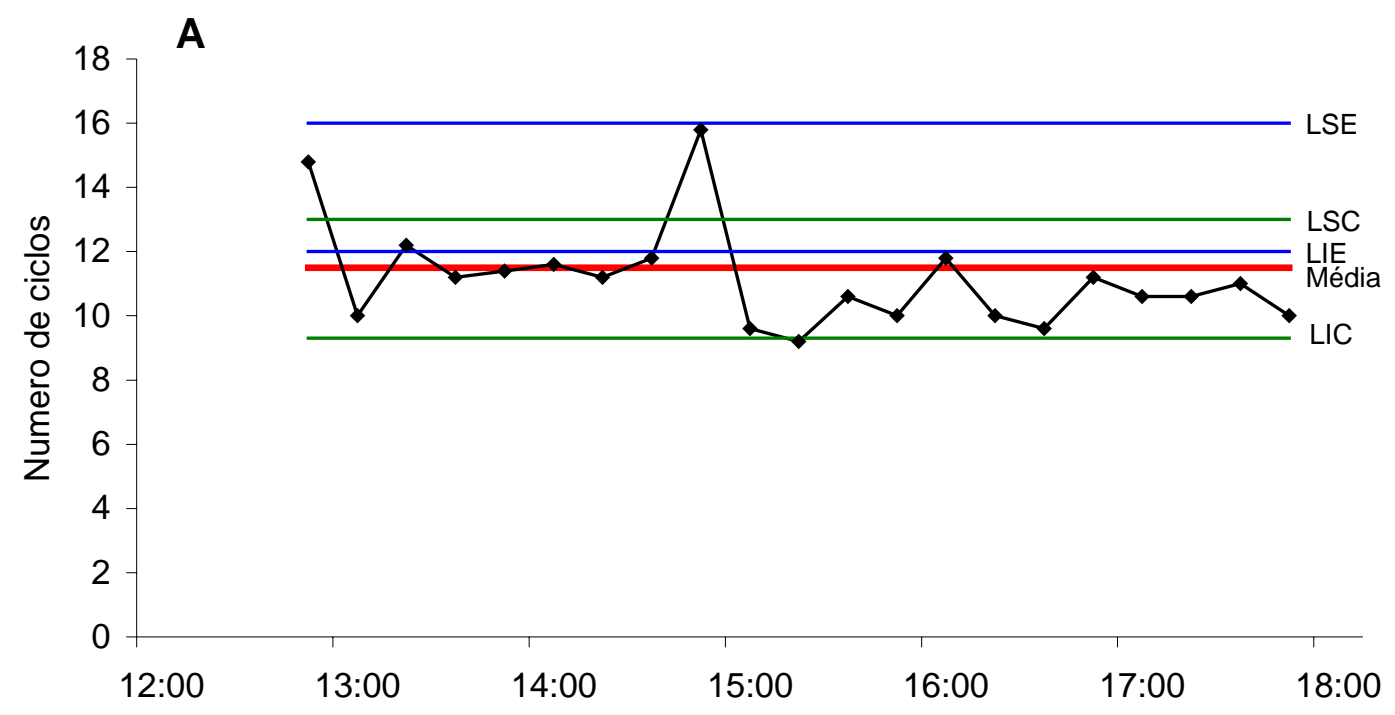

Horário

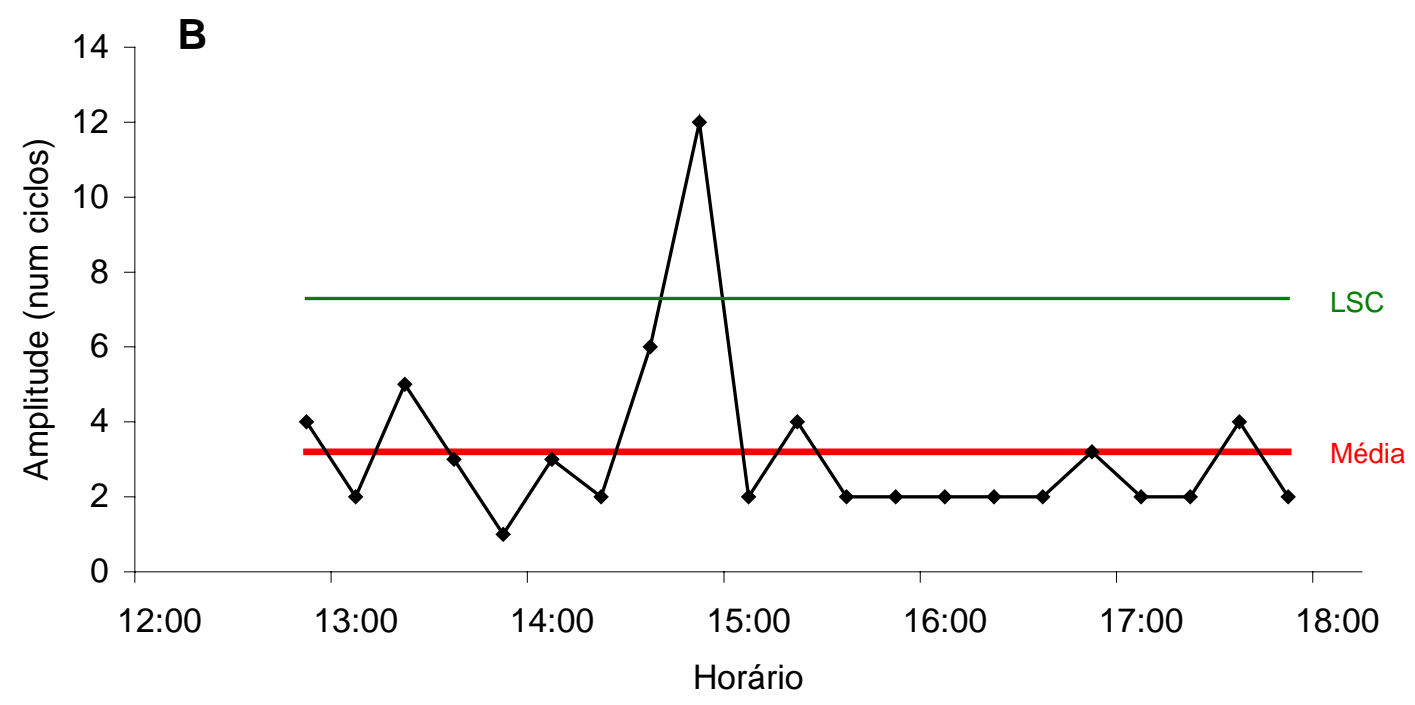

Figura 12 - Gráfico de controle para a média e amplitude do no de ciclos da prensa da enfardadora por fardo; (LSC: Limite Superior de Controle; LIC: Limite Inferior de Controle; LSE: Limite Superior de Especificação; LIE: Limite Inferior de Especificação) 
Conforme a Figura 12, existe uma alteração do comportamento da variação dos pontos à partir das 15 horas, quando a distribuição passou a ficar abaixo da média. Neste caso, houve mudança na condição de operação por parte do operador, o qual foi instruído a trabalhar mais rápido após as 15 horas, devido ao atraso no cumprimento dos prazos. Como conseqüência, diminuiu-se o número de ciclos da prensa por fardo, ocorrendo uma mudança no nível da característica da qualidade.

A distribuição do número de ciclos da prensa da enfardadora por fardo, apresenta maior concentração de pontos em 10 ciclos, cerca de $35 \%$ e, apenas $28 \%$ dos pontos encontram-se dentro da faixa de especificação, Figura 13, evidenciando a regulagem inadequada do equipamento para atender ao especificado pelo corpo técnico.

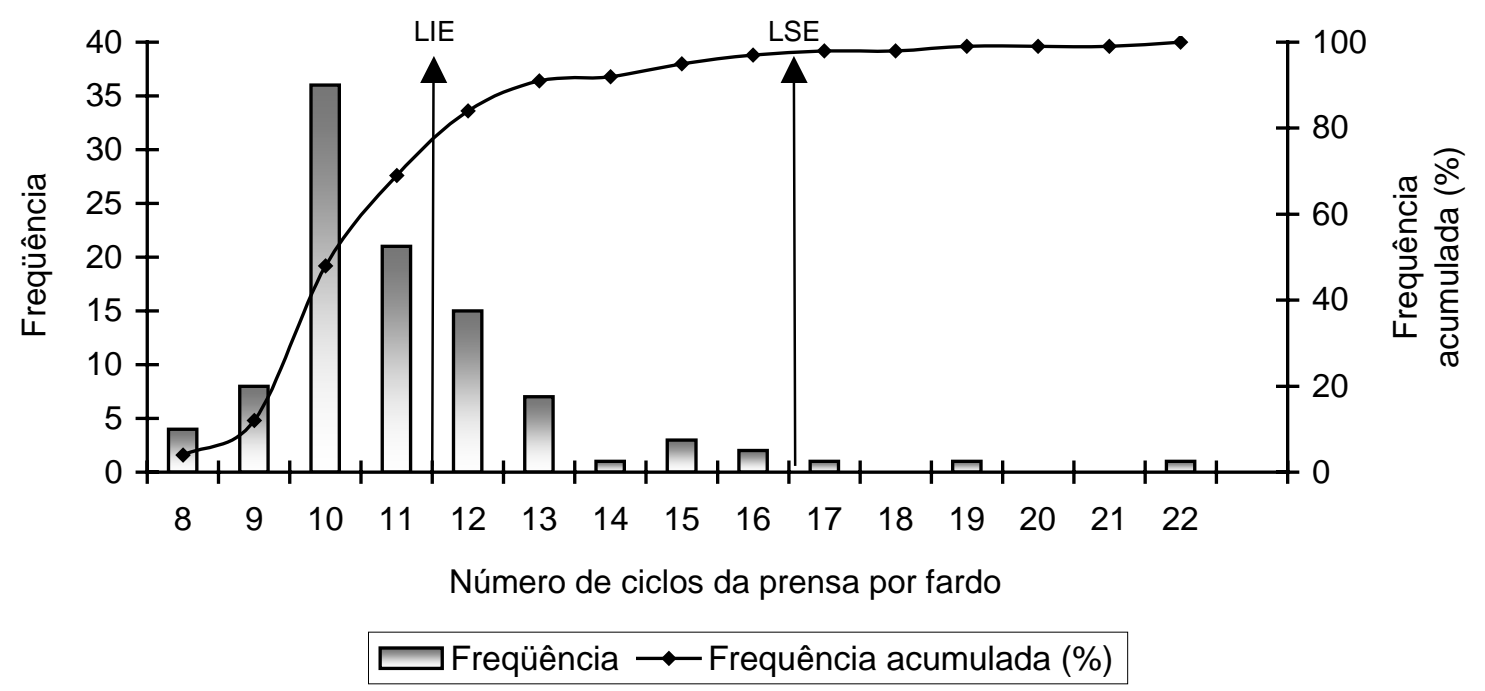

Figura 13 - Histograma da distribuição do número de ciclos da prensa da enfardadora por fardo

O segundo indicador avaliado para a operação de enfardamento foi 0 comprimento dos fardos, o qual exerce influência sob as operações de recolhimento e armazenamento. A Figura 14 apresenta o gráfico de controle para a média (A) e amplitude (B) do comprimento dos fardos. 

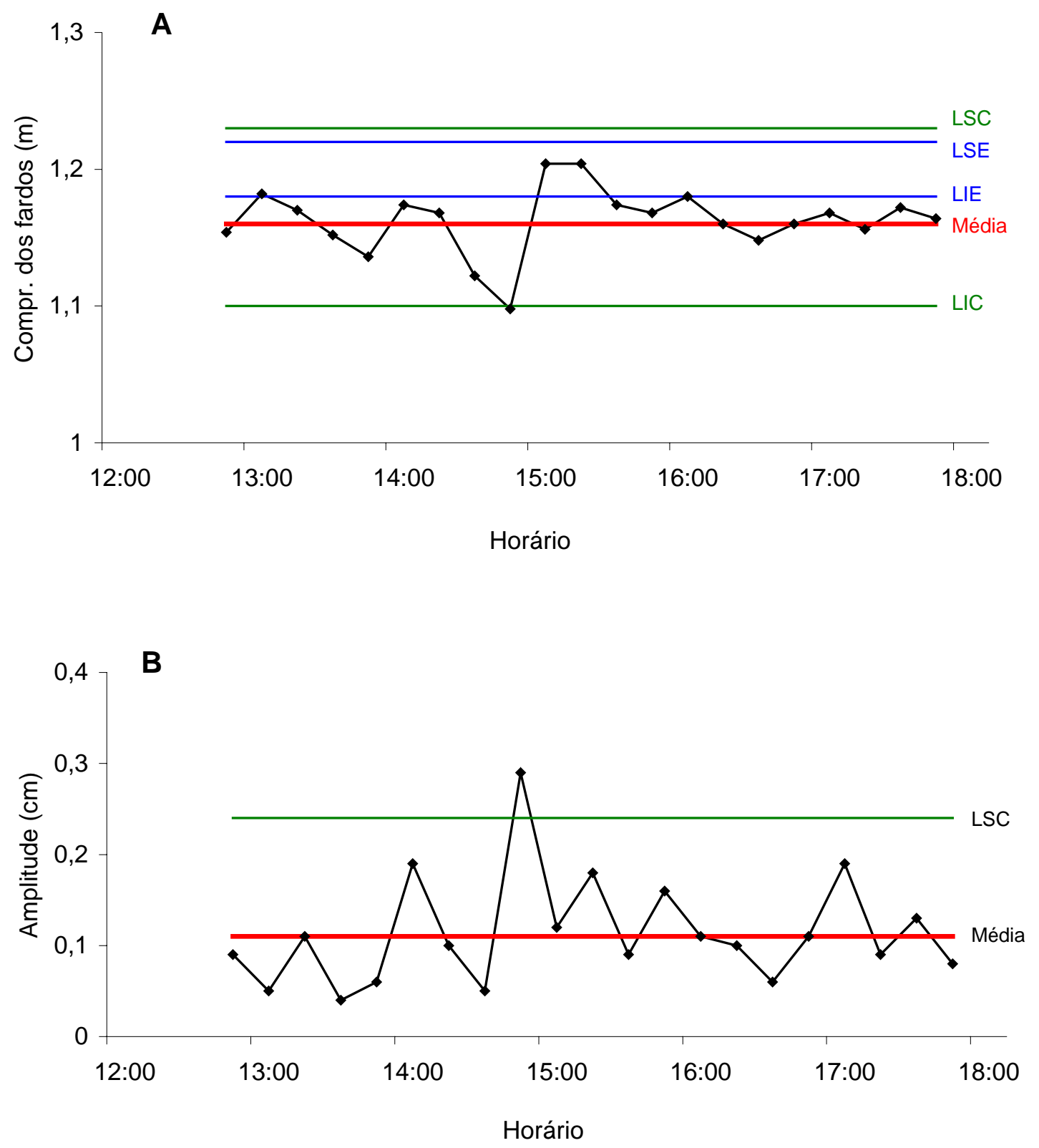

Figura 14 - Gráfico de controle para a média e amplitude do comprimento dos fardos; (LSC:Limite Superior de Controle; LIC:Limite Inferior de Controle; LSE: Limite Superior de Especificação; LIE: Limite Inferior de Especificação) 
O tamanho ideal do fardo deve ser de 1,2 metros $(1,18$ a $1,22 \mathrm{~m})$ para que o equipamento recolhedor possa formar adequadamente as pilhas, executando o seu travamento eficientemente e evitando o seu tombamento durante o armazenamento. Assim, a avaliação da Figura 14, a qual apresenta o gráfico de controle para a média (A) e amplitude (B), pode ser observado que somente em uma amostra referente à amplitude, a variação dos dados não foi apenas causal. Ressalta-se aqui a alteração na operação após as 15 horas, decorrente do aumento de velocidade solicitado ao operador e como conseqüência ocorreu a diminuição do número de ciclos da prensa e aumento do comprimento dos fardos. A média de comprimento obtido para os fardos foi 1,16 metros e a maioria dos pontos encontra-se abaixo do limite inferior de especificação (LIE) não atendendo às necessidades da empresa.

A Figura 15 traz o histograma da distribuição do comprimento dos fardos, no qual constata-se a concentração de pontos em 1,16 m, com $12 \%$ do total. Apenas $27 \%$ dos fardos possuem comprimento dentro da faixa de especificação e conseqüentemente $63 \%$ dos fardos estão fora do padrão desejado.

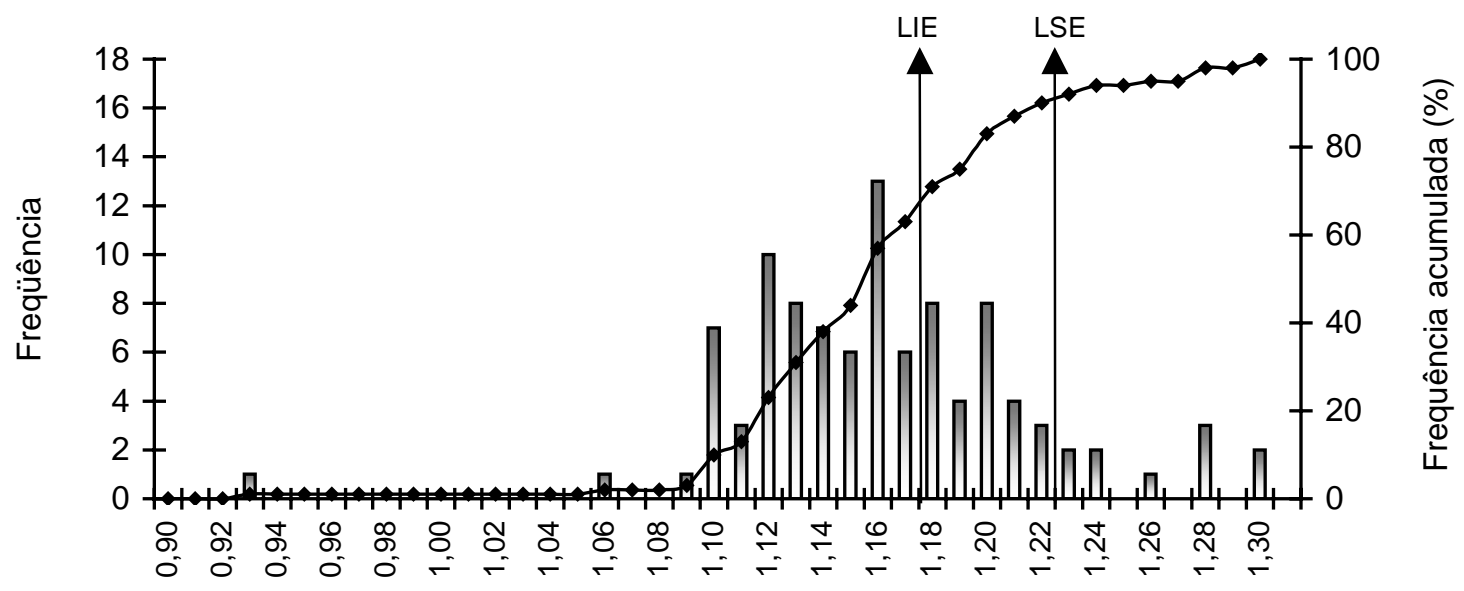

Comprimento dos fardos $(\mathrm{m})$

$\square$ Freqüência $\multimap$ • Frequência acumulada (\%)

Figura 15 - Histograma da distribuição do comprimento dos fardos 
Com isso pode-se considerar que o indicador de qualidade, comprimento dos fardos, está sob controle estatístico, porém encontra-se abaixo dos valores pretendidos pela empresa, comprometendo as operações subseqüentes de recolhimento e armazenamento.

Como primeira consideração geral sobre a operação de enfardamento, tem-se que dos dois indicadores avaliados, o número de ciclos não está sob controle e também não atende aos requisitos da empresa. Por um outro lado, o comprimento dos fardos encontra-se sob controle estatístico, porém fora dos padrões especificados, tornando-se necessário a realização de um estudo das possíveis causas de influência no processo. O treinamento dos operadores pode garantir a melhoria da qualidade técnica de operação dos equipamentos, aproximando a execução das atividades mecanizadas aos limites estabelecidos.

Desta forma, o desenvolvimento de um dispositivo que registre o número de ciclos da prensa da enfardadora por fardo, pode garantir a adequada manutenção do indicador. Conforme pode ser observado na Figura 16, existe uma alta correlação $\left(R^{2}=0,8862\right)$ entre o número de ciclos e o comprimento do fardo, de forma que o dispositivo pode colaborar para a manutenção da medida especificada.

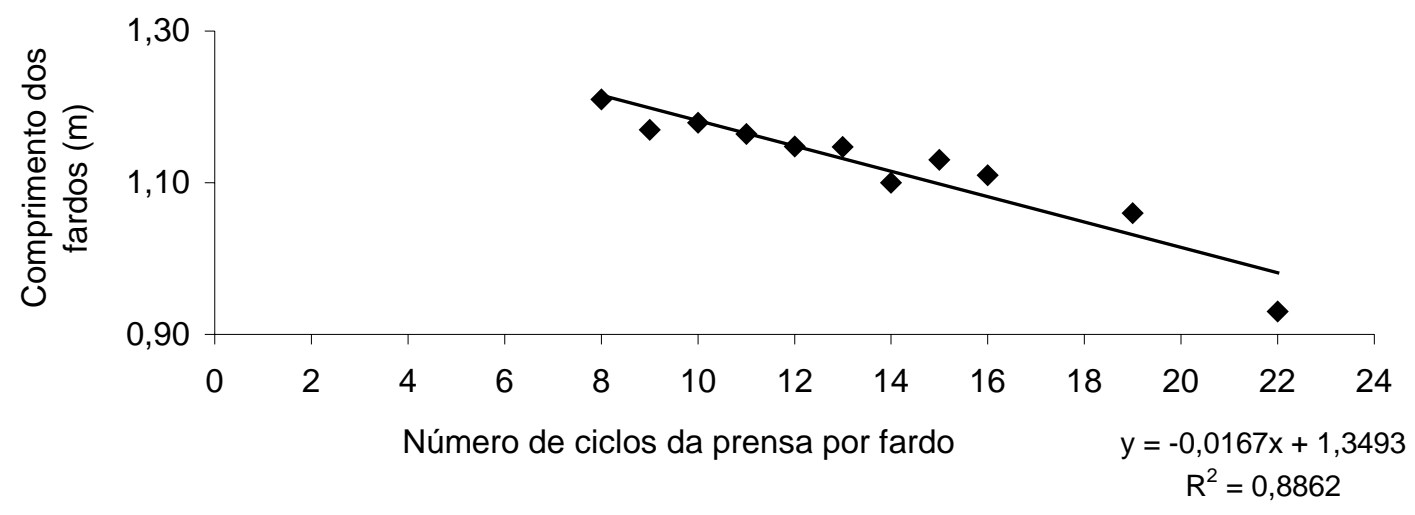

Figura 16 - Gráfico de correlação entre número de batidas da prensa da enfardadora e comprimento dos fardos 
O aumento no número de ciclos da prensa causa uma diminuição no comprimento do fardo. Com o procedimento atual, para se obter o fardo entre 1,18 a 1,22 m, o número de ciclos teórico está situado no intervalo de 8 a 10 . Este menor número em relação ao recomendado, pode ser justificado pela maior regulagem de compressão dos barbantes do sistema de amarração da enfardadora. Sabendo-se que o operador trabalha com um menor número de ciclos e que, por conseqüência, o comprimento será maior que o desejado, aumenta-se a compressão dos barbantes para não deixar o fardo sem pressão.

Portanto, a operação de enfardamento apresenta um grande potencial de melhoria, e para tanto exige que um dispositivo de contagem seja montado no equipamento. A correlação entre o número de ciclos e o tamanho do fardo é significativa, atendendo diretamente a uma característica do produto final.

- Desenvolvimento e introdução de sistema eletrônico de contagem dos ciclos de prensagem;

A Figura 17 traz os gráficos de controle para a média (A) e amplitude (B) referentes ao número de ciclos da prensa por fardo, com a utilização do sistema eletrônico de contagem dos ciclos da prensa por fardo, porém somente visualizado pelo apontador de campo, ou seja, sem o controle da operação por parte do operador. Verifica-se que o processo não se encontra sob controle, pois existem pontos fora dos limites, tanto para a média como para a amplitude, o que indica que causas especiais estão atuando no processo.

As causas especiais podem estar relacionadas com a velocidade da operação e à elevada produtividade do talhão $\left(6,5\right.$ t.ha $\left.{ }^{-1}\right)$. A operação não tem a qualidade requerida, número de ciclos, pois grande parte dos pontos médios encontra-se acima do limite superior de especificação (LSE). 

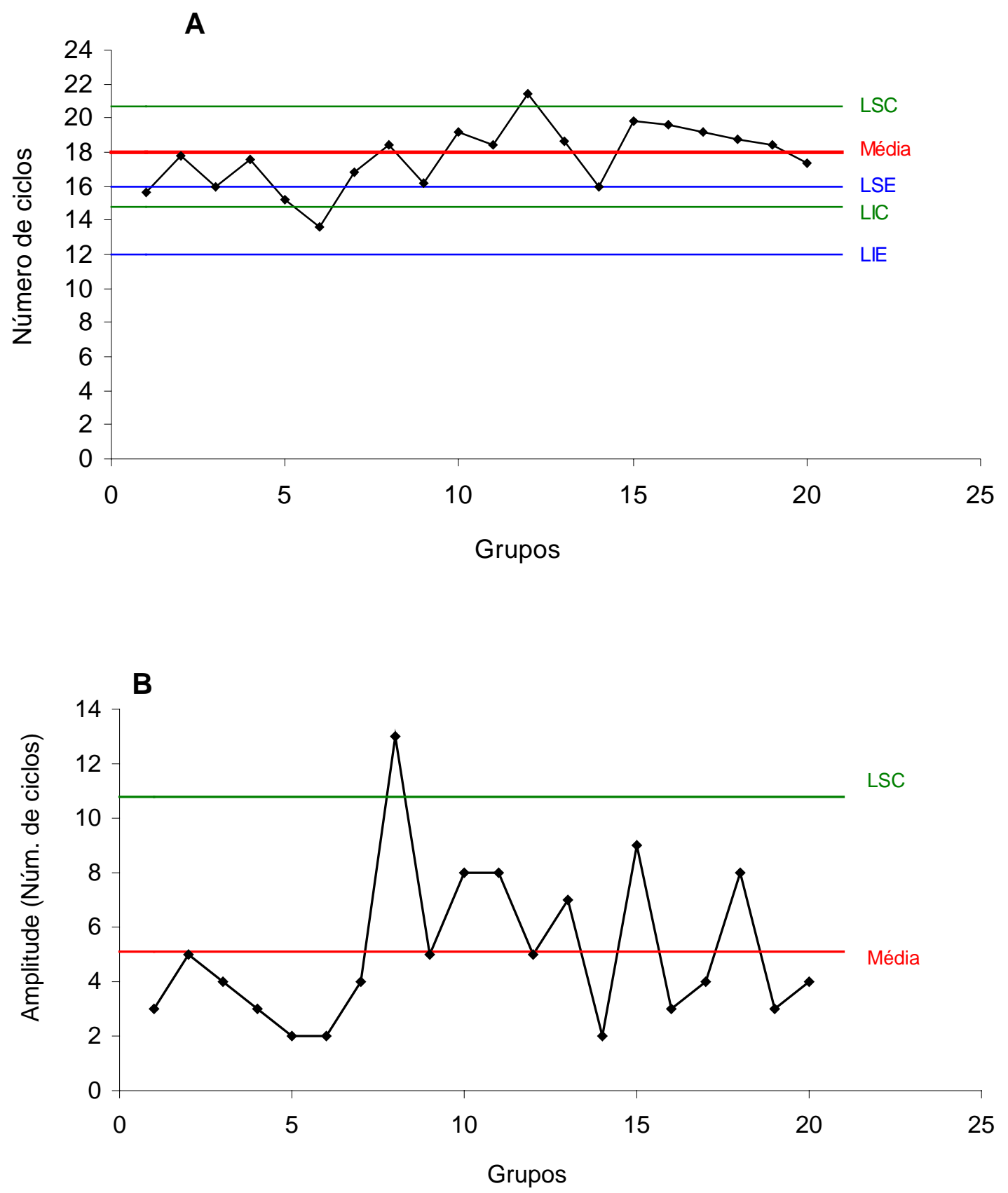

Figura 17 - Gráfico de controle para a média e amplitude do $\mathrm{n}^{\circ}$ de ciclos da prensa da enfardadora por fardo, sem o controle eletrônico de contagem; (LSC: Limite Superior de Controle; LIC: Limite Inferior de Controle; LSE: Limite Superior de Especificação; LIE: Limite Inferior de Especificação) 
A análise Figura 17 (A) evidencia que pelo fato da maioria dos pontos encontrarem-se acima do limite superior de especificação, a média dos pontos é de 18 ciclos da prensa por fardo, acima do ideal de operação recomendado pelo fabricante, bem como da faixa de operação pretendida pela empresa. Neste caso específico, o operador estava trabalhando sem o auxílio do sistema eletrônico de contagem, o que acarreta em um tempo maior de adequação da velocidade de deslocamento às diferenças na quantidade de massa na leira. Pode-se visualizar também na Figura 17 (B), a grande amplitude do gráfico, a qual varia entre 2 e 13 ciclos e, portanto, o processo não obedece à uma rotina.

A Figura 18 apresenta o histograma da distribuição do número de ciclos de prensagem por fardo sem o controle da operação pelo operador, no qual observa-se que apenas 39\% dos fardos foram formados dentro dos limites especificados pela propriedade, de forma que $61 \%$ ficaram acima do desejado. Nota-se inclusive a grande dispersão dos resultados, confirmando que o processo realmente não segue uma rotina de trabalho.

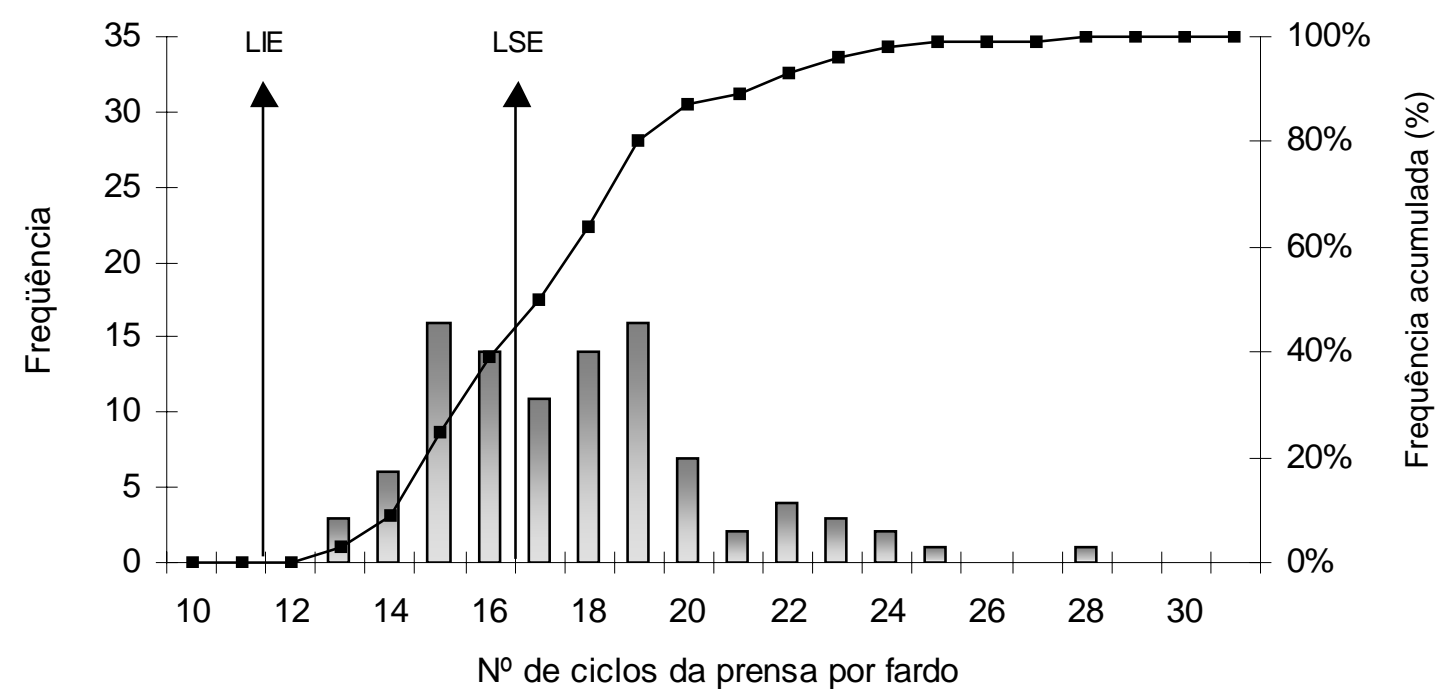

$\square$ Freqüência $\rightarrow$ \% cumulativo

Figura 18 - Histograma da distribuição do número de ciclos da prensa da enfardadora por fardo, sem a utilização do sistema eletrônico de contagem 
Na Figura 19 são apresentados os gráficos de controle para a média (A) e amplitude (B) referentes ao número de ciclos da prensa por fardo, com a utilização do sistema eletrônico de contagem dos ciclos da prensa por fardo e controle da operação por parte do operador.
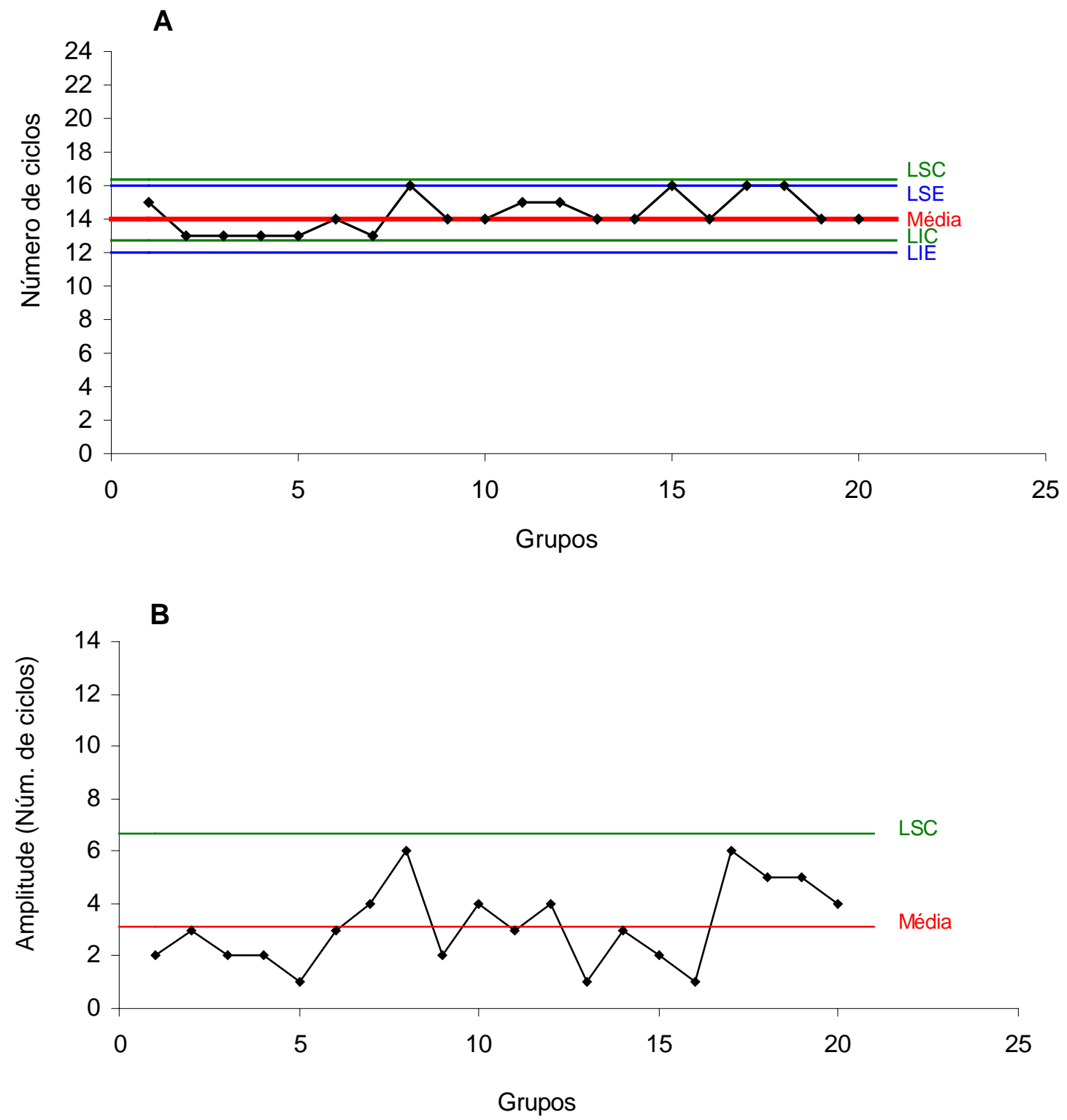

Figura 19 - Gráfico de controle para a média e amplitude do $\mathrm{n}^{\circ}$ de ciclos da prensa da enfardadora por fardo, com o controle eletrônico de contagem; (LSC: Limite Superior de Controle; LIC: Limite Inferior de Controle; LSE: Limite Superior de Especificação; LIE: Limite Inferior de Especificação) 
Na Figura 19 constata-se que o processo encontra-se sob controle, tanto sob o aspecto estatístico como de especificação, uma vez que não há pontos fora dos limites de controle e dos limites de especificação.

A utilização do sistema eletrônico de contagem dos ciclos da prensa por fardo resultou na diminuição da média para 14 ciclos por fardo. Tem-se também que a amplitude dos pontos ficou menor, variando entre 1 e 6 ciclos por fardo. Assim, pode-se afirmar que a operação foi melhorada com a introdução do sistema eletrônico, mantendo o processo controlado e próximo ao ideal.

Na Figura 20 tem-se o histograma da distribuição do número de ciclos de prensagem por fardo com o controle da operação pelo operador, através da utilização do dispositivo eletrônico de contagem, onde $81 \%$ dos resultados ficaram entre os limites estipulados, para o qual 32\% concentraram-se em 14 ciclos por fardo, ideal para a operação.

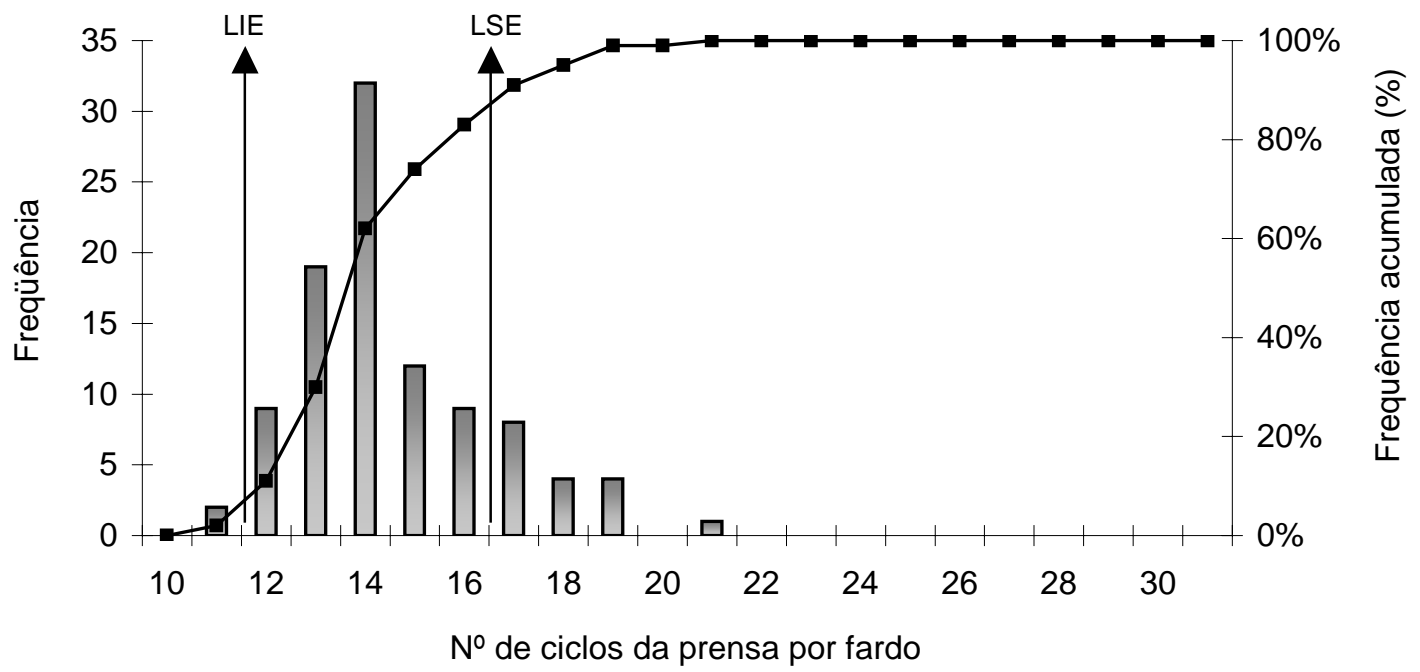

Figura 20 - Histograma da distribuição do número de ciclos da prensa da enfardadora por fardo, com a utilização do sistema eletrônico de contagem 
Portanto confirma-se a melhoria da operação pela inclusão do sistema eletrônico de contagem, o qual reduziu a média de ciclos por fardo e propiciou melhor regularidade ao processo.

O segundo indicador avaliado para a operação de enfardamento, utilizando-se o sistema eletrônico de contagem dos ciclos de prensagem da enfardadora, foi o comprimento dos fardos. O comprimento do fardo é uma característica de extrema importância ao processo de fenação e a manutenção de um comprimento regular, entre 1,18 e 1,22 metros é considerada ideal para a adequada realização das operações subseqüentes, recolhimento e armazenamento. A realização do enfardamento fora dos limites de comprimento prejudica a disposição dos fardos na formação das pilhas, desequilibrando sua estrutura e ocasionando seu tombamento, o qual gera retrabalho e custos adicionais ao sistema.

A Figura 21 traz os gráficos de controle para a média (A) e amplitude (B) referentes ao comprimento do fardo, sem a utilização do sistema eletrônico de contagem dos ciclos da prensa por fardo. Verifica-se que o processo encontrase fora de controle para a média, porém a variação da amplitude está dentro dos limites de controle, indicando que a variação das amostras não é puramente casual. Provavelmente as causas deste fato devem estar relacionadas à elevada produtividade do talhão $\left(6,5 \mathrm{t} \mathrm{de} \mathrm{ms}^{-} \mathrm{ha}^{-1}\right)$, bem como a eventuais falhas de regulagem da enfardadora.

Assim como constatado para o número de ciclos da prensa por fardo, a operação não tem a qualidade requerida e grande parte dos pontos médios encontra-se abaixo do limite inferior de especificação (LSE), sendo que a média do comprimento é de 1,17 m. 

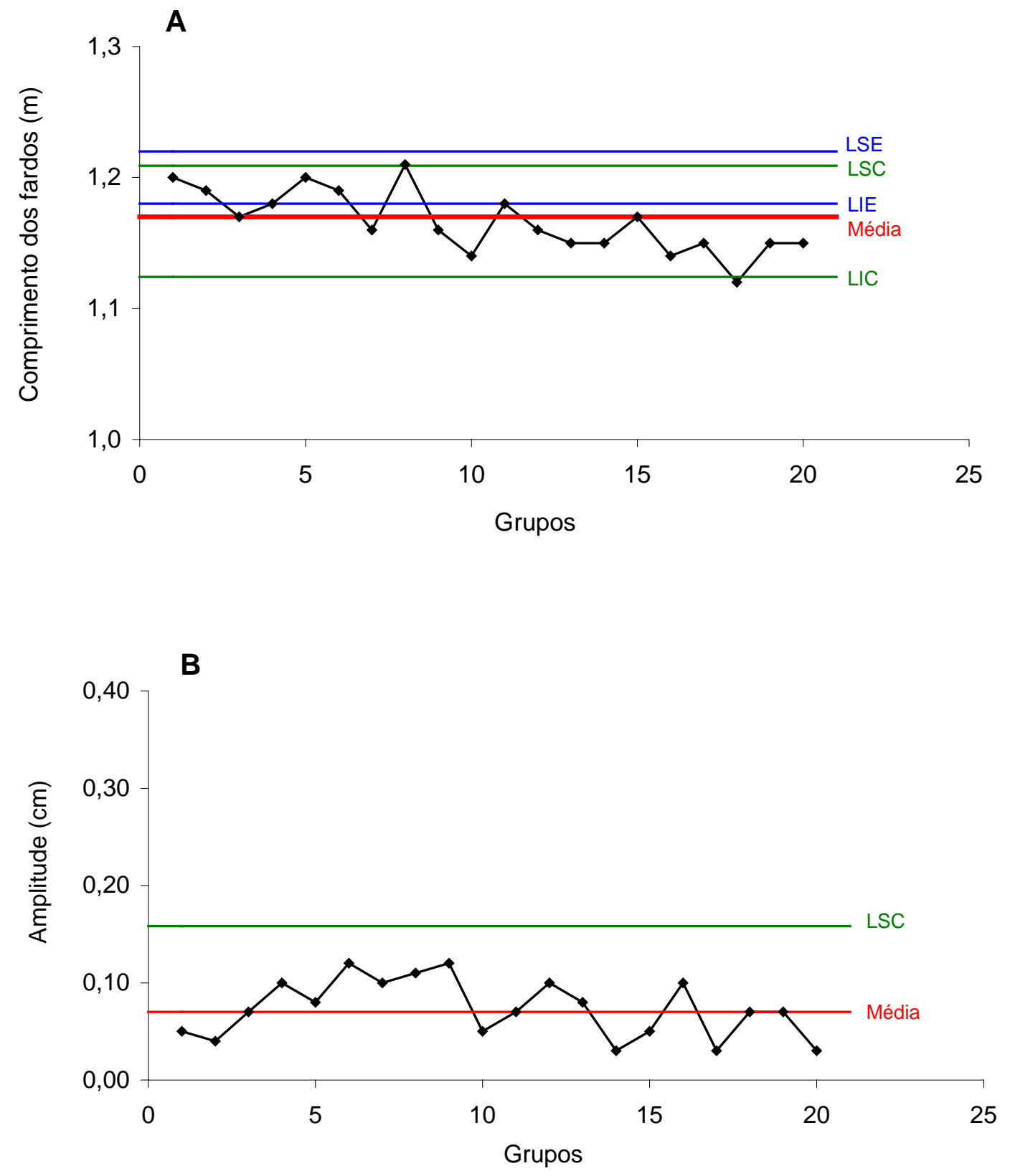

Figura 21 - Gráfico de controle para a média e amplitude do comprimento dos fardos, sem o controle eletrônico de contagem; (LSC: Limite Superior de Controle; LIC: Limite Inferior de Controle; LSE: Limite Superior de Especificação; LIE: Limite Inferior de Especificação) 
Desta forma, pela análise da Figura 21 (B) tem-se uma elevada amplitude do comprimento dos fardos, variando entre 3 e $12 \mathrm{~cm}$, o que indica que o processo não obedece à uma rotina.

A Figura 22 apresenta o histograma da distribuição do comprimento dos fardos sem o controle da operação pelo operador, onde pode-se ver a grande dispersão dos pontos, indicando a desuniformidade do comprimento dos fardos. Nota-se também que $62 \%$ dos fardos possuem comprimento inferior ao estipulado pela empresa e que apenas $32 \%$ encontram-se com comprimento adequado e somente $13 \%$ dos fardos possuem 1,20 m, considerado ideal.

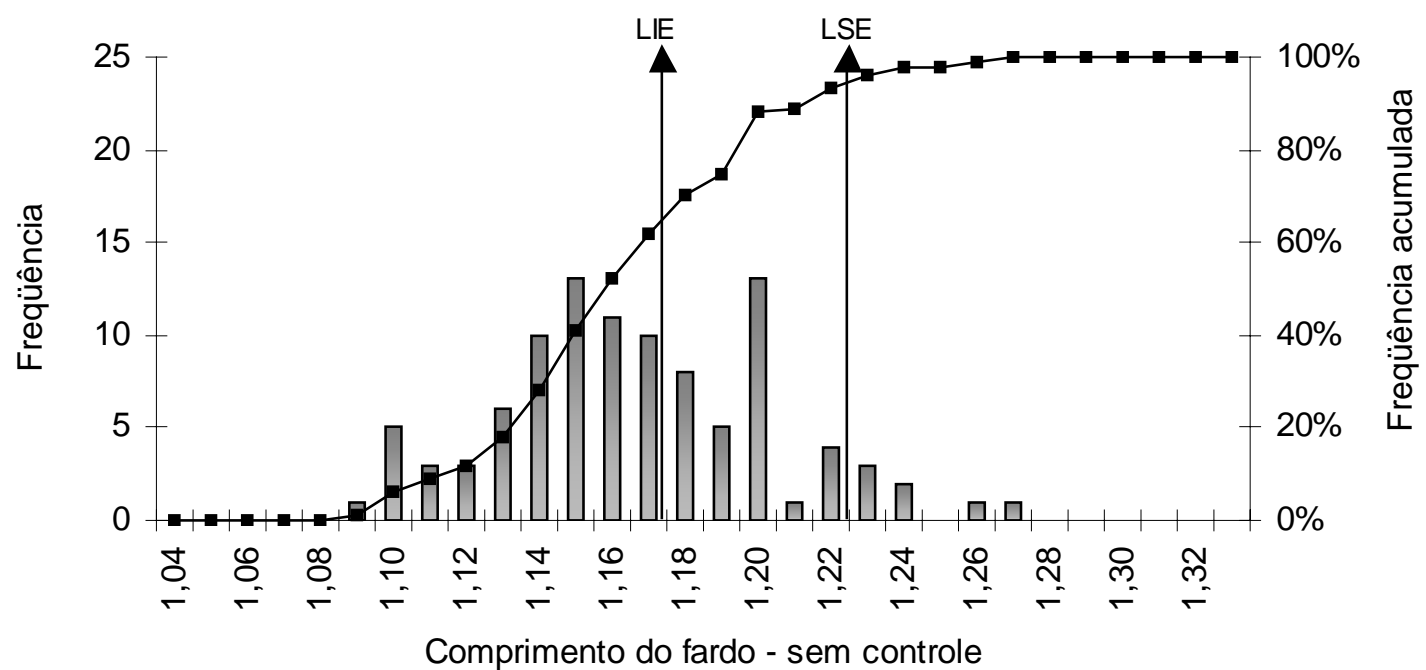

Freqüência $\rightarrow$ \% cumulativo

Figura 22 - Histograma da distribuição do comprimento interno do fardo, sem a utilização do sistema eletrônico de contagem

Na Figura 23 estão descritos os gráficos de controle para a média (A) e amplitude (B) referentes ao comprimento do fardo, com a utilização do sistema eletrônico de contagem dos ciclos da prensa por fardo. O processo está totalmente sob controle, uma vez que a média de comprimento dos fardos encontra-se dentro dos limites, tanto de controle como de especificação, bem como a variação da amplitude está dentro dos limites de controle. 

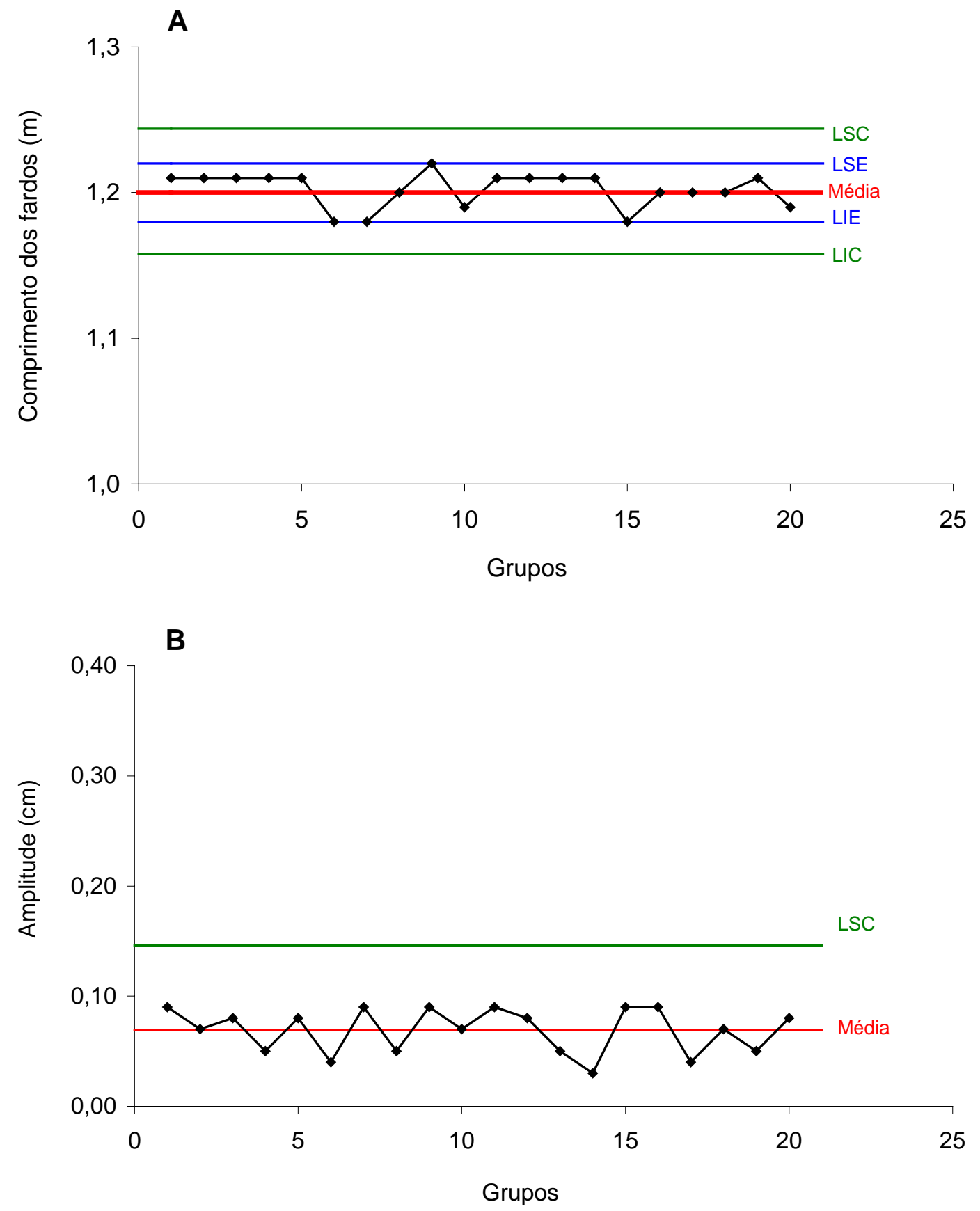

Figura 23 - Gráfico de controle para a média e amplitude do comprimento dos fardos, com o controle eletrônico de contagem; (LSC: Limite Superior de Controle; LIC: Limite Inferior de Controle; LSE: Limite Superior de Especificação; LIE: Limite Inferior de Especificação) 
$\mathrm{Na}$ análise da Figura 23, assim como constatado para o número de ciclos da prensa por fardo utilizando-se o sistema de contagem eletrônico do número de ciclos, a operação possui a qualidade requerida, obtendo-se uma média de comprimento por fardo de $1,20 \mathrm{~m}$, considerada ideal para a operação. Da mesma forma, a amplitude dos pontos ficou menor, variando entre 3 e $9 \mathrm{~cm}$ por fardo, atendendo também á qualidade exigida para a operação.

O histograma da Figura 24 representa os resultados para a execução da operação de enfardamento auxiliada pelo sistema eletrônico de contagem dos ciclos da prensa por fardo. Constata-se a maior uniformidade dos pontos, de forma que $66 \%$ dos fardos amostrados possuem comprimento dentro da faixa especificada e que $24 \%$ dos fardos amostrados possuíram comprimento de 1,20 metros, considerado ideal. Isto representa uma melhoria de $34 \%$ ao sistema, comparada à execução do enfardamento sem o auxílio eletrônico.

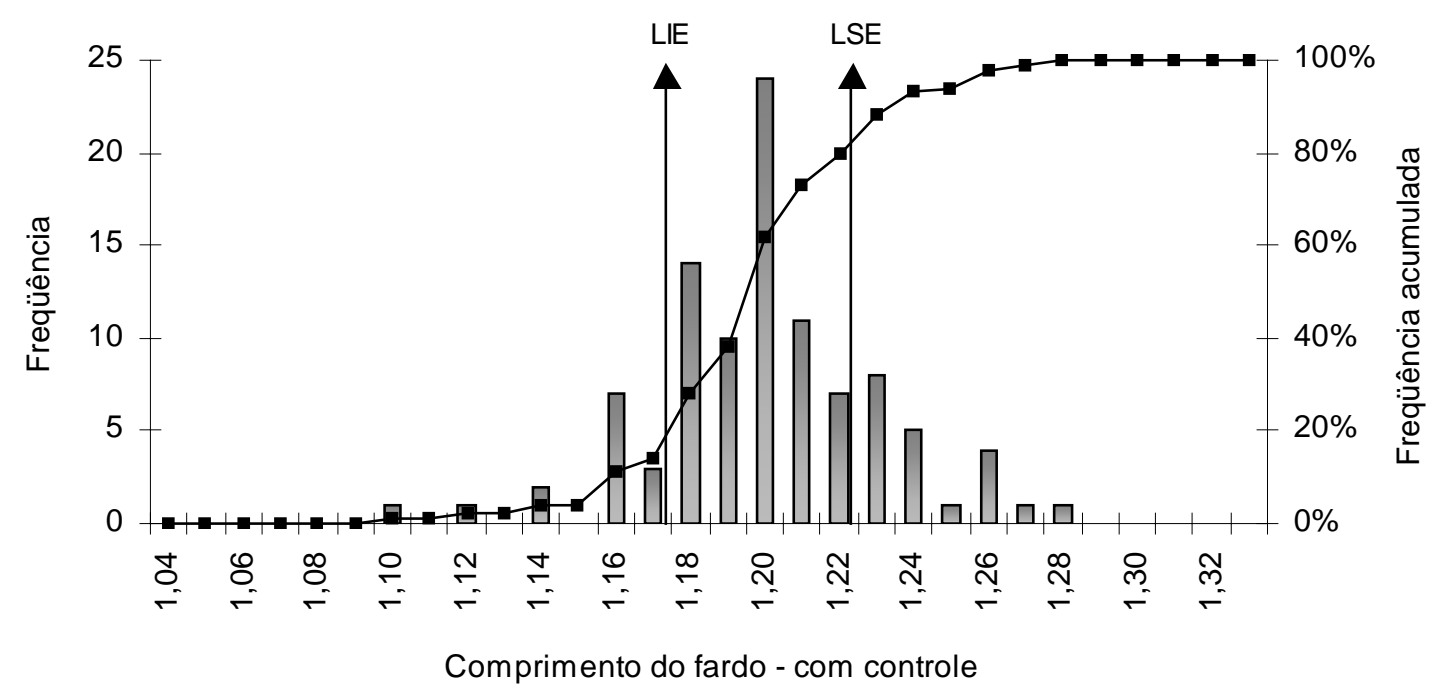

$\square$ Freqüência $\longrightarrow$ \% cumulativo

Figura 24 - Histograma da distribuição do comprimento interno do fardo, com a utilização do sistema eletrônico de contagem 
De modo análogo ao realizado na avaliação da operação de enfardamento através de contagem manual dos ciclos de prensagem, correlacionou-se o número de ciclos da prensa ao comprimento dos fardos. As Figuras 25 e 26 trazem, respectivamente, os gráficos de correlação para as situações não controlada e controlada pelo sistema eletrônico de contagem.

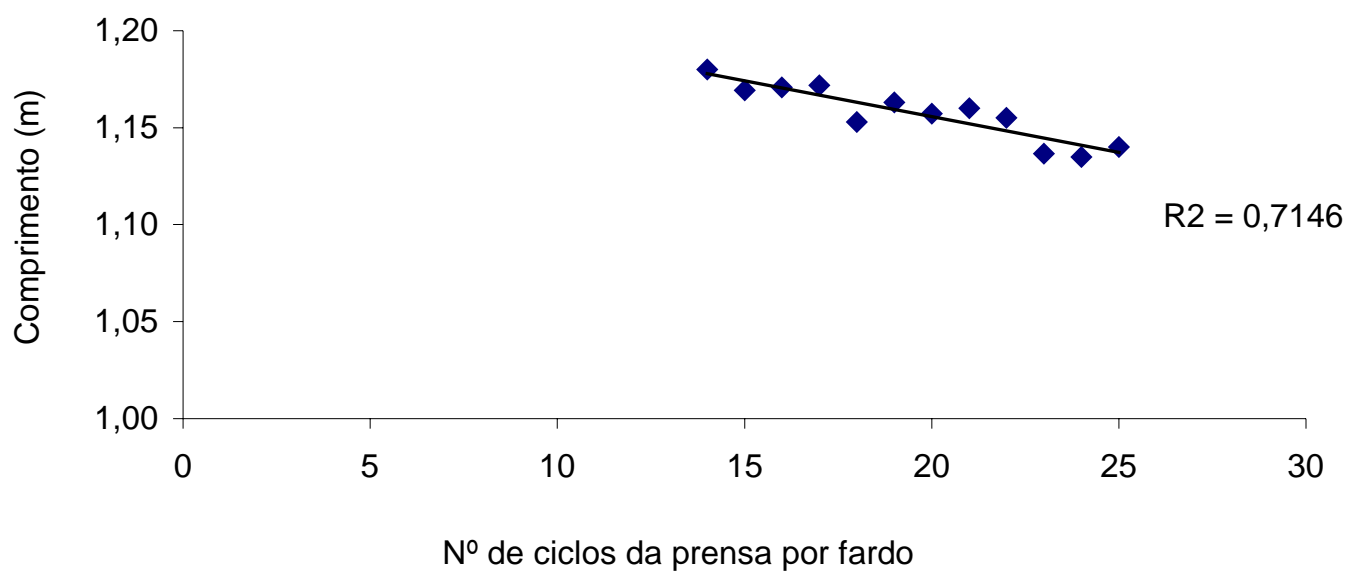

Figura 25 - Gráfico de correlação entre número de ciclos da prensa da enfardadora e comprimento interno dos fardos, para a operação executada sem o auxílio do sistema eletrônico de contagem

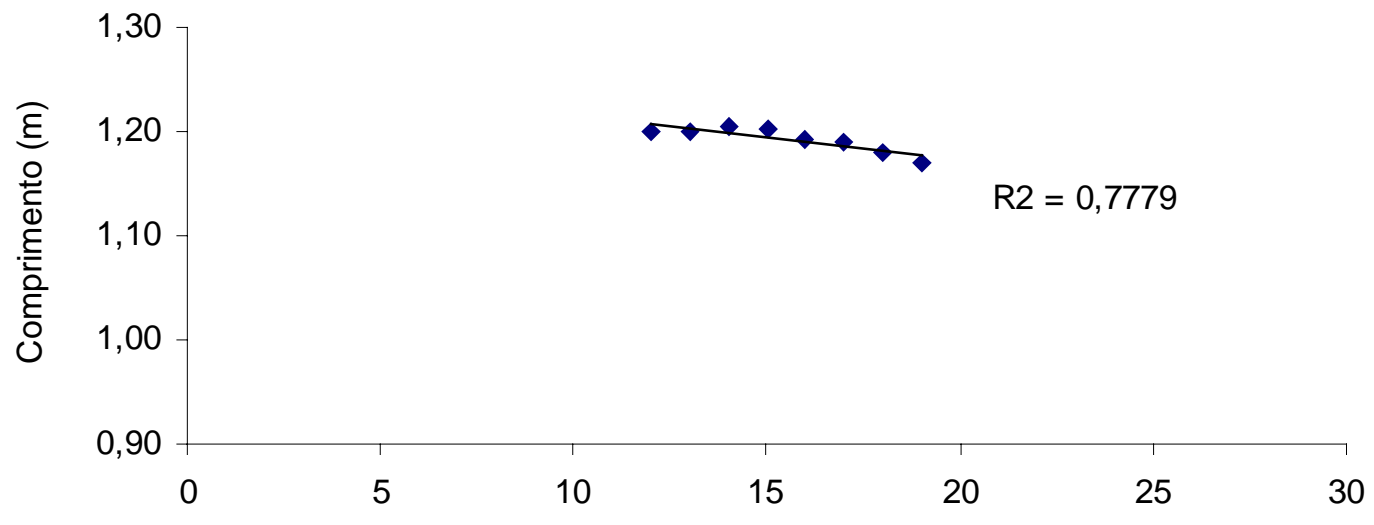

Número de ciclos do prensa por fardo

Figura 26 - Gráfico de correlação entre número de ciclos da prensa da enfardadora e comprimento interno dos fardos para a operação executada com o auxílio do sistema eletrônico de contagem 
Para ambas as situações, com e sem controle eletrônico, nos gráficos das Figuras 25 e 26 obteve-se um $\mathrm{R}^{2}$ elevado e apontaram a correlação negativa para o comprimento do fardo com aumento do número de ciclos, ou seja, o aumento do número de ciclos proporciona diminuição do comprimento do fardo.

Nos dois gráficos de correlação, os pontos entre 12 e 16 ciclos apresentaram fardos com comprimentos próximos a $1,18 \mathrm{~m}$, assim a manutenção do número de ciclos nesta faixa é confirmada como ideal às condições apresentadas na propriedade.

Por fim, uma outra característica de comprimento do fardo deve ser analisada. A enfardadora avaliada possui o sistema de corte da massa vegetal no lado esquerdo da prensa, portanto todas as medições de comprimento neste trabalho também foram tomadas no lado esquerdo do fardo a fim de se evitar distorções de mensuração. Desta forma, a realização de um estudo comparativo da influência do número de ciclos da prensa e a diferença de comprimento entre lados do fardo é importante para que se possa conhecer a uniformidade entre os lados e evitar fardos tortos, como o da Figura 27.

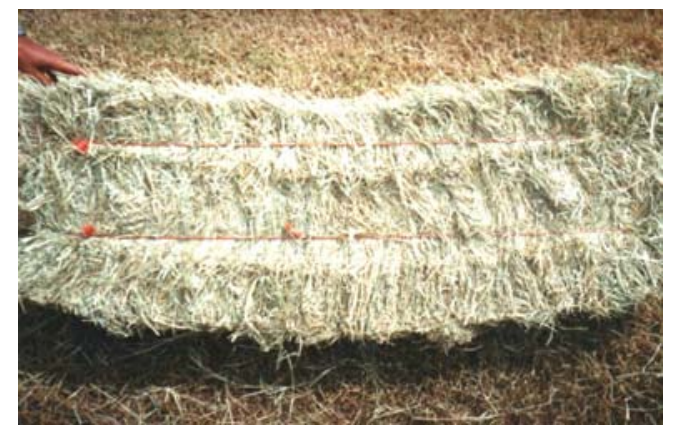

Figura 27 - Vista superior de um fardo com lados desuniformes

Fardos com comprimentos desuniformes prejudicam a operação de recolhimento, uma vez que grande parte deles se rompem durante a operação de recolhimento. Os equipamentos utilizados nessa operação tem como princípio realizar o recolhimento através de correntes denteadas e a desuniformidade reduz a capacidade operacional e causa perdas de matéria prima, onerando o sistema. 
Desta forma, na coleta de dados o comprimento externo foi amostrado e a diferença de comprimento entre os lados do fardo pode ser visualizada na Figura 28.

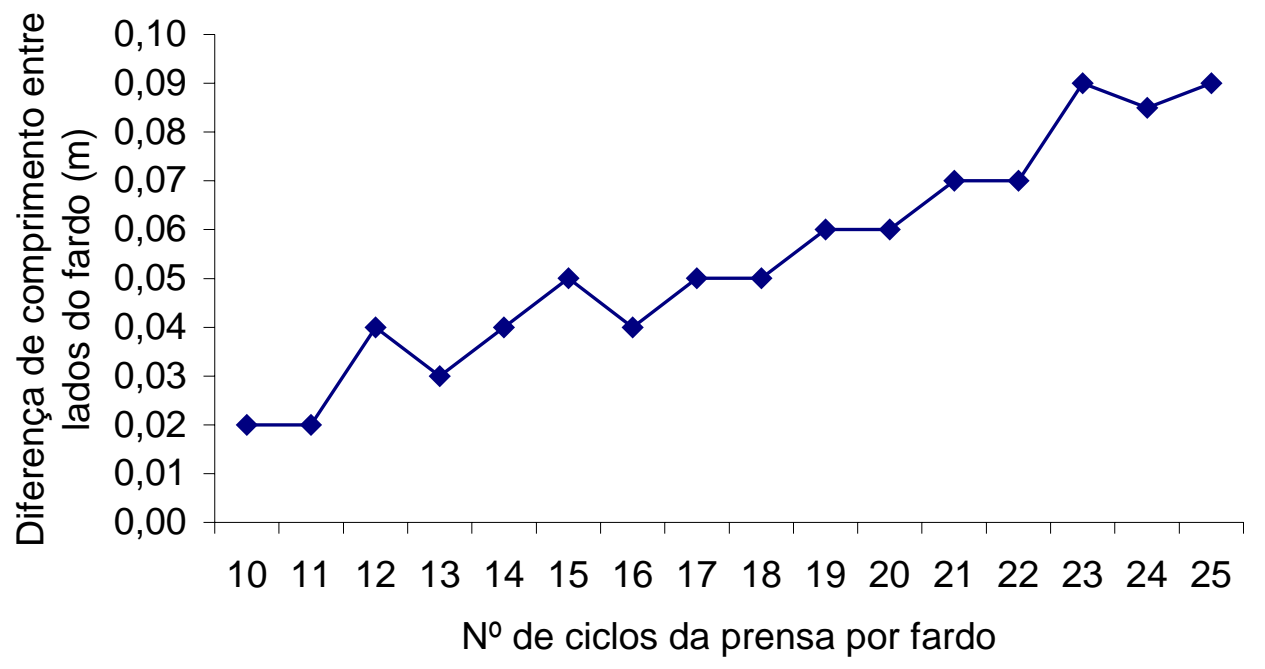

Figura 28 - Gráfico da diferença média entre os comprimentos interno e externo dos fardos

$\mathrm{Na}$ Figura 28, com a visualização da diferença entre os comprimentos interno e externo do fardo, fica clara que para a faixa especificada pela propriedade (entre 12 e 16 ciclos por fardo) a diferença entre os comprimentos é baixa, ficando entre 2 e $5 \mathrm{~cm}$, a qual não compromete a uniformidade do fardo e conseqüentemente a qualidade das operações mecanizadas subseqüentes.

Pode-se também constatar na Figura 28, que o aumento do número de ciclos gera maior desuniformidade entre os comprimentos interno e externo dos fardos. Para confirmar esta tendência, o número de ciclos foi correlacionado à diferença entre comprimentos no fardo, obtendo-se o gráfico da Figura 29. 


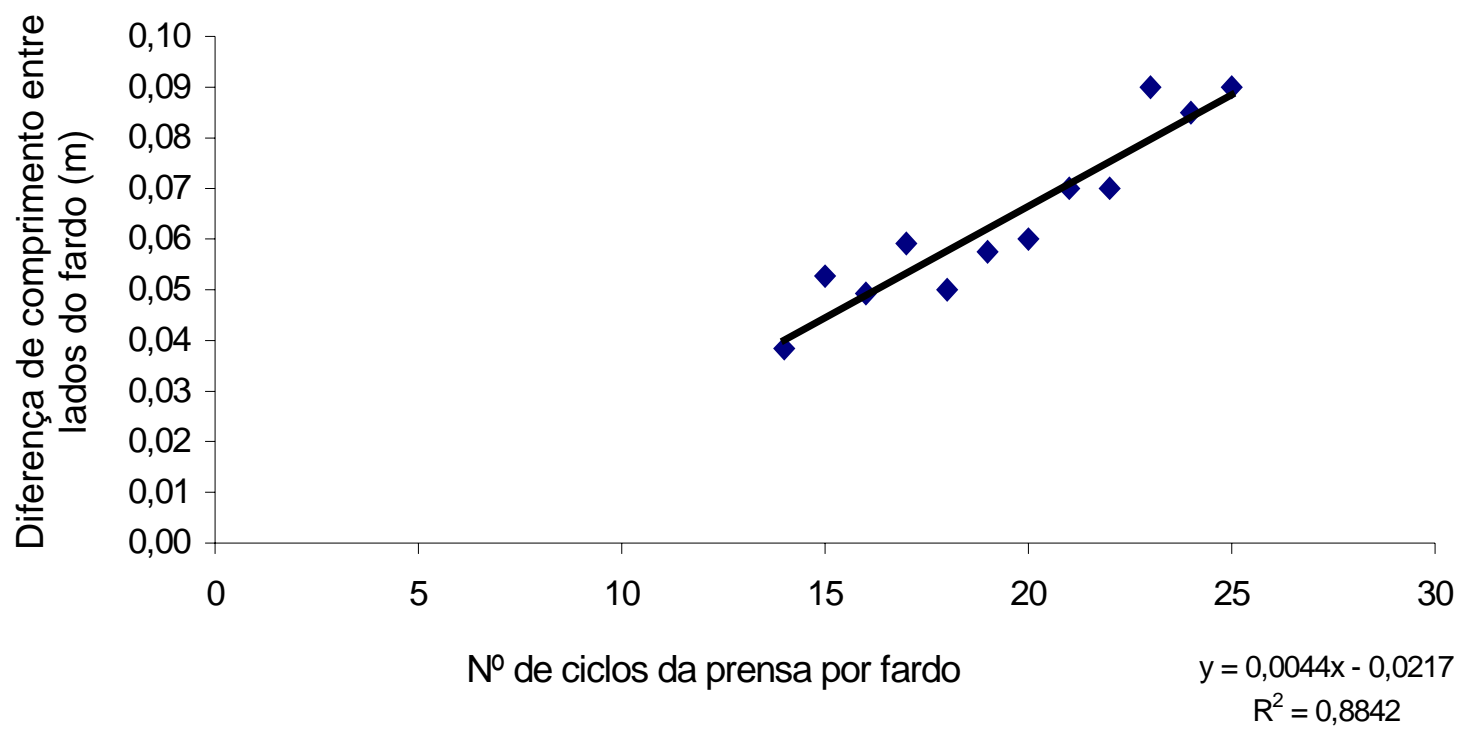

Figura 29 - Gráfico de correlação entre número de ciclos da prensa da enfardadora e a diferença média de comprimento entre os lados do fardo

O gráfico da Figura 29 apresenta um $\mathrm{R}^{2}$ de 0,88 para a correlação entre 0 número de ciclos e a diferença entre comprimentos do fardo, o que indica que quanto maior o número de ciclos mais desuniforme torna-se o fardo.

Deste modo, o sistema eletrônico de contagem pode também auxiliar na manutenção da uniformidade dos comprimentos do fardo. Portanto, sendo a operação de enfardamento realizada na faixa estipulada pela propriedade, garante-se o comprimento pretendido do fardo e sua adequada geometria. 
- Introdução do Sistema de Posicionamento Global e memória para armazenamento dos ciclos de prensagem ao sistema eletrônico de contagem.

A inclusão do GPS ao sistema eletrônico de contagem dos ciclos de prensagem possibilitou a aquisição de dados para todos os fardos produzidos na data da amostragem. Desta forma, a análise dos dados pôde ser aprofundada e ampla, correlacionando-se as eventuais causas especiais de atuação no processo às condições pontuais da operação de enfardamento. No gráfico da Figura 30 tem-se a distribuição georeferenciada dos fardos amostrados na área selecionada para o estudo.

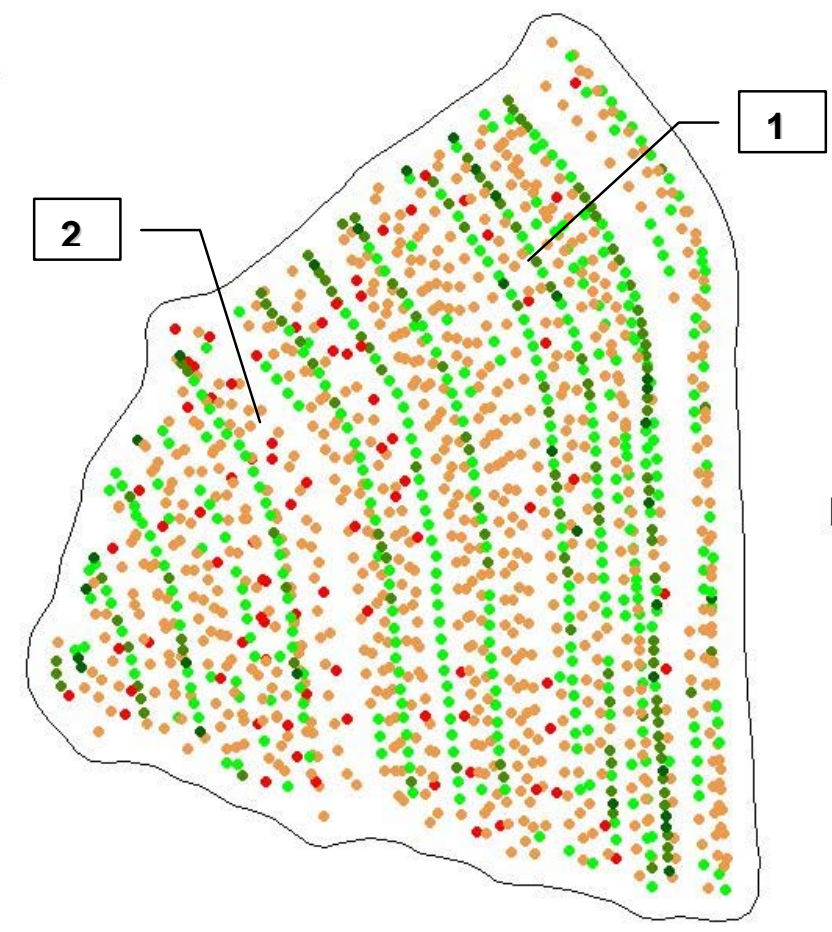

$$
\begin{array}{ll}
\text { PRODUTIVIDADE (t de ms.ha } & -1 \\
\text { - } & 0-5000 \\
: & 5000-10000 \\
: & 10000-15000 \\
- & 15000-20000 \\
-\quad & 20000-40000
\end{array}
$$

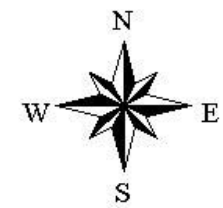

Figura 30 - Gráfico de posicionamento dos fardos no campo, com a introdução do GPS ao sistema eletrônico de contagem dos ciclos de prensagem 
A Figura 31 traz os gráficos de controle para a média (A) e amplitude (B) referentes ao número de ciclos da prensa por fardo, com a introdução do GPS ao sistema eletrônico de contagem dos ciclos da prensa. Verifica-se que o processo encontra-se fora de controle para a média, porém a variação da amplitude está dentro dos limites de controle, indicando que a variação das amostras não é puramente casual. Provavelmente as causas deste fato devem estar relacionadas primeiramente à elevada produtividade do talhão $\left(8,5\right.$ t.ha $\left.{ }^{-1}\right)$, uma vez que a amostragem ocorreu no mês de janeiro, um mês com elevado índice pluviométrico e, portanto, de poucos períodos aptos à fenação.

Analisando-se de forma mais específica o gráfico de controle para a média de ciclos da enfardadora por fardo (Figura $31 \mathrm{~A}$ ), constata-se que no horário de 18:15 o número de ciclos está abaixo do limite inferior de controle e para o horário de 20:30 a quantidade de ciclos encontra-se acima do limite superior de controle. No gráfico de posicionamento dos fardos (Figura 30), há dois pontos destacados: o ponto indicado com o número 1 refere-se ao início da seqüência de fardos com média inferior ao limite e o número 2 refere-se ao início da seqüência de fardos com média superior ao limite.

Desta forma, pode-se atribuir a quantidade inferior de ciclos de prensagem no ponto 1 a uma maior largura de trabalho do ancinho enleirador, que pela proximidade a uma curva de nível, fez duas passadas e formou uma leira com maior quantidade de massa vegetal. Devido a esta quantidade elevada de massa vegetal na leira, pode-se visualizar a menor distância entre fardos na leira em questão e, conseqüentemente, o operador não reduziu suficientemente a velocidade do conjunto mecanizado, o que acabou por diminuir o número de ciclos dos fardos formados nesta leira.

Já no ponto 2 indicado na Figura 30, referente ao início da seqüência de fardos com média de ciclos acima do limite, nota-se que se trata de uma área de baixa produção e conseqüentemente, o operador não elevou a velocidade de operação do conjunto mecanizado para que a quantidade de massa vegetal processada pela enfardadora se mantivesse constante. 

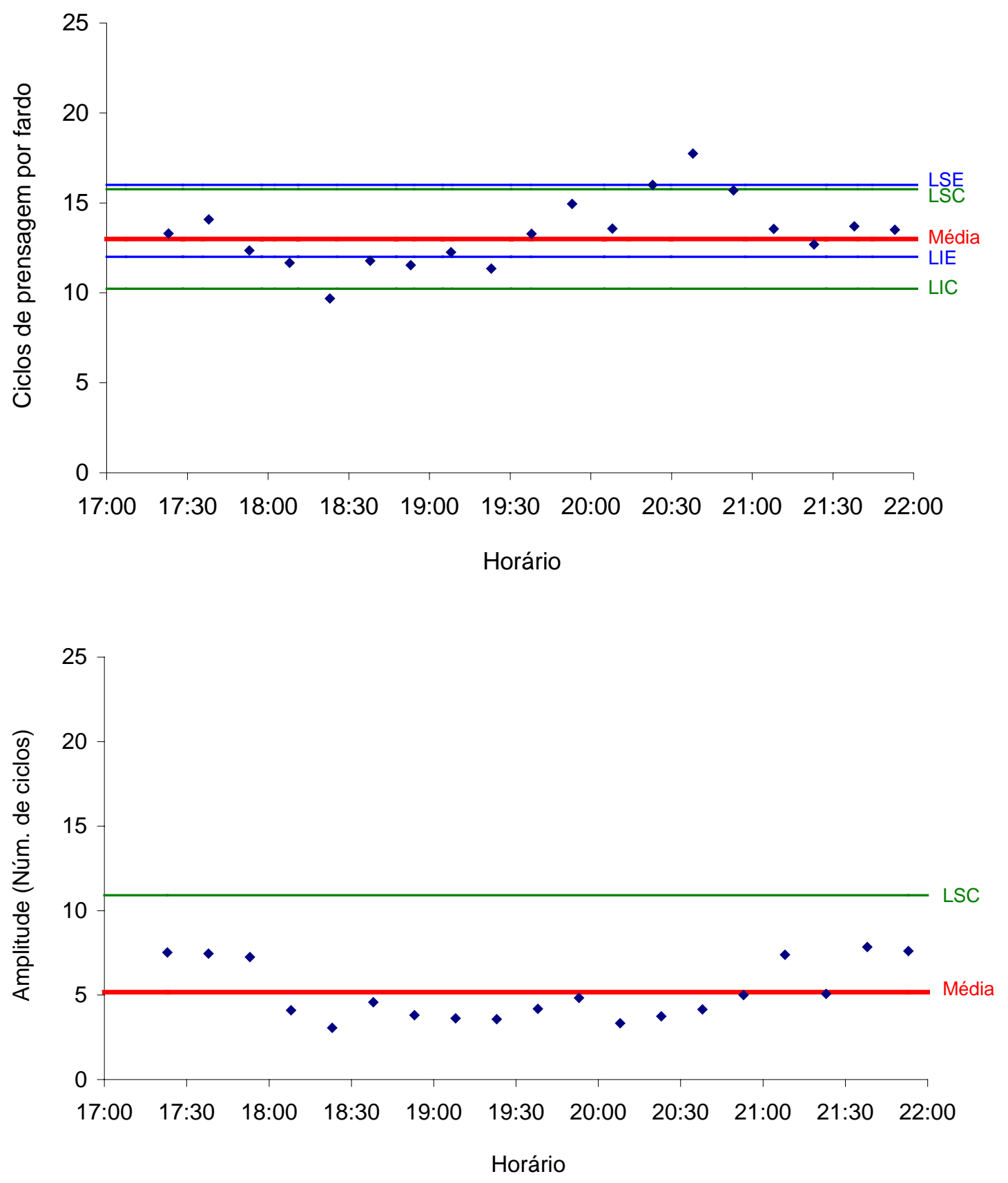

Figura 31 - Gráfico de controle para a média e amplitude do $\mathrm{n}^{0}$ de ciclos da prensa da enfardadora por fardo, com GPS acoplado ao controle eletrônico de contagem; (LSC: Limite Superior de Controle; LIC: Limite Inferior de Controle; LSE: Limite Superior de Especificação; LIE: Limite Inferior de Especificação) 
De forma geral, a operação de enfardamento com a utilização do sistema eletrônico de contagem acoplado ao GPS atende à qualidade exigida pela empresa, uma vez que a média para a operação é de 13 ciclos de prensagem por fardo. Tem-se também que a amplitude dos pontos também não variou de forma significativa, variando entre 3 e 8 ciclos por fardo ao longo de todo o dia de trabalho.

Na Figura 32 tem-se o histograma da distribuição do número de ciclos de prensagem por fardo para esta avaliação, utilizando-se o GPS acoplado ao sistema eletrônico de contagem.

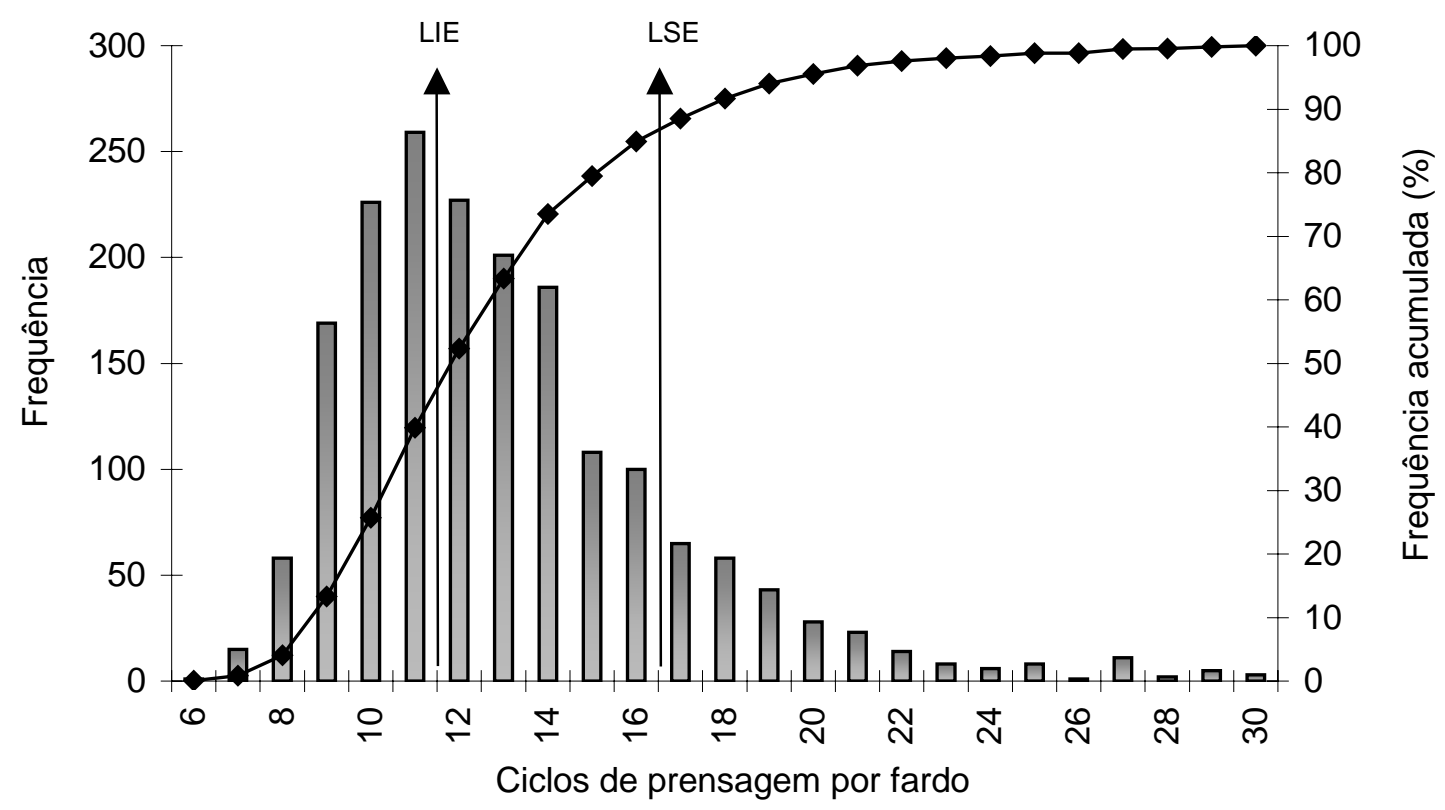

$\square$ Frequência $\multimap$ Frequência acumulada (\%)

Figura 32 - Histograma da distribuição do número de ciclos da prensa da enfardadora por fardo, com a utilização do GPS acoplado ao sistema eletrônico de contagem

O histograma da Figura 32 aponta que $45 \%$ de todos os fardos produzidos no dia da amostragem encontram-se dentro dos limites de especificação 
estipulados pela empresa e que 39\% estão abaixo do limite inferior. Porém destes 39\% de fardos formados com menos de 12 ciclos, 26\% estão entre 10 e 11 ciclos, o que indica uma boa proximidade à faixa de trabalho pretendida. Importante frisar também que apenas $16 \%$ de todos os fardos amostrados estão sendo formados acima do limite superior.

Assim, pode-se afirmar que com a introdução do GPS ao sistema eletrônico de contagem dos ciclos de prensagem, a operação foi monitorada de forma mais eficiente, conseguindo-se amostrar a totalidade dos pontos ao longo da jornada de trabalho, bem como a localização destes pontos na área, o que viabiliza um diagnóstico mais preciso das causas que influenciam no processo.

Por fim, a obtenção das coordenadas geográficas para fardo aliado ao peso médio dos fardos, permitiu a geração de um mapa de produtividade para a área amostrada, como pode ser visto na Figura 33.
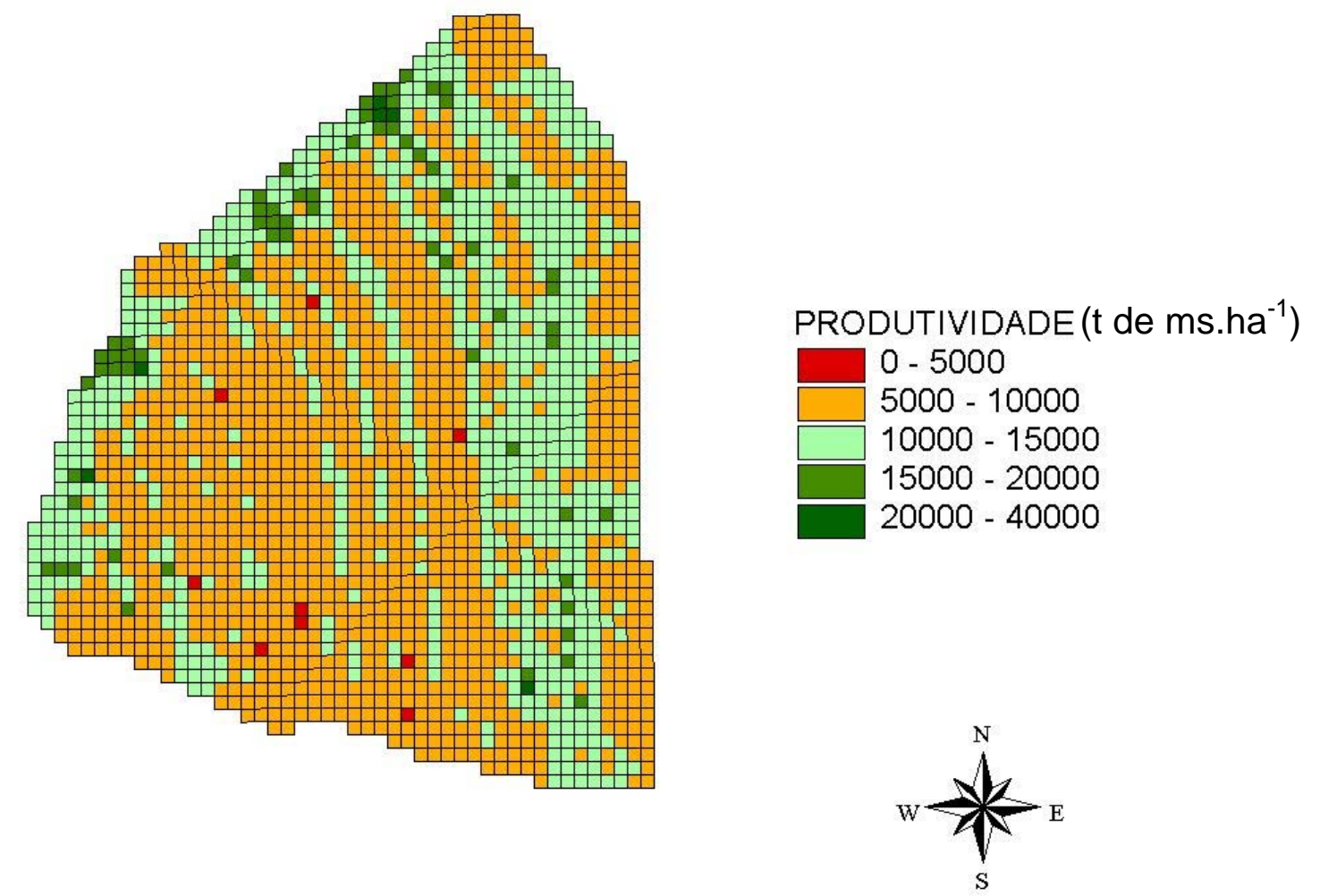

Figura 33 - Mapa de produtividade para a cultura de feno 
O objetivo deste trabalho não foi a geração do mapa de produtividade para a cultura do feno, desta forma a precisão do GPS utilizado, bem como os métodos de tratamento dos dados não permitem a realização de inferências precisas sobre o mapa, somente visualizar que a faixa de maior produtividade está entre 5 e 10 mil kg de $\mathrm{ms}$ ha $^{-1}$.

Portanto, o uso de Agricultura de Precisão no controle da qualidade das operações mecanizadas de fenação mostra-se viável e com um grande potencial a ser explorado por esta união. 


\section{CONCLUSÕES}

A implantação de um sistema de controle de qualidade em operações agrícolas mecanizadas para a cultura do feno mostrou-se eficiente, sendo possível identificar e quantificar os pontos críticos das operações. As operações de sega e enfardamento foram consideradas críticas sob o ponto de vista econômico e qualitativo em relação ao produto final (feno).

Para a operação de sega, os resultados indicaram que existem causas especiais atuando no processo que podem estar relacionadas com as condições fisiográficas da propriedade. Constatou-se também a tendência de execução da operação acima dos limites estabelecidos, devido ao receio de contaminação da massa ceifada.

Já na operação de enfardamento também foi constatado que causas especiais estão agindo sobre o processo. Das operações analisadas, a de enfardamento é a que apresenta um maior potencial de melhoria, e para tanto exigiu que um dispositivo de contagem fosse acoplado ao equipamento. Desta forma, o sistema eletrônico de contagem do número de ciclos de prensagem por fardo mostrou-se eficiente, auxiliando na melhoria da qualidade da operação, tanto sob o aspecto de manutenção do comprimento adequado, quanto de uniformidade na geometria do fardo.

Os limites especificados pela empresa, com relação ao número de ciclos da prensa por fardo (entre 12 e 16) atendem às exigências de comprimento e uniformidade do fardo. 
A correlação entre o número de ciclos de prensagem e o tamanho do fardo é significativa, atendendo diretamente a uma característica do produto final. Portanto, o aumento do número de ciclos da prensa proporciona diminuição do comprimento do fardo. Tem-se também que o aumento do número de ciclos por fardo resulta em maior desuniformidade do fardo.

A inclusão do GPS ao sistema eletrônico de contagem dos ciclos de prensagem demonstrou-se eficiente na detecção dos pontos obtidos fora dos limites de controle ou especificação, agregando maior detalhamento ao processo de controle da qualidade das operações mecanizadas de fenação.

\subsection{Sugestões para estudos futuros}

Como primeira sugestão para trabalhos futuros, deve-se ampliar o uso do CEP na avaliação das demais operações do sistema mecanizado de fenação, visto a melhoria do processo obtida no controle das operações de sega e enfardamento.

Outra importante sugestão é a realização de um estudo aprofundado no uso do GPS acoplado ao sistema eletrônico de contagem de ciclos, comparando-se os dados obtidos pelo uso do GPS de navegação ao de um DGPS, avaliando se a diferença entre os sistemas é significativa e se o custo adicional do sistema de DGPS é compensado pela melhoria ao sistema.

Por fim, a introdução de um sistema de medição do peso individual dos fardos acoplado ao sistema eletrônico de contagem seria bastante interessante, uma vez que se poderia monitorar e relacionar os dois fatores (ciclos e peso) de todos os fardos produzidos e com isto realizar um acompanhamento gerencial da operação. 
ANEXOS 
Anexo A - Tabela dos fatores para construção das cartas de controle X-R

\begin{tabular}{|c|c|c|c|}
\hline $\begin{array}{l}N^{\circ} \text { de observações no } \\
\text { grupo de amostras (n) }\end{array}$ & $A_{2}$ & $\mathrm{D}_{3}$ & $\mathrm{D}_{4}$ \\
\hline 2 & 1,880 & 0 & 3,267 \\
\hline 3 & 1,023 & 0 & 2,575 \\
\hline 4 & 0,729 & 0 & 2,282 \\
\hline 5 & 0,577 & 0 & 2,115 \\
\hline 6 & 0,483 & 0 & 2,004 \\
\hline 7 & 0,419 & 0,076 & 1,924 \\
\hline 8 & 0,373 & 0,136 & 1,816 \\
\hline 9 & 0,337 & 0,184 & 1,816 \\
\hline 10 & 0,308 & 0,223 & 1,777 \\
\hline 11 & 0,285 & 0,256 & 1,744 \\
\hline 12 & 0,266 & 0,283 & 1,717 \\
\hline 13 & 0,249 & 0,307 & 1,693 \\
\hline 14 & 0,235 & 0,328 & 1,672 \\
\hline 15 & 0,223 & 0,347 & 1,653 \\
\hline 16 & 0,212 & 0,363 & 1,637 \\
\hline 17 & 0,203 & 0,378 & 1,637 \\
\hline 18 & 0,194 & 0,391 & 1,608 \\
\hline 19 & 0,187 & 0,403 & 1,597 \\
\hline 20 & 0,180 & 0,415 & 1,585 \\
\hline 21 & 0,173 & 0,425 & 1,575 \\
\hline 22 & 0,167 & 0,434 & 1,566 \\
\hline 23 & 0,162 & 0,443 & 1,557 \\
\hline 24 & 0,157 & 0,451 & 1,548 \\
\hline 25 & 0,153 & 0,459 & 1,541 \\
\hline
\end{tabular}

Fonte: VIEIRA (1999), citando Montgomery, D.C., Statistical Quality Control, NY, 1991. 
Anexo B - Mapa da propriedade localizada no município de Água Comprida/MG

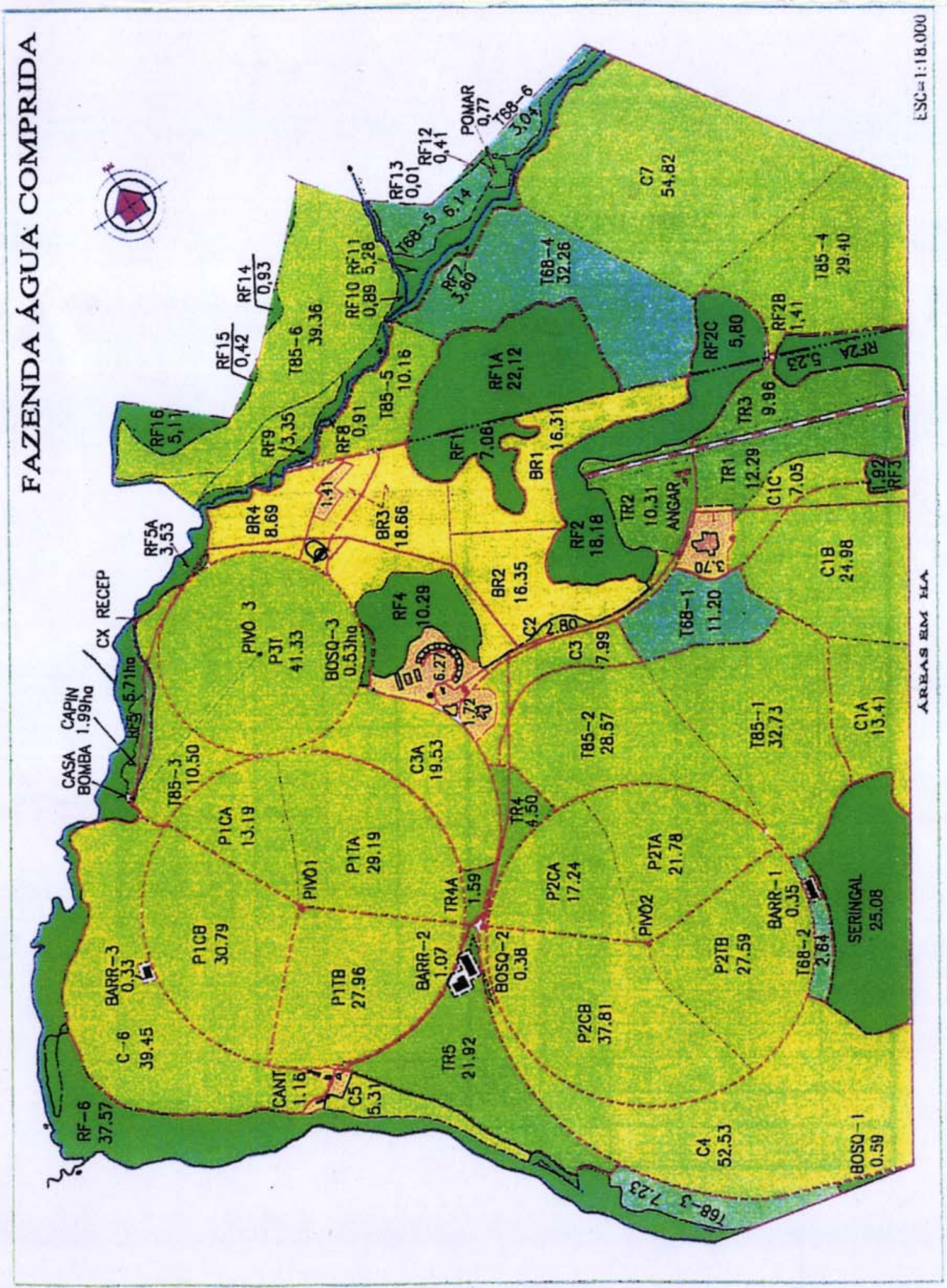


Anexo C - Fluxograma da seqüência de operações realizadas no sistema de produção e requisitos necessários para a adequada realização da fenação

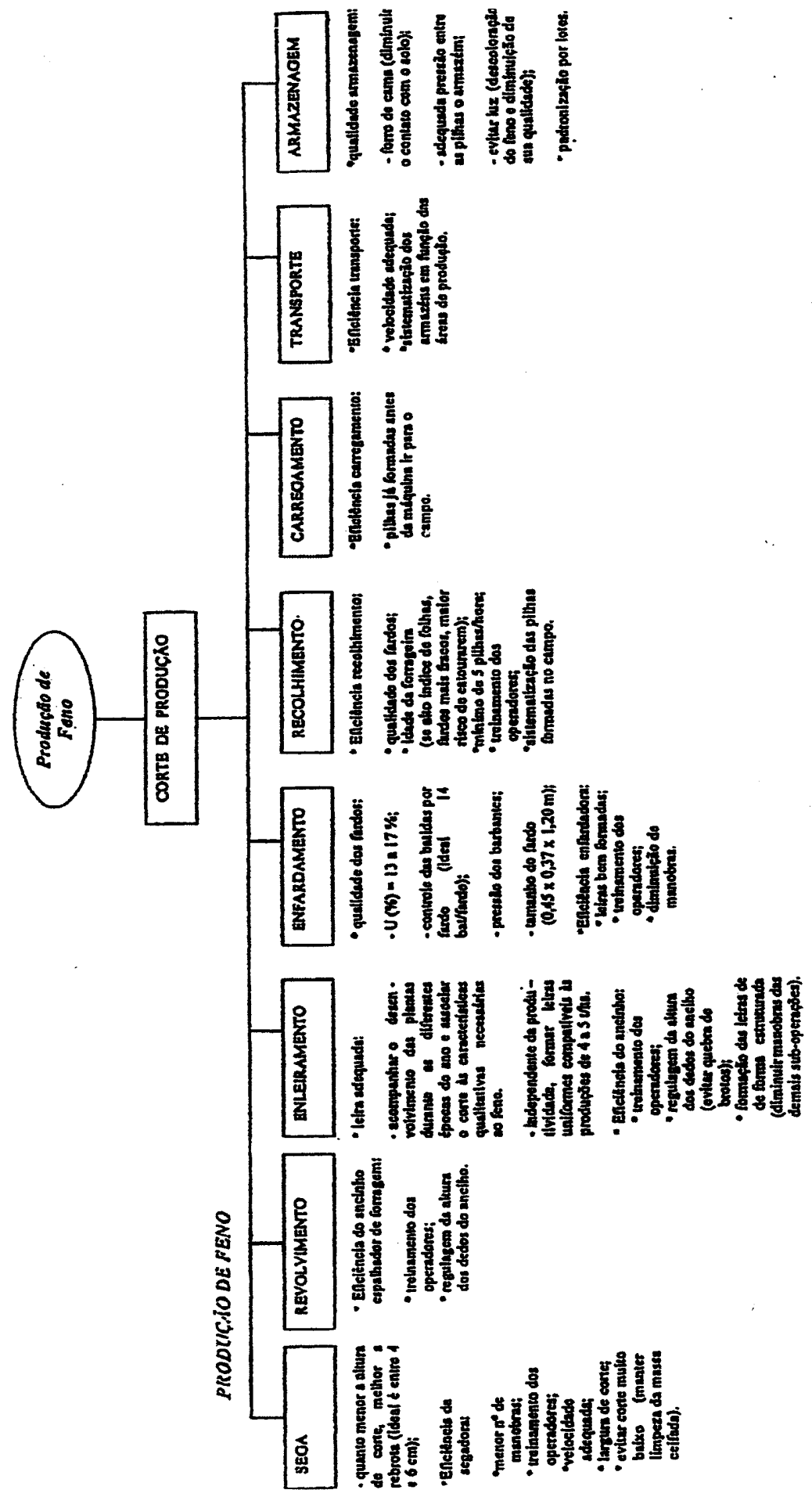


Anexo D - Características técnicas do sistema eletrônico de contagem dos ciclos de prensagem, utilizando as informações georeferenciadas enviadas pelo GPS

\section{Características técnicas:}

- 1 display LCD de 2 linhas/16 caracteres para exibição de dados e do menu de operações.

- 1 botão para seleção das funções: Exportar dados, Limpar dados e Sair.

- 1 conector DB9, padrão RS-232 para interface com computador padrão IBM-PC.

- 1 conector para entrada dos sensores (Fardo e Ciclo).

- 1 conector para entrada da energia (12Vdc +5\%, -10\%).

- 1 conector para entrada da antena do GPS.

- 1 Buzzer que sinaliza quando o numero de ciclos para o fardo está fora do valor previsto (13 a 15).

As sentenças geradas e armazenadas no datalog seguem o seguinte formato:

$$
\text { "FF,HHMMSS,DDMM.mmmm,d,DDDMM.mmmm,d,q" }
$$

Onde:

$\mathrm{FF}=$ ciclos de prensagem por fardo

HHMMSS = Hora UTC (Coordinated Universal Time): hora de referência em relação ao Meridiano de Greenwich, sob o formato o 24 h. No Brasil, deve ser defasada em $2 \mathrm{~h}$. 
DDMM.mmmm,d: Coordenada 1

Nota: DD: $\quad$ Degree (00..90)

MM.mmmm: Minutes (00.000..59.9999)

d: $\quad$ Direction, N-north, S-south

DDDMM.mmmm,d: Coordenada 2

Nota: DD: $\quad$ Degree (00..180)

MM.mmmm: Minutes (00.000..59.9999)

d: $\quad$ Direction, E-east, W-west

$q=$ Indicador do tipo se sinal do GPS

Nota: 0: $\quad$ Sem sinal - Fix não disponível ou invalido.

1: $\quad$ GPS modo SPS, Fix valido.

2: $\quad$ Diferencial, modo PPS, Fix valido.

3: $\quad$ GPS modo PPS, Fix valido.

Obs.: - Dados extraídos da sentença "GGA" padrão NMEA 0183.

- Envio dos caracteres em ASCII, com campos separados por virgula, com um CR/LF (retorno de carro e fim de linha) para cada sentença enviada. 
Anexo E: Fluxograma da seqüência de informações georeferenciadas adquiridas e processadas pelo sistema eletrônico de contagem dos ciclos de prensagem

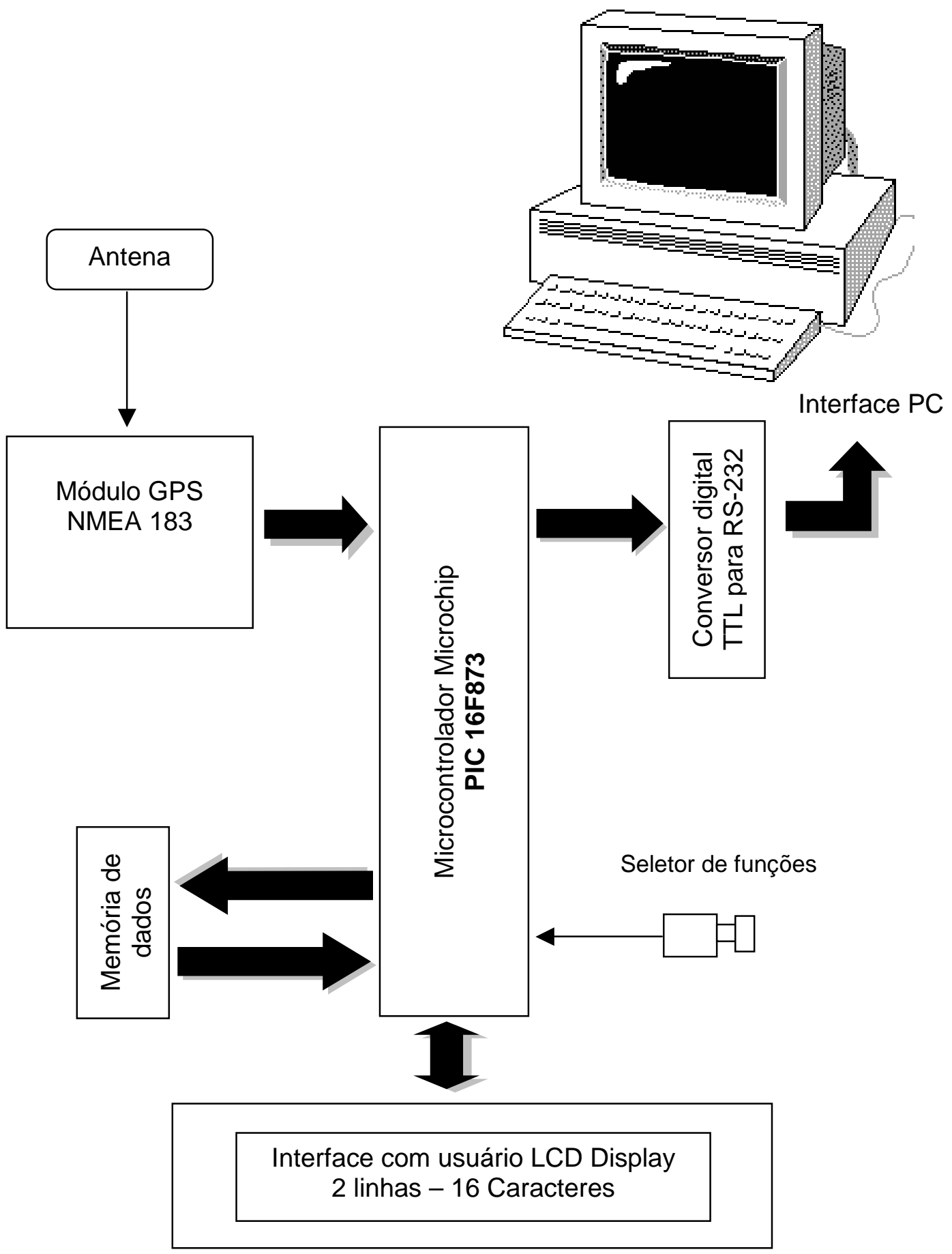




\section{REFERÊNCIAS BIBLIOGRÁFICAS}

ALVIM, M.J.; RESENDE, H.; BOTREL, M. A., Efeito da freqüência de cortes e do nível de nitrogênio sobre a produção e qualidade da matéria seca do Coastcross. Juiz de Fora : EMBRAPA, CNPGL, 1996. 181 p.

AMERICAN SOCIETY OF AGRICULTURAL ENGINEERS. ASAE standards 2001: standards, engineering practices, and data. 48. ed. St. Joseph. 2001a. p. 354-355: ASAE S495: uniform terminology for agricultural machinery management.

ANDRIANI, C. S. Gerenciamento pela qualidade total: apostila de treinamento. Fortaleza: FDA - Fundação de Desenvolvimento Humano Douglas Andreani, 1996. 25p.

ANTUNES, L.M.; ENGEL A. Agroqualidade: qualidade total na agropecuária. Guaíba : Agropecuária, 1999. 113 p.

BALASTREIRE, L.A., O estado da arte da agricultura de precisão no Brasil. Piracicaba: O autor, 2000. 222 p.

BANCHI, AD.; GONÇALVES, N.H.; LIMA, E.B.; PINTO, R.S.A; LOPES, J.R. Eficiência de uso de máquinas agrícolas. STAB. Açúcar, Álcool e Subproduto, v.73, p.165-168, abril/maio 1994. 
BARBOSA, M.M.; MILAN, M.; COELHO, J.L.D.; Planning of na agricultural machinery system. In: INTERNATIONAL CONFERENCE ON COMPUTERS IN AGRICULTURE, Orlando, 1998. Proceedings. Orlando: ASAE, 1998. v.7, p. $35-40$.

BONILLA, J.A. Métodos quantitativos para a qualidade total na agricultura. Contagem: Líttera Maciel, 1995. 250 p.

BRASSARD, M. Qualidade - ferramentas para uma melhoria contínua. Rio de Janeiro: Qualitymark, 1985. 87 p.

BRUGNARO, C.; SBRAGIA, R. Gerência Agrícola em destilarias de álcool. Piracicaba: IAA,1984. 211 p.

CALCERLEY, D.J.B. Métodos de conservatión de forajes. In: WILKINS, R.J. (Ed.) Conservatión de forajes. Zaragosa: Acribia, 1970. p. 27- 35.

CAMPOS, V.F., TQC - Controle da qualidade total (no estilo japonês). 8.ed. Belo Horizonte: Fundação Christiano Ottoni, 1992, 229 p.

CENTRO DE ESTUDOS AVANÇADOS EM ECONOMIA APLICADA. http://cepea.esalq.usp.br (02 jan.2004).

CHERRY, M. Conservatión de forajes. Ed. Academia S.L. Leon: 1970. 86 p.

CHIAVENATO, I. Introdução à teoria geral de administração. 3.ed., São Paulo: McGraw-Hill do Brasil, 1983. 617 p.

CLARK, R.L.; MCGUCKIN, R.L. Variable rate application technology: overview. In: INTERNATIONAL CONFERENCE ON PRECISION FARMING, 3., Minneapolis, 1996. Procedings. Madision: ASA, CSSA, SSSA, 1996. p. 855862. 
CONFEDERAÇÃO DA AGRICULTURA E PECUÁRIA DO BRASIL. Informações sobre o mercado agropecuário para o ano de 2003. http://www.cna.org.br/Informações03/ (02 jan. 2004).

CUNHA, J.L.F., BARTHOLO, M.B., O sistema de garantia da qualidade e sua importância. In: CONGRESSO BRASILEIRO DE CONTROLE DA QUALIDADE, 1., São Paulo, 1986. Resumos. São Paulo: S.N., 1986. p.21-30.

DELLARETTI FILHO, O.; DRUMOND, F.B. Itens de controle e avaliação de processos. Belo Horizonte: Fundação Christiano Ottoni, 1994. 151 p.

DODSON, M.S. Avaliação da influência de indicadores de qualidade no custo operacional de um sistema de produção de milho (Zea mays L.): estudo de caso da semeadura. Jaboticabal, 1998. 80p. Monografia (Graduação) Faculdade de Ciências Agrárias e Veterinárias, Universidade Estadual Paulista "Júlio de Mesquita Filho".

FARIA,V.P. de. Técnicas de produção de feno. In.: SIMPÓSIO SOBRE MANEJO DA PASTAGEM, 2, Piracicaba,1975. Anais. Piracicaba: ESALQ, 1975. p. 229-240.

FARIA, V.P. de; CORSI, M. Técnicas de produção de feno. In.: PEIXOTO, A.M.; MOURA, J.C.; FARIA, V.P. Confinamento de bovinos leiteiros. Piracicaba: FEALQ, 1993. p. 171-194.

FERNANDES, R.A.T. Aplicação de conceitos da qualidade em operações mecanizadas na produção de milho (Zea mayz L.) para silagem. Piracicaba, 2000. 81 p. Dissertação (Mestrado) - Escola Superior de Agricultura "Luiz de Queiroz", Universidade de São Paulo. 
FERNANDES, R.A.T.; MILAN, M; PECHE FILHO, A., Gerenciamento da qualidade em operações mecanizadas de um sistema de produção de canade-açúcar. Revista de Engenharia Agrícola, v.20, n.3, p. 215-220, set. 2000.

FESSEL, V.A.G. Qualidade, desempenho operacional e custo de plantios, manual e mecanizado, de Eucaliptus grandis, implantados com o cultivo mínimo do solo. Piracicaba 2003. 88 p. Dissertação (Mestrado) - Escola Superior de Agricultura "Luiz de Queiroz", Universidade de São Paulo.

GITLOW, H.S., Planejando a qualidade, a produtividade e a competitividade. Rio de Janeiro: Qualitymark, 1993. 1182 p.

GOERING, C.E. How much and where. Agricultural Engeneering, v. 73, n. 4, p.13-15, July. 1992.

GOMIDE, J. A. Características de planta forrageira a ser fenada. Belo Horizonte: Feno / Tecnologia de Produção (Informativo Agropecuário), 1980. p. 6-8.

HADDAD, C.M. Produção de feno de gramíneas tropicais. Cavalo Marchador, v.6, n.53, p. 16-19, 1992.

HADDAD, C.M.; CASTRO, F.G.F., Produção de feno. In: SIMPÓSIO SOBRE MANEJO DA PASTAGEM, 15, Piracicaba, 1998. Anais. Piracicaba: FEALQ, 1998. p. 151-171.

HAN, S.; HUMMEL, J.W.; GOERING, C.E.; CAHN, M.D. Cell size for sitespecific crop management. Transactions of the ASAE, v. 37, n.1, p. 19-26, Jan/Feb, 1994. 
HUNT, D.R. Farm power and machinery management. 6. ed., Ames: lowa State University Press, 1973. 324p.

INSTITUTO BRASILEIRO DE GEOGRAFIA E ESTATÍSTICA, Dados estatísticos da produção pecuária brasileira. http://www.sidra.ibge.gov.br/ bda/pecua/default.asp (02 jan. 04).

INTERNATIONAL ORGANIZATION FOR STANDARTIZATION. ISO, Members World Wide. http://www.iso.ch/. (20 nov. 2002).

JACOVINE, L.A.G. Gestão da qualidade na colheita de madeira em povoamentos eqüiâneos. Viçosa, 2000. 136 p. Tese (Doutorado) Universidade Federal de Viçosa.

JURAN, J.M. Juran planejando para a qualidade. São Paulo: Pioneira, 1990. $394 \mathrm{p.}$

LAVEZZO, W.; ANDRADE, J.B., Conservação de forragens: feno e silagem. In: SIMPÓSIO BRASILEIRO DE FORRAGEIRAS E PASTAGENS, Campinas: CBNA, 1994. p. 105.

LEAL, J.C.G. Mapeamento da produtividade na colheita mecanizado do café. Piracicaba, 2002. 89 p. Dissertação (Mestrado) - Escola Superior de Agricultura "Luiz de Queiroz", Universidade de São Paulo.

LOPES, M.B.; LUNARDI FILHO, D.; PECHE FILHO, A.; COELHO, J.L.D.; MILAN, M., Qualidade em operações agrícolas mecanizadas na cultura de cana-deaçúcar. STAB. Açúcar, Álcool e Subprodutos, Piracicaba, v.13, n.3, jan./fev. 1995. p 26-30. 
LOPES, M.B.; MILAN, M., Simulation of a sugar cane loading and transport system. In: INTERNATIONAL CONFERENCE ON COMPUTERS IN AGRICULTURE, Orlando, 1998. Proceedings. Orlando: ASAE, 1998. v.7, p. 124 - 130.

MAC DONALD, A.D.; CLARCK E.A. Water and quality loss during field drying of hay. Advances in Agronomy, v.41, p.407-437,1989.

MIALHE, L.G. Manual de mecanização agrícola. São Paulo: Agronômica Ceres, 1974. 301p.

MIALHE, L.G., Máquinas agrícolas: ensaios \& certificação. Piracicaba: FEALQ, 1996. 722p.

MILAN, M.; CROSSLEY, C.P., Improving operational management on harvest transport and mechanization for sugar cane. In: INTERNATIONAL CONFERENCE ON COMPUTERS IN AGRICULTURE, Orlando, 1998. Proceedings. Orlando: ASAE, 1998. v.7, p. 108 - 116.

MILAN, M,; FERNANDES, R.A.T., Qualidade das operações de preparo de solo por controle estatístico de processo. Scientia Agricola, n. 59, n. 2, p.261266, abr/jun 2002.

MINSON, D.J. Forage in ruminant nutrition. San Diego: Academic Press, 1990. $483 \mathrm{p}$.

MIRANDA, R.L. Qualidade total: rompendo as barreiras entre a teoria e a prática. São Paulo: Makron Books, 1994. 203 p. 
MOLIN, J.P.; MILAN, M. Adequação do trator ao implemento e ao tipo de solo (compact disc). In: SEMINÁRIO SOBRE MÉTODOS E EQUIPAMENTOS DE PREPARO DE SOLO PARA O PLANTIO DE FLORESTAS, Piracicaba, 2000. Resumos. Piracicaba:IPEF, 2000. p. 9-16.

MONTGOMERY, D.C. Introduction to statistical quality control. New York: John Wiley, 1996. 677p.

OZKAN, H. E. ; HOLMES R. G., Determining machinery timeliness cost in corn planting using DRAINMOD. Transaction of the ASAE, v. 33. n. 3, 1990. p.718-724.

PASQUA, S.E. Gerenciamento da qualidade de operações agrícolas mecanizadas em um sistema conservacionista de produção de milho (Zea mays L.). Piracicaba, 1995. 67 p. Monografia (Graduação) - Escola Superior de Agricultura "Luiz de Queiroz", Universidade de São Paulo.

PASQUA, S.E. Controle da qualidade em operações agrícolas mecanizadas. In: CONSELHO NACIONAL DE DESENVOLVIMENTO CIENTÍFICO E TECNOLÓGICO. Prêmio Jovem Cientista 1995: publicação resumida dos trabalhos vencedores. Porto Alegre: CNPq; Fundação Roberto Marinho; Grupo Gerdau, 1999. p. 53-84.

PECHE FILHO, A.; COSTA, J.A.; FERRETI, G.; STORINO, M. Avaliação do grau de picagem de material orgânico: uma proposta de metodologia. In: CONGRESSO BRASILEIRO DE ENGENHARIA AGRÍCOLA, 23., Campinas, 1994. Resumos. Campinas: UNICAMP; SBEA, 1994. p.252. 
PEREIRA, J.R.A.; REIS, R.A. Feno. In: SIMPÓSIO SOBRE NUTRIÇÃO DE BOVINOS - ALIMENTAÇÃO SUPLEMENTAR, 7., Piracicaba, 1999. Anais. Piracicaba: FEALQ, 1999. p. 123 - 146.

PIZARRO, E.A.; SATURNINO, M.A.C.;MELO, J.C. Custos produção e armazenamento de feno. Informe Agropecuário, v. 6, n. 64, abr. 1980. p. 28-30.

PRADO, H. Os solos do estado de São Paulo: mapas pedológicos. Piracicaba: S.N., 1997. 205 p.

RAYMOND, F.; SHEPPERSON G.; WALTHAN R. Forage conservation and feeding. 3. ed., Suffolk: Farming Press, 1978. 208 p.

REEVES, C.A.; BEDNAR, D.A. Defining quality: alternatives and implications. Academy of Management Review, v.19, n.3, p.419 - 445, 1994.

RIBEIRO, A.R.; SAVASTANO Jr, H.; ABLAS, D.S. Avaliação do desempenho operacional e econômico de máquinas para fenação: cultura de CoastCross. Boletim da Indústria Animal, Nova Odessa, v. 56, n.2, p. 147-151, 1999.

ROTHERY, B. ISO 9000: Manual de qualidade para produtores. São Paulo: Makron Books, 1993. 270 p.

ROTZ, C.A., MUCK, R.E., Changes in forage quality durind harvest and storage. In: FAHEY JUNIOR, G.C. Forage quality, evaluation and utilization. Madison: ASA, CSSA, SSSA, 1994. p. 828-868. 
SARRIÉS, G.A., Controle estatístico da qualidade para impurezas minerais em carregamentos de cana de açúcar. Piracicaba, 1997. 83 p. Tese (Doutorado) - Centro de Energia Nuclear na Agricultura, Universidade de São Paulo.

SCHIERZ, A.B.F., Diagnóstico do padrão de qualidade de operações agrícolas mecanizadas em um sistema de produção de milho (Zea mays L.). Piracicaba, 1999, 44 p. Monografia (Graduação) - Escola Superior de Agricultura "Luiz de Queiroz", Universidade de São Paulo.

SEIFFERT, N.F. Produção de feno com forrageiras de verão. Informe Agropecuário, v. 6, n. 64, abr. 1980. p. 8-11.

SIEWERDT, L. Mecanização eficiente na produção de feno. Informe Agropecuário, v.6, n.64, abr. 1980. p. 23-28.

SERVIÇO NACIONAL DE APRENDIZAGEM INDUSTRIAL, Controle da qualidade - CEP: controle estatístico do processo. São Paulo: SENAI, 1987. $270 \mathrm{p}$.

SENTELHAS, P.C.; PEREIRA, A.R.; MARIN, F.R.; ANGELOCCI, L.R.; ALFONSI, R.R.; CARAMORI, P.H.; SWART, S., Banco de dados: Balanços hídricos climatológicos do Brasil (compact disc)/ Piracicaba: ESALQ, Departamento de Meteorologia, 1999.

SILVA, S.C.; PASSANEZI, M.M; CARNEVALLI, R.A.; PEDREIRA, C.G.S.; FAGUNDES, J.L., Bases para o estabelecimento do manejo de Cynodon sp. para pastejo e conservação. In: SIMPÓSIO SOBRE MANEJO DA PASTAGEM, 15., Piracicaba, 1998. Anais. Piracicaba: FEALQ, 1998. p. 129-150. 
STEVEN, M.D.; MILAR, C. Satellite monitoring for precision farm decision support. In: INTERNATIONAL CONFERENCE ON PRECISION FARMING, 3. , Minneapolis, 1996. Procedings. Madision: ASA, CSSA, SSSA, 1999. p. 225-237.

THYLÉN, A.; SUNDBERG, M., Simulation of mat hay-harvesting with six years of weather data. Journal of Agricultural Engineering Research, v. 60, p. 249-259, 1994.

TRINDADE, C.; REZENDE, J.L.P.; JACOVINE. L.A.G.;SARTORIO, M.L. Ferramentas da qualidade: aplicação na atividade florestal. Viçosa: Universidade Federal de Viçosa, 2000. 124p.

VEIGA, C.M., Modelo empírico para a seleção de máquinas agrícolas na cultura da soja considerando a pontualidade na semeadura. Piracicaba, 2000. 86 p. Dissertação (Mestrado) - Escola Superior de Agricultura "Luiz de Queiroz", Universidade de São Paulo.

VICINO S.R. Qualidade total. Piracicaba: Escola Superior de Agricultura "Luiz de Queiroz", Universidade de São Paulo. http://www.esalq.usp.br/qualidade (12 set. 2000).

VIEIRA, S. Estatística para a qualidade. Rio de Janeiro: Campus, 1997. 472 p.

VIEIRA, S., Estatística para a qualidade: como avaliar com precisão a qualidade em produtos e serviços. Rio de Janeiro: Campus, 1999. 198 p.

WITNEY, B. Choosing and using farm machines. Edinburgh: Land Techonology, 1988. 412 p. 